\title{
Geohydrology and \\ Water Resources of the Tucson Basin, Arizona
}

GEOLOGICAL SURVEY WATER-SUPPLY PAPER 1939-E

Prepared in cooperation with the city of Tucson, the U.S. Bureau of Reclamation, and the

University of Arizona

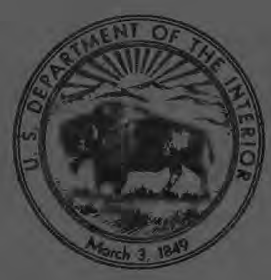




\section{Geohydrology and Water Resources of the Tucson Basin, Arizona}

By E. S. DAVIDSON

WATER RESOURGES OF THE TUGSON BASIN

GEOLOGICAL SURVEY WATER-SUPPLY PAPER 1939-E

Prepared in cooperation with the city of Tucson, the U.S. Bureau of Reclamation, and the

University of Arizona

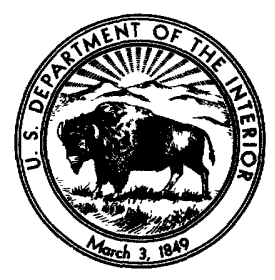




\section{UNITED STATES DEPARTMENT OF THE INTERIOR}

ROGERS C. B. MORTON, Secretary

\section{GEOLOGICAL SURVEY}

V. E. McKelvey, Director

Library of Congress catalog-card No. 72-600283

For sale by the Superintendent of Documents, U.S. Government Printing Office Washington, D.C. 20402 - Price $\$ 6.40$

Stock Number 2401-02390 


\section{CONTENTS}

\begin{tabular}{|c|c|}
\hline \multicolumn{2}{|l|}{ Abstract... } \\
\hline Introduction.. & 2 \\
\hline Location... & 4 \\
\hline Scope......... & 4 \\
\hline 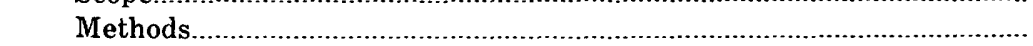 & 5 \\
\hline 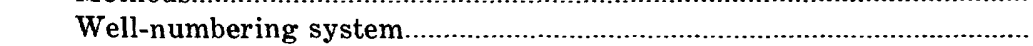 & 7 \\
\hline 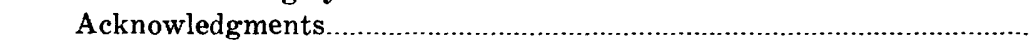 & 7 \\
\hline Hydrologic system & 9 \\
\hline Geohydrologic characteristics of the basin......................... & 11 \\
\hline Rock units along the margin of the basin........... & 13 \\
\hline Sedimentary units in the basin & 15 \\
\hline Pantano Formation. & 16 \\
\hline 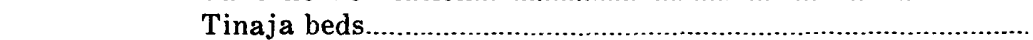 & 20 \\
\hline 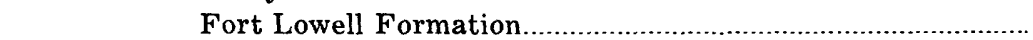 & 25 \\
\hline Surficial deposits & 30 \\
\hline Structure of sedimentary units in the basin..... & 33 \\
\hline Hydrologic characteristics of the aquifer system & 36 \\
\hline 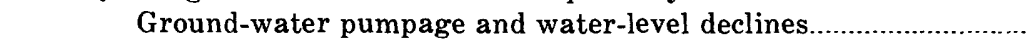 & 37 \\
\hline Relation between hydraulic head, lithology, and faults................. & 42 \\
\hline Transmissivity & 44 \\
\hline Relation of transmissivity to ground-water movement......... & 45 \\
\hline Areal and vertical reliability of the transmissivity pattern & 46 \\
\hline Storage & 48 \\
\hline 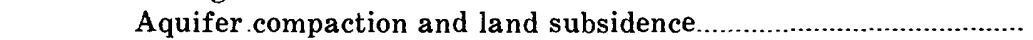 & 51 \\
\hline Streamflow & 54 \\
\hline 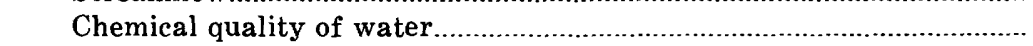 & 56 \\
\hline 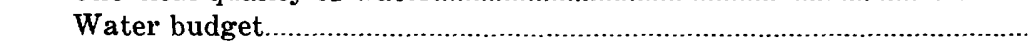 & 59 \\
\hline Aquifer recharge................ & 60 \\
\hline 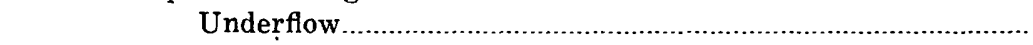 & 60 \\
\hline 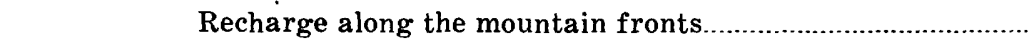 & 61 \\
\hline Streamflow infiltration and recharge & 62 \\
\hline Irrigation, sewage, and industrial return water......................... & 66 \\
\hline Discharge from the basin & 68 \\
\hline 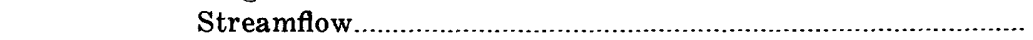 & 69 \\
\hline 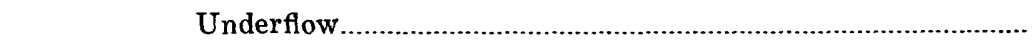 & 69 \\
\hline 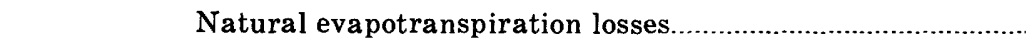 & 70 \\
\hline 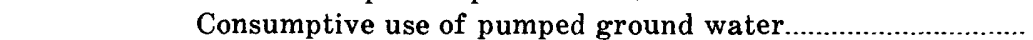 & 71 \\
\hline Budget summary & 72 \\
\hline lary & 72 \\
\hline References cited........ & 75 \\
\hline Index & 79 \\
\hline
\end{tabular}




\section{ILLUSTRATIONS}

[Plates are in separate map case]

Plate 1. Geohydrologic map, Tucson basin.

2. Geohydrologic sections, Tucson basin.

3. Map showing topography of the upper Santa Cruz River basin and boundary of area of investigation.

4. Hydrologic maps of the Tucson basin.

5. Map showing gravity anomaly and major faults in the Tucson basin.

6. Maps showing quality of ground water in the Tucson basin.

7. Schematic diagram showing major components of the natural annual water budget for the Tucson basin.

Figure 1. Map showing area of report

2. Diagram showing well-numbering system in Arizona

3. Graphs showing population, pumpage, and May through October precipitation

\section{TABLES}

TABLE 1. Relation between the depth below land surface and the hydraulic head in wells.

2. Frequency of discharge and flow rate for the Santa Cruz River and for Rillito, Rincon, and Sabino Creeks and Pantano Wash, 1936-63.

3. Mean annual infiltration volumes along the Santa Cruz River and its tributaries, 1936-63. 


\title{
WATER RESOURCES OF THE TUCSON BASIN
}

\section{GEOHYDROLOGY AND WATER RESOURGES OF THE TUCSON BASIN, ARIZONA}

\author{
By E. S. Davidson
}

\begin{abstract}
The major source of water in the Tucson basin is the vast volume of ground water in storage in the aquifer underlying the basin. Ground water is pumped for irrigation, public supply, and industrial uses and is partially replenished by the infiltration of streamflow along the major streams and the basin perimeter.

The basin is in southeastern Arizona and is a broad northwest-trending valley arcuately bounded by mountain ranges on the eastern and western sides. The 1,000-square-mile basin is about 50 miles long and is 15 to 20 miles wide in the southern and central parts and 4 miles wide at the northwest outlet. The surface of the basin slopes northwestward from an altitude of about 3,500 feet at the southern edge to an altitude of about 2,000 feet at the northwestern edge. The mountains on the west side of the basin range from 3,000 to 6,000 feet in altitude, and those on the east side range from 6,000 to 8,000 feet in altitude.
\end{abstract}

The mean annual precipitation is only about 12 inches on the basin surface and 25 inches or slightly more in the mountains. Because most of the precipitation is evaporated or transpired, the mean annual streamflow past gaging stations on the major streams is only about 10,000 to 20,000 acre-feet. The major streams generally are dry during more than 300 days each year, and the flows generally last 3 days or less. Because of the erratic occurrence and quantity of flow, streamflow is not used directly as a water supply. The mean annual streamflow out of the basin is slightly more than 17,000 acrefeet.

The aquifer that underlies the basin surface consists of the Pantano Formation and Tinaja beds of Tertiary age and the Fort Lowell Formation and surficial deposits of Quaternary age. These units are more than 2,000 feet thick and are composed mainly of loosely consolidated to moderately cemented silty sand to silty gravel. In the south-central part of the basin and in a small area in the northern part, a thick section of clayey silt to mudstone fills a structural depression caused by downfaulting of the Pantano Formation and the older units.

The chemical quality of the ground water in most of the basin is suitable for public supply. Most of the water in the upper part of the aquifer contains less than $500 \mathrm{mg} / 1$ (milligrams per liter) dissolved solids, and in most of the area the range in dissolved-solids content is from 250 to $1,500 \mathrm{mg} / \mathrm{l}$; in 
a few isolated places concentrations as great as $3,000 \mathrm{mg} / \mathrm{l}$ occur. The dissolved solids are mainly calcium, sodium, and bicarbonate. Ground water in the northern and northeastern parts of the basin generally contains less than $300 \mathrm{mg} / 1$ dissolved solids and is moderately hard; elsewhere the dissolved-solids content generally ranges from 300 to $500 \mathrm{mg} / 1$, and the water is hard. In the deep part of the aquifer the water generally contains less than $500 \mathrm{mg} / 1$ dissolved solids, mainly sodium and bicarbonate, and is soft; but where the aquifer grades into clayey silt or mudstone, the water may contain more than $2,000 \mathrm{mg} / \mathrm{l}$ dissolved solids, mainly sodium, calcium, and sulfate, and the water is hard. Fluoride and chloride also are more common in water from the deep part of the aquifer than in water from the upper part.

The amount of ground water in storage to a depth of 500 feet below the 1966 water table was about 30.5 million acre-feet, and that to a depth of 1,000 feet below the water table was about 52 million acre-feet. Less than 2 million acre-feet of water was withdrawn from storage in 1940-65. In most of the basin, the depth to water in 1966 was 50-100 feet below the land surface along the major streams to about 500 feet below the land surface in the eastern part of the basin.

Transmissivity values for the aquifer average about 50,000 gallons per day per foot and range from 1,000 to almost 500,000 gallons per day per foot. Most large-diameter wells yield 5-100 gallons per minute per foot of drawdown and are pumped at rates of 500-1,500 gallons per minute.

The mean annual recharge to the aquifer from underflow and from infiltrated streamflow along streams and the basin perimeter was about 100,000 acre-feet in the period 1936-63. The total pumpage was about 177,000 acrefeet in 1965. Owing to natural recharge and return of pumped water, about 85,000 acre-feet of ground water was removed from storage in 1965.

\section{INTRODUCTION}

The Tucson basin is a broad alluvial valley bounded by rugged mountain ranges in southeastern Arizona (fig. 1). The combination of low altitude, year-round warm temperatures, sunny days, and scant rainfall effect an attractive livable climate. The agricultural areas are very productive where water and irrigable land are ample. The city of Tucson, which had a population of about 235,000 in 1965, is in the northern part of the basin, and the irrigated land is along the Santa Cruz River northwest and south of Tucson. The climate is semiarid; the potential evaporation is great, and precipitation and streamflow are too scarce to be dependable as a source for public water supplies or for irrigation of crops. The water source is an aquifer underlying the basin surface which permits large well yields and which stores a large quantity of water. In 1965 about 177,000 acre-feet of water was pumped from the aquifer; about 60 percent was used for irrigation, about 30 percent for public supply, and about 10 percent for industry. The aquifer comprises several sedimentary formations which underlie the basin surface to depths greater than 2,000 feet. In contrast to the detrital deposits in the basin, the rocks of the 


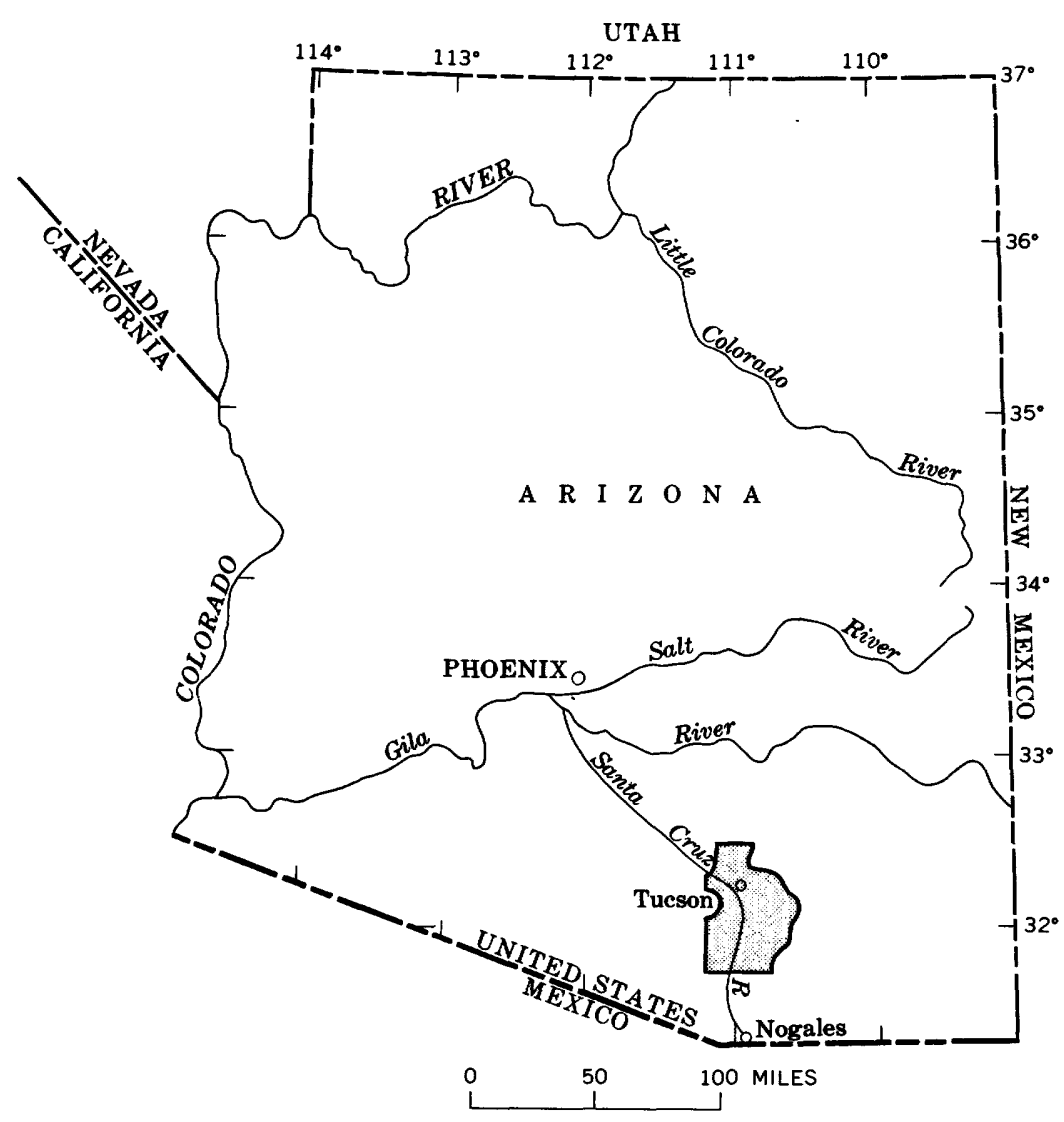

FIGURE 1. - Area of report (shaded).

bounding mountain ranges are so relatively impermeable and nonporous that well yields and ground-water storage per unit volume of rock are small.

The study of the water resources in the Tucson basin was prompted by a need for comprehensive knowledge that would aid in water management. The purpose of the study was to describe the general hydrologic system of the area, to describe, in detail, selected parts of the system, and to describe the quantity and quality of the water resources that can be made available for man's use. Additionally, some of the historical and predicted effects of using water in the area were documented in this study.

This report summarizes the results of a 3-year investigation, 1966 through 1968, of the primary factors that control the distribution, volume, and quality of the water resources and that control the effects of ground-water withdrawal in the Tucson basin. The 
purpose of this report is to summarize the results of the entire study with special emphasis on the geohydrology and water budget of the basin. The report is intended for use by administrative and technical professionals in hydrology, water management, and geology and by an informed lay public.

The Tucson basin study was undertaken by the U.S. Geological Survey in cooperation with the city of Tucson, the U.S. Bureau of Reclamation, and the University of Arizona. The investigation was conducted under the immediate supervision of H. M. Babcock, district chief of the Water Resources Division of the U.S. Geological Survey in Arizona.

\section{LOCATION}

The Tucson basin is a broad 1,000-square-mile area in the upper Santa Cruz River drainage basin. The Tucson basin is bounded on the east and north by the Santa Rita, Empire, Rincon, Tanque Verde, Santa Catalina, and Tortolita Mountains and on the west by the Sierrita, Black, and Tucson Mountains (pl. 3). The mountains on the east and north generally are at altitudes of 6,000 to 8,000 feet, and the peaks reach altitudes of as much as 9,400 feet; the mountains on the west are 3,000 to 6,000 feet in altitude. The area is drained to the northwest by the Santa Cruz River and its principal tributaries-Rillito Creek, Pantano Wash, and Canada del Oro (pl. 3). This stream system has formed a gently northwest-sloping plain, which is at altitudes of about 2,900 feet in the south and 2,000 feet at the northwest outlet. The basin is 15 to 20 miles wide in the southern and central parts and narrows to 4 miles at the northwest outlet; it is about 50 miles long.

As used in this report, the term "basin" refers to the topographic area below the base of the precipitous mountain slopes. In most places along the base of the mountains the change in slope, or inflection point, is also the contact between the stream-laid detritus of the basin and the resistant rock of the mountains. The report area includes the basin and much of the bordering mountain ranges (pls. 1 and 3). In the valleys between the mountains the area boundary was arbitrarily selected along latitude $31^{\circ} 45^{\prime} \mathrm{N}$. in the southern part of the area, lat $32^{\circ} 30^{\prime} \mathrm{N}$. in the Canada del Oro valley, and lines of shortest distance between mountain masses for other segments of the perimeter. The streamflow phase of the study includes the entire drainage area of the Santa Cruz River upstream from Rillito, Ariz. (pl. 3).

\section{SCOPE}

This report describes the hydrologic system in the Tucson basin area with emphasis on the geology and its control on water-level 
declines, aquifer transmissivity and well yields, chemical quality of the water, and ground-water recharge and storage. The results of the entire study are summarized in this report, and where data are not singular enough to allow one interpretation, alternate possible solutions and potential errors are discussed. Detailed discussions of the different phases of the investigation, which was designed to provide data for effective water use and management, are contained in other chapters of Water-Supply Paper 1939. The salient facts or interpretations contained in these other chapters are included in this report to show their interrelation and to appraise their importance in regard to the entire hydrologic system.

The description of the geohydrologic system is the principal contribution of this chapter; knowledge of the system aided particularly in the evaluation of the electrical-analog analysis, which was used to derive the aquifer water budget and to support the calculation of ground-water storage. Distribution of the sedimentary facies, location of faults that offset the facies, cause and effect relation between the faults and offsets of the facies, anomalous water temperatures, chemical quality of ground water, groundwater movement, and well yields are discussed in this chapter. The first topic discussed in this chapter is the geohydrologic characteristics of the basin, followed by quantitative and qualitative discussions of the hydrologic characteristics of the aquifer, ground water, and streamflow; the chapter is concluded with an account of the water budget.

\section{METHODS}

In the appraisal of the water resources of the Tucson basin, particular emphasis was placed on data for immediate input to the electrical-analog model and for practical use in water development. The analog model was used to estimate some of the quantitative ground-water flow through the aquifer by using water-level and transmissivity data as constraints; the model was also used to predict water-level changes for different hypothetical schemes of pumping. Analyses of streamflow and streamflow infiltration provided estimates of the maximum ground-water recharge along the major streams. Geologic study aided in the construction of an analog model representative of the hydrologic system and indicated the sources of many anomalous variations in the chemical quality of the ground water. Chemical properties of the water resources were analyzed to determine the source and distribution of the type and quality of water throughout the basin. If data were not available for a phase of the project, reasonable estimates 
were used in the analyses until more accurate quantities or interpretations could be provided.

Water-level and chemical-quality-of-water data were available from the reports and files of the Agricultural Engineering Department of the University of Arizona and from those of the U.S. Geological Survey. Streamflow measurements made by the U.S. Geological Survey in the upper Santa Cruz River basin were analyzed statistically ; the resultant streamflow-frequency computations were used to estimate streamflow infiltration by the application of an empirically derived relation between streamflow rates and infiltration rates. Ground-water pumpage was compiled or estimated. Short-term aquifer tests were conducted at as many wells as possible to obtain transmissivity values of the aquifer. The most intense coverage was about one well per square mile; several dozen wells were retested to confirm previous tests or preexisting records.

Fieldwork in the early stages of the project was limited to providing answers to questions concerning streamflow infiltration, water quality, water-temperature anomalies, or other related information needed for electrical-analog-model construction. In the later stages of the project many additional water-level measurements were made near the perimeter of the aquifer, and quantitative size analyses and geophysical well logs were examined as an aid in the evaluation of the analog model and the preliminary geologic interpretations. Reconnaissance geologic mapping was done only in places where existing data were too generalized to be useful in the quantitative survey of the water resources. The distribution and structure of the rocks that crop out near the basin perimeter were generalized from published reports and maps (pl. 1), and the surficial distribution of the sedimentary units was generalized from other reports. Most of the geologic work of this investigation was with the subsurface structure and stratigraphy of the sedimentary units.

The city of Tucson drilled three test holes to depths of 1,800 to 3,000 feet, and the Bureau of Reclamation drilled six test holes to depths of 500 to 1,900 feet. Drill-cutting samples at 10-foot intervals and cores at selected intervals were taken in the basin detritus. The test holes drilled by the city were sealed by inflatable packers and were air-line pumped from selected intervals to produce water for chemical analysis. The holes drilled by the Bureau of Reclamation were fitted with 11/4-inch-internal-diameter piezometer tubes inserted in a coarse gravel-packed interval sealed at either end by a concrete plug. Water for chemical analysis was forced to the surface through the tubes by compressed air. Water 
levels also were measured in the test wells. The city of Tucson drilled several test production holes to obtain additional geologic and hydrologic data. Sample cuttings have been collected from many hundreds of water wells by personnel of the University of Arizona and the U.S. Geological Survey in the past two decades. The collection program was intensified in 1962-68, and the mechanical size analyses of samples from wells throughout the basin have provided invaluable aid in delineating the structure and stratigraphy of the aquifer.

\section{WELL-NUMBERING SYSTEM}

The well numbers used by the U.S. Geological Survey in Arizona are in accordance with the Bureau of Land Management's system of land subdivision (fig. 2). The land survey in most of Arizona is bašed on the Gila and Salt River meridian and base line, which divide the State into four quadrants. These quadrants are designated counterclockwise by the capital letters A, B, C, and D. All land northeast of the point of origin is in A quadrant, that northwest in B quadrant, that southwest in C quadrant, and that southeast in $\mathrm{D}$ quadrant. The first digit of a well number indicates the township, the second the range, and the third the section in which the well is situated. The lowercase letters $a, b$, c, and $d$ after the section number indicate the well location within the section. The first letter denotes a particular 160 -acre tract, the second a 40 -acre tract, and the third a 10-acre tract. These letters also are assigned in a counterclockwise direction, beginning in the northeast quarter. If the location is known to within the 10-acre tract, three lowercase letters are shown in the well number. In the example shown (fig. 2), well number (D-4-5) 19caa designates the well as being in the $\mathrm{NE}_{1 / 4} \mathrm{NE}_{1 / 4} \mathrm{SW}_{1 / 4}$ sec. 19 , T. $4 \mathrm{~S}$., R. $5 \mathrm{E}$. Where there is more than one well within a 10 -acre tract, consecutive numbers beginning with 1 are added as suffixes.

\section{ACKNOWLEDGMENTS}

During the water-resources investigation of the Tucson basin, cooperation was received from many employees of the city of Tucson and Pima County governments, the Bureau of Reclamation, and the University of Arizona. The author is particularly grateful for the assistance given by Paul Beerman, former director, and F. E. Brooks, current director of Water and Sewer Systems; J. F. Rauscher, former chief engineer; and M. E. Devine, superintendent of the Production Division-all employees of the city of Tucson Water Department. Personnel of the Bureau of Reclamation aided in test drilling and aquifer testing, and E. E. Komie kindly read the report and offered helpful suggestions. 
B
A

C

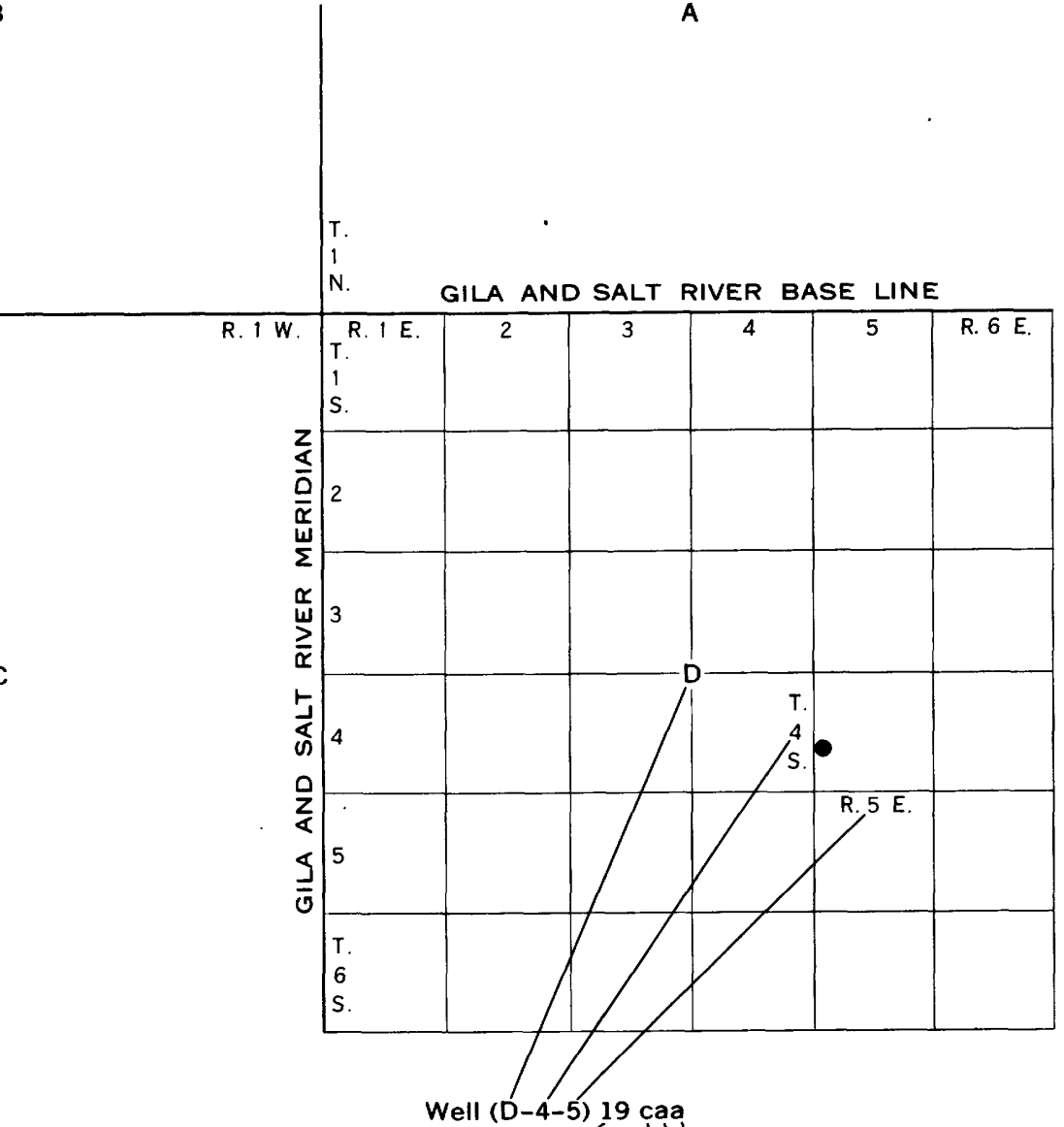

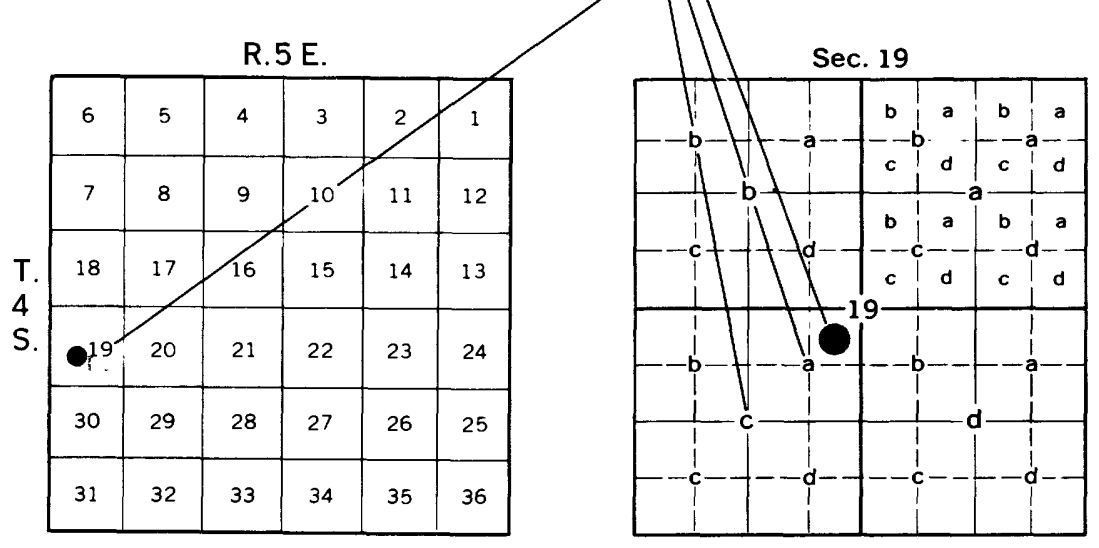

Figure 2. - Well-numbering system in Arizona. 
The aquifer tests were supervised and scheduled by W. G. Matlock, Wayne Clyma, and R. J. Shaw of the Agricultural Engineering Department of the University of Arizona, and their very necessary work is appreciated; H. C. Schwalen, also from the Agricultural Engineering Department, furnished data and well-cutting samples, which he had collected in the past decade. Well drillers, who were very helpful in taking the trouble and time to collect well-cutting samples, were A. A. McDaniel, A. L. Cotton Boring, C. W. Pistor, Cecil Banghart, Buck Weber, Buckingham Drilling Co., and Layne Texas Co.; their contributions to this study are gratefully acknowledged. Many of the U.S. Geological Survey staff helped in data collection and in technical discussions, and S. G. Brown rendered more than usual assistance in collecting, plotting, and compiling data for this investigation.

\section{HYDROLOGIC SYSTEM}

All the water in the upper Santa Cruz River drainage basin (pl. 3) originates as precipitation, and most of the precipitation evaporates or is transpired by plants. Some of the precipitation becomes direct runoff and streamflow, and although some of this water flows out of the basin, most of it infiltrates to the groundwater reservoir. The largest part of the outflow from the groundwater reservoir is pumped and consumed; smaller amounts naturally evaporate, transpire, or slowly drain from the basin at the northwest outlet. The parts of the hydrologic system that are most significant to the purpose of this investigation are ground water in storage, surface-water and ground-water inflow and outflow, and outflow by evaporation, by transpiration, and by consumption of pumpage.

The dominant part of the hydrologic system is the vast amount of water in storage in the thick sedimentary detritus that underlies the basin. Most of the stored water is of good chemical quality. Ground water moves very slowly northwestward, parallel to the surface drainage of the basin, toward the subsurface outlet at Rillito; in comparison with the amount of inflow and the amount of water in storage, a relatively small amount leaves the upper Santa Cruz River drainage basin.

Streamflow, evaporation, and transpiration outflow from the basin was equal to inflow prior to 1900 , and ground-water storage was approximately constant. Surface runoff prior to extensive habitation of the basin was probably greater than that in recent years, because ground water was then discharged locally as streamflow and spring flow (Smith, 1910, p. 98). Also, ground- 
water loss through evapotranspiration was probably greater because the water table was at or near land surface and because marshes were present along the Santa Cruz River (Hastings, 1958, p. 29). The system has been altered (Smith, 1910; Hastings, 1958), and most of the streamflow now infiltrates to the groundwater reservoir; because of the increased depth to water, natural uncontrolled evaporation and transpiration are much less significant in the water cycle now than they were in the late 1800 's. For example, in the 1960's a dense growth of mesquite in a few hundred acres upstream from Sahuarita Butte died because the depth to water had increased beyond the reach of the plant roots. In the past half a century, the decrease in evaporation and transpiration probably has been continuous, owing to a steadily increasing use of pumped water.

The depth to ground water is least along the Santa Cruz River and in the northern part of the basin and is greatest in the southeastern part (pl. $4 A$ ). Along the Santa Cruz River and Rillito Creek, ground water is within 100 feet of the land surface, and along some reaches it is within 50 feet of the land surface; along Canada del Oro and Pantano Wash, however, the water level is 100 to 250 feet below the land surface. Along much of Tanque Verde Creek, Sabino Creek, and Agua Caliente Wash, ground water is less than 25 feet below the land surface, and small springs and seeps still exist along these streams. In the central part of the Tucson urban area, water is 100 to 250 feet below the land surface, and the depth to water increases gradually to about 700 feet near the north end of the Santa Rita Mountains (pl. 4A). Groundwater levels are declining at average rates of 1 to 2 feet per year along the major streams and 2 to 4 feet per year in the urban Tucson area (Matlock and others, 1965); the decline is in response to the imbalance between ground-water inflow and ground-water withdrawal.

Precipitation in the upper Santa Cruz River drainage basin (Green and Sellers, 1964, p. 9-21) is controlled mainly by altitude; the average annual precipitation is 11-12 inches in the central part of the basin and increases to 25 inches or more at altitudes above 7,500 feet. About 65 percent of the precipitation falls between May and October, and 50 percent of the total falls in July and August. Most of the precipitation in July, August, and September occurs during convective thunderstorms, which precipitate moisture blown in from the Gulf of Mexico. The precipitation is localized, showery, and intense over mountainous terrain and normally light over desert terrain (Green and Sellers, 1964, p. 13). The precipitation density during the thunderstorms is moderate 
on a daily basis but may be intense on an hourly basis (Condes de la Torre, 1970; Burkham, 1970). Occasional tropical storms move inland from the Gulf of California and the Pacific Oceanmost frequently in late August and September-and precipitate large amounts of rain over much of the State. In the winter, precipitation is from cyclonic storms that originate to the northwest and move eastward across the Nation; it is widespread and light to moderate in intensity.

The greatest average monthly precipitation occurs in the summer, when the air temperature is highest and the potential evapotranspiration is greatest. The average monthly temperature at Tucson ranges from $50^{\circ} \mathrm{F}$ in January to $86^{\circ} \mathrm{F}$ in July (Green and Sellers, 1964, p. 435). Because of the high temperatures and semiarid climate in the Tucson basin, the annual potential evapotranspiration-computed by the Thornthwaite method (Thornthwaite, 1948) -is about 42 inches per year (Buol, 1964, p. 8), or four times the average annual precipitation.

Mainly owing to evapotranspiration, only 0.6 percent of the precipitation into the Santa Cruz River drainage upstream from Tucson and 1 percent of the precipitation into the drainage of Rillito Creek flow past Tucson (Schwalen, 1942, p. 468-469). The average annual runoff ranges from about 3 acre-feet per square mile ( $0.056 \mathrm{in}$.) in the central part of the basin, where infiltration is great, to more than 200 acre-feet per square mile (3.8 in.) in the mountainous areas (Burkham, 1970; Condes de la Torre, 1970), where infiltration is slight.

The average annual streamflow out of the basin at Rillito was about 17,000 acre-feet during the base period 1936-63. Typical of semiarid and arid lands, the standard deviation of the annual flow at most gaging stations in the area is about as large or larger than the mean annual flow, which indicates the instability of the flow source. Because of the great variability in flow and the lack of surface storage reservoirs, almost no runoff is used for irrigation or public supply. The amount of streamflow infiltrated to the ground-water reservoir is more critical to the water resources of the Tucson area than is the surface volume of streamflow. The average annual infiltration along the main stream channels of the basin is about 51,000 acre-feet; almost 75 percent of the surface water that flows into the main stream channels infiltrates within the confines of the basin.

\section{GEOHYDROLOGIC CHARACTERISTICS OF THE BASIN}

The principal function of the rock units in the hydrologic system is the storage of ground water. The hydrologic utility of the rock units is dependent on their ability to store and transmit 
water to wells and springs without deleteriously affecting the chemical quality of the water. These roles are dependent primarily on the amount of void space in the rock, the size of the voids and the degree of interconnection between them, the solubility of the rock materials in water, and the residence time for water in the rocks. The relative amount of void space in a rock, or porosity, usually is expressed as a percentage of the bulk volume. Porosity is described as low if it is estimated to be less than 10 percent, moderate if it is estimated to be 10 to 20 percent, and high if it is estimated to be greater than 20 percent. Only part of the water that is stored in the voids will drain into a well or other collection device; the volume of water that can be obtained from an aquifer is expressed as the coefficient of storage, which is the volume of water the aquifer releases from or takes into storage per unit surface area of the aquifer per unit change in head. The void size and interconnection most influence the permeability, which is a measure of the ability of the rock to transmit water. In this report, the permeability measure, in meinzer units, is the flow in gallons per day through a square foot of aquifer under a hydraulic gradient of 100 percent $\left(\frac{\text { gallons }}{\text { day } / \mathrm{ft}^{2}(\mathrm{ft} / \mathrm{ft})}\right)$. Permeability is described as low if it is estimated to be less than 10 meinzer units, moderate if it is estimated to be 10 to 100 meinzer units, and high if it is estimated to be greater than 100 meinzer units.

A secondary function of the rock units in the hydrologic system is the support of vegetation and a thick soil cover. A discussion of this function is beyond the scope of this investigation; in general, more runoff will result from precipitation on areas that are sparsely vegetated and underlain by dense rock covered by thin soil than from areas that are thickly vegetated and covered by thick soil.

All the rock units in the Tucson basin area are capable of storing and yielding water to wells or springs; however, the capability ranges widely from unit to unit and within a single unit from place to place. The units that bound the basin and form the mountains are mainly igneous, metamorphic, and tightly cemented sedimentary rocks, which transmit and store smaller quantities of water than do the more porous and permeable loosely consolidated sedimentary rocks of the basin. The rock units (pl. 1) are differentiated primarily on the basis of age rather than lithology because the older rocks generally are more dense and cemented and less porous and permeable than are the younger rocks. The rock units are grouped also on the basis of origin. The intrusive and most of the metamorphic rocks are the least permeable and 
porous and contain water only in fractures. The volcanic rocks vary greatly in porosity and permeability from place to place; generally, the oldest volcanic rocks contain significant quantities of water only in fractures, but the youngest volcanic rocks may store and yield water as readily as some sedimentary rocks. The sedimentary rocks are several thousands of feet thick and have the highest degree of porosity and permeability; wells developed in these rocks will yield large quantities of water. The younger sedimentary rocks store and transmit the largest quantities of ground water per unit volume.

\section{ROCK UNITS ALONG THE MARGIN OF THE BASIN}

The rock units that crop out along the margin of the Tucson basin consist of nonporous crystalline intrusive and metamorphic rocks, slightly porous to highly porous volcanic and interbedded sedimentary rocks, and slightly porous to moderately porous sedimentary rocks. The least porous units are the least permeable and the most resistant; these rocks form the mountain ranges and the bottom of the sediment-filled basin and restrict the flow of ground water into or out of the basin.

The Santa Catalina, Rincon, and Tortolita Mountains are composed of metamorphic and intrusive igneous rocks and are the largest mass of low-porosity and low-permeability material bounding the Tucson basin. The Sierrita, Santa Rita, and Empire Mountains are composed mainly of low to moderately permeable sedimentary, metamorphic, and intrusive igneous rocks. The Tucson Mountains are formed mainly by low-permeability volcanic rocks, but the northern and eastern slopes of the Tucson Mountains and Black Mountain are underlain by volcanic and sedimentary rocks that are moderately permeable and porous. Wells drilled in rocks of the mountains generally have low yields and furnish adequate water only to small ranches, homes, and stock.

The crystalline intrusive and metamorphic rocks, which contain water only along fractures, are mainly granodioritic gneiss and granite but include lesser amounts of felsic to mafic schist and several types of felsic intrusives. The oldest crystalline rocks are Precambrian and the youngest are late Tertiary. Where the rock is fractured and where rainfall or streamflow are sufficient and frequent enough to provide recharge, wells will yield a few gallons per minute of water for stock or residential use. Many of the springs at the base of the Santa Catalina and Rincon Mountains are fed by rain and snowmelt that are transmitted by fractures through the granodioritic rocks and forced to the surface at the contact between the fractured crystalline rock and the tightly cemented sedimentary rock downgradient from the spring 
(Pashley, 1966, p. 56-59). Springs in the higher parts of the Rincon, Santa Catalina, and Tortolita Mountains are fed by water moving through fractures, and the permanence and amount of their flow are dependent on the extent of the fracture system and on the frequency and amount of precipitation. The water in the crystalline rocks is generally potable, but in some places along the base of the Santa Catalina and Rincon Mountains it contains objectionable amounts of dissolved iron. The water from some of the springs contains large amounts of dissolved solids (Laney, 1972) and is not very suitable for public supply or watering lawns without treatment.

The largest masses of volcanic rocks are in the Tucson, Black, and Sierrita Mountains, where the rocks consist of andesitic to rhyolitic flows, tuff, and agglomerate and minor amounts of interbedded conglomerate and sandstone. The older volcanic rocks are Mesozoic to middle Tertiary and generally have low to moderate porosity and low permeability. Most springs and wells in the older volcanic rocks yield only small amounts of water, but the water generally is of good chemical quality. In some places water is in beds of low-permeability material-such as tuff, weakly cemented sedimentary rocks, or slightly open fragmental or vesicular lava flows; but the permeability may be enhanced locally by fractures. In other places water is only in fractures. Many wells along the western part of the basin tap saturated sedimentary rocks and terminate in the underlying older volcanic rocks at depths of several hundred to a thousand feet or more; the volcanic rocks generally are hard and dense and probably yield only small amounts of water to the wells.

The younger volcanic rocks of middle to late Tertiary age crop out dominantly on Black Mountain and on the eastern slopes of the Tucson Mountains. They are somewhat more vesicular and fractured, and thus more porous and permeable, than the older volcanic rocks, and the intercalated beds of sediment are not as well cemented as sediment interbedded with the older volcanic rocks. The younger volcanic rocks are above the water table in most places but are tapped by a few wells in and near the Tucson Mountains. The water generally is of good chemical quality and has a low dissolved-solids content.

Sedimentary rocks of low water-yielding capacity crop out in large areas of the Sierrita and Santa Rita Mountains. Most of the units are Mesozoic in age (Cooper, 1960a; Hayes and Drewes, 1968; Drewes and Finnell, 1968; and Drewes, 1968b, c), but small outcrops of Paleozoic rocks are included (pl. 1). The Paleozoic sedimentary rocks are mainly sandstone, claystone, siltstone, and 
conglomerate but include lesser amounts of limestone and quartzite. The sedimentary rocks of Mesozoic age include interbedded volcanic flows, tuff, and agglomerate. Most of the sedimentary rocks have low porosity and permeability, but some units have moderate to high porosity and permeability. Ground water in these rocks probably contains dissolved solids in amounts objectionable for public supply. A few wells in the basin penetrate tightly cemented conglomerate (pls. 1 and 2 , sections $E-E^{\prime}, F-F^{\prime \prime}$, $\left.I-I^{\prime}\right)$ that has been assigned to the Mesozoic sequence. The drillers' logs and the borehole geophysical logs of most of these wells indicate that the water-yielding potential of this sequence is poor. Although fractures supply small amounts of water to springs, particularly those that issue from the limestone and quartzite, in general the sedimentary rocks of Mesozoic and Paleozoic age act as a relatively impermeable barrier to the movement of ground water.

\section{SEDIMENTARY UNITS IN THE BASIN}

The sedimentary rocks in the basin form a single aquifer. The aquifer comprises the Pantano Formation (Finnell, 1970) and correlative sedimentary rocks of Tertiary age and overlying units of Tertiary and younger ages (pl. 1). The units have been distinguished because their hydrologic characteristics are different, and knowledge of each unit's areal occurrence is vital in guiding ground-water exploration and other water-supply ventures. The Pantano typically is a silty sandstone to gravel that crops out locally around the edges of the basin and has been penetrated by wells at depths of 1,500 feet or more in the center of the basin. The Pantano is overlain by the locally derived Tinaja beds, which were deposited in a basin of internal drainage. The beds consist of gravel and sand that grade into a very thick sequence of gypsiferous clayey silt and mudstone in the center of the basin. The Fort Lowell Formation is the youngest unit that was deposited in the basin of internal drainage. The Fort Lowell grades from gravel near the edges of the basin to silt in the center. Tilting, accompanied by minor faulting, ended the sedimentation of the Fort Lowell Formation and initiated erosion and the early stages of the present drainage system. As a result, relatively thin surficial deposits were laid down on erosional surfaces cut on older units; the alluvium along the present stream courses is the youngest and topographically lowest surficial deposit.

The sedimentary units have been differentiated on the basis of color, rock-fragment content, degree of cementation, and spatial position. As depth of burial increases, identification of the units becomes more tenuous, and age assignments and correlation 
become more uncertain. The most effective supplementary aid in discriminating units and in correlating them across the basin is a graphic plot of the percentage of sand and coarser material penetrated by wells. The examination and analysis of these plots and of the subsequently constructed structural contour maps, scaled cross sections, and vertically exaggerated cross sections (pl. 2) indicated the probability that major faults offset the older sedimentary units of the basin. The correlations suggested in this paper are based on geologic analysis of the facies variations and structural positions of the several formations in the basin. Although the formational distribution can be explained by solutions other than those suggested in this report, an effort was made to choose the solution that is most simple and straightforward.

\section{PANTANO FORMATION}

The Pantano Formation (Finnell, 1970) typically is a reddishbrown silty sandstone to gravel that is weakly to strongly cemented by calcium carbonate. The formation contains a few interbedded volcanic flows and tuffs and is correlative with sequences of volcanic rocks that crop out in some of the nearby mountains. Because of the lack of adequate drill-hole information, the Pantano Formation cannot yet be traced with certainty from one part of the basin to another. The Pantano is the least known part of the aquifer, and the assignment of various rock units to the Pantano is tentative. Because of its large volume and extent and its low to moderate permeability and moderate to high porosity, a knowledge of this unit is critical in regard to water-resources management. Deep drilling will be necessary to confirm the facies distribution and to determine the areal distribution of its water yield and storage potential.

The Pantano Formation and correlative sequences of sedimentary rocks yield only small amounts of water to shallow wells, but at depth the unit is a reasonably good aquifer. The Pantano and correlative Helmet Fanglomerate (Cooper, 1960a) and San Xavier conglomerate beds (Heindl, 1959, p. 154) form most of the aquifer west of the Santa Cruz fault and south of the Tucson Mountains (pls. 1 and 2, sections $E-E^{\prime}, F-F^{\prime \prime}, G-G^{\prime}, H-H^{\prime}$, and $I-I^{\prime}$ ). As used in this report, the Pantano also includes a sandstone aquifer tapped by wells in the central and eastern parts of the basin (pls. 1 and 2 , section $F-F^{\prime}$, wells (D-15-14) 3 dad and (D-15-14) 2dbc; section $E-E^{\prime}$, well (D-16-15) 10ccc) and a moderately cemented conglomerate penetrated in the northern part of the basin (pls. 1 and 2, section $A-A^{\prime}$, well (D-13-13) $3 \mathrm{cdb}$ ). The type locality of the Pantano is in the eastern part of the basin 
near Davidson Canyon (Brennan, 1957). Some of the outcrops in the foothills of the Santa Catalina and Tanque Verde Mountains that were mapped as Rillito I by Pashley (1966) are probably equivalent to the Pantano. The type section near Davidson Canyon has been mapped and redefined by Finnell (1970). The Pantano as defined by Finnell is used in this paper, but it is possible that Finnell's unit 5 of the Pantano is the lower part of the Tinaja beds of this report.

Volcanic flows interbedded in the Pantano Formation have been dated by the potassium-argon method. A distinctive andesite porphyry has an apparent age of about $27 \mathrm{~m} . \mathrm{y}$. (million years) (Percious, 1968, p. 202) where a dike and flow intrude and directly overlie the San Xavier conglomerate beds, and of about 28 m.y. (Damon and Bikerman, 1964, p. 69) at Sentinel Peak in the Tucson Mountains (pl. 1), where the flow is part of a volcanic sequence. A similar flow interbedded in the Pantano Formation near Davidson Canyon contains plagioclase dated at $24.4 \pm 2.6$ m.y. (Finnell, 1970, p. 36). Cooper (1960a) mapped similar flows interbedded in the middle part of the Helmet Fanglomerate of the Sierrita Mountains, where a closely associated tuff has an apparent age of about 28 m.y. (Damon and Bikerman, 1964, p. 70). A rhyolite ash flow at the base of the Pantano Formation (Finnell, 1970, p. 36) has an apparent age of about 33 to $37 \mathrm{~m} . \mathrm{y}$. (Damon and Bikerman, 1964, p. 69). The dates indicate that most of the Pantano is Oligocene in age-26 to 37-38 m.y. (Geological Society of London, 1964, p. 260-262). The Pantano is equivalent in age to the sequence of volcanic flows in the Tucson Mountains from the Rillito andesite (Brown, 1939) at the base (about 38 m.y.) to the upper andesite (Brown, 1939) at the top (about 28 m.y.) (Damon and Bikerman, 1964; Bikerman and Damon, 1966; Percious, 1968), perhaps including the thin conglomerate (Brown, 1939, p. 735-736 and pl. 1) that underlies the Rillito andesite. The Grosvenor Hills Volcanics (Drewes, 1968b, p. 14-15) that crop out in the Santa Rita Mountains (pl. 1) and some of the volcanic sequence (Taylor, 1960) in the Tumacacori Mountains also are equivalent to the Pantano Formation.

The Pantano Formation is at least 6,400 feet thick near Davidson Canyon (Finnell, 1970, p. 35), and the correlative Helmet Fanglomerate is about 10,500 feet thick in the Sierrita Mountain area (Cooper, 1960a, p. 87). The thickness of the Pantano Formation in the central part of the Tucson basin is not known, but a few hundred to about 1,000 feet of sediment is assigned to the unit (pls. 1 and 2). Well cores show that the unit is slightly inclined to flat in the center of the basin, despite the steep dips 
and complex structural involvement (Brennan, 1957; Cooper, 1960a; Pashley, 1966; Finnell, 1970) around the edges of the basin. In places, deep wells terminate in sediment or in volcanic rocks that probably are an older unit (pl. 2, sections $E-E^{\prime}, H-H^{\prime}$, and $I-I^{\prime}$ ), but in other places, similarly deep wells do not penetrate material sufficiently harder or lithologically dissimilar to warrant the suggestion of an older unit. At best, the selection and correlation of a basal contact in the wells are tenuous. The contact is more useful from a hydrologic viewpoint than from a geologic one because the older units shown in the cross sections are very tightly cemented and only slightly permeable. In fact, the conglomerate penetrated in the lower part of well (D-13-13) 3cdb (pl. 2, section $A-A^{\prime}$ ) is as tightly cemented as the Mesozoic units in other wells; it is correlated with the Pantano only because it contains detritus of volcanic rocks that I identify as Late Cretaceous to early Tertiary in age.

The Pantano is a light- to medium-reddish-brown silty and pebbly sandstone to moderately cemented gravel in the subsurface. In weathered exposures the formation is generally medium to dark reddish brown and is much more tightly cemented than in the fresh cores taken from wells. The formation contains granitic and diverse types of sedimentary and volcanic detritus in an arkosic to clay-rich sandy matrix. Typically, the formation contains rock fragments that are exotic to the area of outcrop, and it may contain few or no rock fragments from the area of outcrop. For example, the Pantano at the type locality and the probably equivalent Rillito I unit of Pashley (1966) at the base of the Rincon and Santa Catalina Mountains contain very little if any Catalina Gneiss (DuBois, 1959). This is true also of the other sequences assigned to the Pantano, except those penetrated in wells (D-13-13) 3cdb, (D-15-14) 3dad, and (D-15-14) 2dbc (pl. 2, sections $A-A^{\prime}$ and $\left.F-F^{\prime}\right)$, which contain rock detritus that is similar in appearance to the Catalina Gneiss. Most of the Pantano penetrated by wells has no less than 30 percent sand and gravel (detritus greater than $0.061 \mathrm{~mm}$ (millimeters) in diameter); the average content is about 50 percent sand and gravel; where 50 percent of the sample is sand and gravel, about 10 percent, or slightly more, is gravel (detritus greater than $2.0 \mathrm{~mm}$ ). Where the unit is coarsest (pl. 2, sections $H-H^{\prime}$ and $I-I^{\prime}$ ), about 75 percent is sand and gravel, and about 50 percent is gravel. Exposures of the Pantano Formation and equivalent sedimentary sequences are similarly coarse grained; but at the type locality, the lower 3,700 feet contains abundant mudstone, and the upper part contains gypsiferous mudstone. The gypsiferous mudstone is Finnell's unit 5, which is possibly equiva- 
lent to the lower part of the Tinaja beds. Pashley (1966) and previous workers noted a fine-grained facies of the possibly equivalent Rillito I beds in the foothills of the Santa Catalina and Tanque Verde Mountains. The Pantano contains mudflow-landslide breccia and very large individual block landslides (Cooper, $1960 \mathrm{a})$. Some of the outcrops in the foothills of the Rincon and Santa Catalina Mountains that generally are mapped as Precambrian granite and undifferentiated Mesozoic rocks may be large landslide masses emplaced during the deposition of the Pantano.

The center of deposition and, thus, the repository for the bulk of the fine-grained less permeable sediment may be the Davidson Canyon area, assuming that the correlations suggested on plates 1 and 2 are correct. The mass of lava and the dearth of sediment of equivalent age in the Tucson Mountains area seem to preclude a regional westward drainage trend despite the west-dipping crossbeds noted in the Rillito I beds (Pashley, 1966, p. 67-69, 72; Cooley and Davidson, 1963, p. 23).

The porosity of the sandstone and gravel in the Pantano Formation and correlative units, as determined by borehole formationdensity logs, ranges from 20 to 27 percent, and the permeability, derived from aquifer tests, is estimated to range from about 5 to about 100 gpd per sq ft (gallons per day per square foot). The porosity determined from individual drill cores ranges from about 25 to 40 percent; however, because of uncertainty as to the extent of compaction or expansion of the cores, the porosity data derived from borehole logging probably are more accurate. In most places the permeability is great enough that a well tapping 500 to 1,000 feet of the Pantano will yield at least $20 \mathrm{gpm}$ (gallons per minute) per foot of drawdown, and some wells have specific capacities of as much as $40 \mathrm{gpm}$ per foot of drawdown. The yields of wells having diameters greater than 12 inches range from a few hundred to almost 5,000 gpm. No data are available to define accurately the storage coefficient of this unit, but in most of the basin the long-term specific yield probably is at least 10 percent of the saturated volume. The storage coefficient computed from aquifer tests of the Pantano is in the leaky artesian range of 0.001 to 0.01 ( 0.1 to 1 percent), but under conditions of long-term drainage, a greater specific yield than that calculated from the relatively short period of an aquifer test is predictable.

Ground water in the Pantano generally is of good chemical quality; however, the quality is dependent on the lithology of the facies (Laney, 1972). The water contains slightly more dissolved solids and fluoride and is harder than the water in the younger 
units. In most places the dissolved-solids content is greater than $300 \mathrm{mg} / \mathrm{l}$ (milligrams per liter). The dissolved-solids content is more than $1,000 \mathrm{mg} / \mathrm{l}$ in water at shallow depth in the northeastern part of the basin and in water at greater depths in the eastern part of the basin. Water containing the smallest amount of dissolved solids is in gravel and sand, and that containing the largest amount is in siltstone and claystone. Water in the Pantano tends to contain more than $1.0 \mathrm{mg} / \mathrm{l}$ fluoride, and in some areas the fluoride concentration is 5 to $10 \mathrm{mg} / \mathrm{l}$. Most of the water is hard (120 to $180 \mathrm{mg} / \mathrm{l} \mathrm{CaCO}_{3}$ ), and some is very hard (more than 180 $\left.\mathrm{mg} / \mathrm{CaCO}_{3}\right)$. The dominant dissolved solids are calcium, sodium and bicarbonate, or calcium and sulfate to sodium and sulfate in areas where siltstone and claystone beds are abundant. The sodium sulfate type of water generally contains more than $50 \mathrm{mg} / \mathrm{l}$ chloride.

\section{TINAJA BEDS}

The Tinaja beds are a major part of the aquifer in the Tucson basin. They crop out only along the margins of the basin, where they are exposed because of erosion or nondeposition of overlying sedimentary units. The most continuous outcrops are in the foothills of the Santa Catalina and Rincon Mountains and in the Santa Rita Mountains and south of Tinaja Wash in the Sierrita Mountains. In the basin the beds are concealed by several hundred feet of overlying detritus but are partly or completely penetrated by many wells. The beds are 0 to more than 2,000 and perhaps as much as 5,000 feet thick; sandy gravel is the dominant lithology at the basin margins, but it grades to gypsiferous clayey silt and mudstone along the central axis of the basin.

The Tinaja beds unconformably overlie the Pantano Formation and are unconformably overlain by the Fort Lowell Formation. They include the Tinaja rocks mapped by J. R. Cooper (written commun., 1967), the Rillito II and Rillito III beds of Pashley (1966), and the gravels of Nogales mapped by Drewes $(1968 \mathrm{~b}$, p. 4, 15). Unit 5 of the Pantano Formation, as defined by Finnell (1970), may be equivalent in part to the lower Tinaja beds of this report. The Tinaja as used by J. R. Cooper crops out dominantly in the southern part of the Sierrita Mountains, where the upper part is a tuffaceous gravel deposit and the lower part consists of felsic flows and tuff and interbedded conglomerate and gravel. The Rillito beds crop out in the foothills of the Santa Catalina and Rincon Mountains, and the gravels of Nogales crop out in the southern part of the Santa Rita Mountains and near Nogales (Drewes, 1966). Finnell's unit 5 of the Pantano crops out along Cienega Creek in the eastern part of the Tucson basin. 
In the Sierrita Mountains the lower part of the Tinaja beds includes basaltic andesite and dacitic volcanic rocks that are of probable late Tertiary age-Miocene(?), or 26 to 12 m.y. old (Geological Society of London, 1964, p. 260-262). On Black Mountain (Percious, 1968) and in the Sentinel Peak-Tumamoc Hill area (Tolman, 1909), basaltic andesite flows are present; these flows are 26 m.y. to about 19 m.y. in age (Damon and Bikerman, 1964; Bikerman and Damon, 1966; Percious, 1968). The flows are considered to be correlative with the lower Tinaja beds.

The upper Tinaja beds rest unconformably on older rocks in many exposures near the basin perimeter. The geometry of occurrence of the upper beds in the basin implies an unconformable relation to the Miocene basaltic andesite flows on Black Mountain and in the Sentinel Peak-Tumamoc Hill area. Therefore, an unconformable relation is implied between the upper and lower Tinaja beds by correlation of the flows and the lower beds. The upper beds are probably Pliocene and perhaps late Miocene in age, but the suggestion of this age is permitted only by regional correlation with sediment of similar structural involvement and stratigraphic position (Cooley and Davidson, 1963, p. 27; Pashley, 1966, p. 90-91) that contain fauna of Pliocene age (Lance, 1960, p. 155-159).

The Tinaja beds are interpreted as a sedimentary detrital filling of a subsiding basin. The central part of the basin is a triangular downfaulted block bounded by the Santa Cruz fault, the fault parallel to Rillito and Tanque Verde Creeks, and a probable major fault that trends northeast through the basin. In much of the downfaulted block, the Tinaja beds are a clayey silt to mudstone in the lower part and a clayey gravel to clayey silt in the upper part, and outside of the downfaulted block the beds generally are a gravel or pebbly sand. The best evidence of the faulted nature of the block is in the southwestern part of the basin, where at least 2,000 feet of clayey silt and mudstone assigned to the Tinaja abuts hard, cemented gravel and conglomerate of the Pantano (pls. 1 and 2, Santa Cruz fault, particularly sections $C-C^{\prime}, H-H^{\prime}$, and $\left.I-I^{\prime}\right)$. A similar lithologic change, vertical offsets of rock units near well (D-13-14) 27acb (pls. 1 and 2, section $B-B^{\prime}$ ), and the linearity of Rillito and Tanque Verde Creeks indicate a probable fault contact between the lower Tinaja beds and the Pantano. Silty gravel to mudstone of the Tinaja beds is proximate to wellcemented gravel of the Pantano along the eastern side of the triangular block. The lateral lithologic change, which probably is due to a fault offset, is best illustrated on the eastern part of section $E-E^{\prime}$ (pl. 2). 
The Tinaja beds contain rock fragments derived from the nearest mountain masses; the beds were deposited in a basin that had about the same boundaries as the present basin, but the presence of silt and clayey silt in the Rillito Creek-Tanque Verde Creek area indicates that the relief of the Santa Catalina and Rincon Mountains was not nearly as great as it is today. The equivalent Rillito II and Rillito III beds, as described by Voelger (1953) and Pashley (1966), contain fragments of Catalina Gneiss of DuBois (1959) in increasing amounts toward the top of the beds. The graded upward increase in amount and size of gneiss fragments probably is due to the effect of a rising highland during deposition of the Rillito beds (Smith, 1910, p. 87; Pashley, 1966, p. 84-87). The center of deposition of the Tinaja beds was the center of the basin, and the lithology and the facies distribution indicate that the drainage was basinward. The fine-grained facies of the upper Tinaja occupies a smaller area in the west-central and southern parts of the basin (pls. 1 and 2, section $C-C^{\prime}$, well (D-14-14) 29cbc; section $F-F^{\prime}$, well (D-15-14) $17 \mathrm{dcb}$; section $H-H^{\prime}$, well (D-16-14) 25bbb) than does the fine-grained facies of the lower Tinaja. In the northern and eastern parts of the basin the beds contain abundant granitic fragments in a feldspathic to arkosic sand matrix; some of these beds may be mudflows or landslide breccias, but none have yet been positively identified. Volcanic and sedimentary rock fragments are present in varying amounts but do not constitute much more than 20 percent of the coarse, megascopically identifiable clasts. The percentage of volcanic and sedimentary rock fragments increases to the southeast. In the western part of the basin the Tinaja beds contain abundant fragments of volcanic rocks, which constitute 50 percent or more of the coarse materials at many well sites, and in the Sierrita Mountains, felsic flows and tuff beds are in the lower part and disseminated tuff and zeolite cement is abundant in the basal beds of the upper part. In the northern part of the basin, the volcanic-rock content decreases abruptly near the northwest-trending fault that extends from Tucson to Rillito; the decrease probably was caused by a south-facing scarp that diverted drainage along the fault. The volcanic-rock content also decreases toward Rillito. In the same area the Tinaja in the Canada del Oro area is mainly clasts of apparently locally derived granitic and metamorphic rocks that are spread out toward the center of the basin in a large fan.

The sand and gravel facies, toward the margins of the basin, are commonly gray to grayish brown in drill cuttings and less commonly medium brown to light reddish brown. The gravel facies contains about 50 to 90 percent material coarser than silt (more 
than $0.061 \mathrm{~mm}$ in diameter) and 20 to 50 percent material coarser than sand (more than $2.0 \mathrm{~mm}$ in diameter) ; the sand facies contains about 30 to 75 percent material coarser than silt and 5 to 20 percent material coarser than sand. The clayey silt and mudstone facies, toward the center of the basin, generally is reddish brown to medium brown and locally is light brown to brownish gray. This fine-grained facies generally contains only 5 to 25 percent material coarser than silt and commonly contains disseminated gypsum nodules in the uppermost beds and nodules, aggregates, and thin beds of fine- to coarse-crystalline anhydrite in the deeper beds. A 3-foot bed of silty tuff was cored in this facies in well (D-15-14) 25add at a depth of 1,585 feet (pl. 2, section $E-E^{\prime}$ ). A 3-inch bed containing hard, lustrous, and translucent green minerals occurred at the top of the tuff. X-ray analysis showed the presence of quartz, potassium and sodium feldspar, and mica (probably biotite). This bed might originally have been zeolite but due to burial is now altered to feldspar and quartz, analogous to the zeolite alteration reported by Hay $(1966$, p. 47, 93). Tuff fragments had been destroyed or were difficult to recognize in drill cuttings, but the mudstone facies probably contains numerous thin tuff beds. No zeolitic alteration or zeolitic minerals were specifically identified in the silt and fine-grained sand beds, but zeolite minerals are common associates of tuff in playa or lacustrine sediment similar to that in the Tucson basin.

The Tinaja beds are zero to a few hundred feet thick near the basin perimeter and are more than 2,000 feet thick in the center of the basin (pls. 1 and 2, sections $E-E^{\prime}$ and $F-F^{\prime}$, wells (D-16-14) 4baa, (D-15-14) 25add, and (D-15-14) 17dcb). The maximum thickness is unknown but might be as great as 5,000 feet in the central part of the basin. In most well cuttings the contact between the Pantano Formation and the Tinaja beds is difficult to select with certainty, and the contact between the upper and lower Tinaja beds cannot be precisely selected. The upper Tinaja beds probably are the thickest unit west of the Santa Cruz fault, but in the center of the basin the lower beds are much thicker than the upper beds. In the eastern part of the basin the lower beds are estimated to be about as thick, or slightly thicker than, the upper beds.

The lower Tinaja beds change from a pebbly sand or gravel to a clayey silt or mudstone in a very short distance eastward across the Santa Cruz fault in the western part of the basin, possibly because overland flow across the fault scarp was minor except in small areas. The change in the east is more gradual (pls. 1 and 2, sections $C-C^{\prime}, D-D^{\prime}$, and $F-F^{\prime}$ ), probably because the sediment 
was laid down in fans by moderate-sized streams that locally breached and eroded the fault scarps. The coarse deposits derived from the east appear to tongue out to the west (pls. 1 and 2, section $C-C^{\prime}$, wells (D-14-14) $16 \mathrm{ccc}$, (D-14-15) $20 \mathrm{bcc}$, and (D-14-15) 20bbc), but only more deep drilling will confirm this interpretation.

The upper Tinaja beds and the overlying Fort Lowell Formation are coarse grained in a zone that roughly parallels the faults that define the deep, southernmost structural basin; the coarsegrained material may be a beach deposit or a combined beach and sand-dune deposit similar to the beach ridges and dunes that surround the Willcox Playa (Cooper, 1960b). Wells near the Santa Cruz fault typically penetrate what may be called a scarp-associated clayey gravel facies (pl. 2, section $B-B^{\prime}$, well (D-13-13) 35adb; section $F-F^{\prime}$, well (D-15-14) 18bbb), and a similar facies is penetrated by other wells that are in proximity to inferred or probable faults (pl. 2, section $C-C^{\prime}$, well (D-14-14) 29aaa). Wells (D-16-15) 5bcc, (D-16-15) 9bbb (pl. 2, section $\left.E-E^{\prime}\right)$, and (D-15-15) 16cbb (pl. 2, section $D-D^{\prime}$ ) also may penetrate a scarpassociated clayey gravel facies. The fine-grained facies near the edges of the fault-bound depression locally includes discrete 40 - to 50-foot-thick lenses of sand (pl. 2, section $C-C^{\prime}$, well (D-14-14) 29cbc; section G-G', wells (D-16-14) $21 \mathrm{dbb}$ and (D-16-14) 25bbb; section $I-I^{\prime}$, well (D-17-14) 8cad) that also may have originated from erosion of the fault scarps and redeposition of the detritus. Alternately, the presence of some of the coarse detritus in the drill cuttings may be the result of contamination due to partial caving of the hole during drilling; without goodquality borehole geophysical logs, it is impossible to be certain of the actual existence of thin sand layers.

The porosity of the Tinaja beds, which was calculated from formation-density (gamma-gamma) logs of wells (D-13-14)31dba, (D-14-14) 16ccc, (D-15-15) 16cbb, and (D-16-15) 5bcc, ranges from 24 to 35 percent. The permeability of the sequence varies greatly-from about 10 to $400 \mathrm{gpd}$ per sq ft. Transmissivities range from 10,000 to 150,000 gpd per ft (gallons per day per foot). Well yields range from small to large, and specific capacities of wells range from about 1 to $40 \mathrm{gpm}$ per foot of drawdown.

The Tinaja beds are a major part of the currently producing aquifer in the Tucson basin, and although the fine-grained facies is not sufficiently permeable to yield water directly to wells, much of the water can be drained from the facies where it is underlain by or in juxtaposition to a more permeable unit. Water from the clayey silt and mudstone in the lower Tinaja beds contains fluoride 
concentrations objectionable for use as a public supply (Laney, 1972), and it contains larger amounts of dissolved solids than does water from the coarser facies. The water in the upper Tinaja beds generally contains less than $500 \mathrm{mg} / \mathrm{l}$ dissolved solids, is a calcium sodium bicarbonate to sodium bicarbonate type, and is hard to soft. Water in the lower Tinaja beds contains less than $500 \mathrm{mg} / \mathrm{l}$ dissolved solids where the unit is coarse grained but may contain more than $1,000 \mathrm{mg} / \mathrm{l}$ where the beds contain abundant silt or finer material. The water in the coarse-grained facies generally is a sodium bicarbonate type and is soft; where silt or clay is dominant, the main ions in solution are sodium or calcium and sulfate (Laney, 1972).

\section{FORT LOWELL FORMATION}

The Fort Lowell Formation, as named and defined in this report, is a locally derived sedimentary deposit that underlies most of the basin surface; the Fort Lowell is the most productive part of the aquifer in the Tucson basin. The formation was named for the abandoned Fort Lowell, which is near the intersection of Pantano Wash and Tanque Verde Creek. The Fort Lowell Formation was informally called basin fill by Pashley $(1966$, p. 63,111$)$ and probably is correlative with the basin fill of Davidson (1961, p. 151-153) in the Gila River valley and with the upper unit of the basin fill of Brown, Davidson, Kister, and Thomsen (1966, p. 16-18) in the upper San Pedro Valley. The Fort Lowell is known mainly from drill cuttings from wells in the basin and crops out extensively only in the foothills of the Santa Catalina and Rincon Mountains, where it unconformably overlies older rocks. The unconformable contact of the Fort Lowell and older rocks has been termed the "Rillito surface" by Pashley (1966). In the foothills as much as 400 feet (Smith, 1938, p. 69; Pashley, 1966 , p. 126-127, 137) of the formation has been stripped by postFort Lowell erosion, which has exposed the underlying Tinaja beds, Pantano Formation, and older rock units (pl. 1).

The type section of the Fort Lowell Formation has been described from drill cuttings and cores from well (D-13-14) 31 dba (pl. 2, section $B-B^{\prime}$ ), which was drilled by the U.S. Bureau of Reclamation for this investigation. The site for the type section was selected because the formation at the well is typical and because complete drill cuttings and cores are available. The samples and cores from the well are stored permanently by the U.S. Geological Survey and the Arizona Bureau of Mines in Tucson. In addition, several stratigraphic sections of the formation were measured by Pashley $(1966$, p. 116-121) in the Santa Catalina Mountain foothills. 


\section{Type Section of the Fort Lowell Formation}

$\left[\mathrm{NE}^{1 / 4} \mathrm{NW}^{1 / 4} \mathrm{SE} 1 / 4\right.$ sec. 31, T. 13 S., R. 14 E.; lat $32^{\circ} 15^{\prime} 22^{\prime \prime}$ N., long $110^{\circ} 56^{\prime} 52^{\prime \prime}$ W. Description of drill-hole cuttings and cores from well (D-13-14) $31 \mathrm{dba}$, by E. S. Davidson]

Late Pleistocene:

Thicknees (feet)

Surficial deposits overlying Cemetery terrace of Smith (1938):

9. Gravel, light-brown, sandy; caliche cement; clasts are mainly yellow granite, and banded gray and white granitic Catalina Gneiss of DuBois (1959); about 1 percent dark volcanic-rock pebbles, mainly andesite.

Total thickness of surficial deposits

Unconformity, erosional.

Early and middle Pleistocene:

Fort Lowell Formation:

8. Pebble gravel, reddish-brown, sandy; pebbles mainly banded gray and white granitic Catalina Gneiss and gray schist; trace of volcanic-rock pebbles.

7. Sand, light-brown, pebbly, medium- to coarse-grained; clasts mainly banded gray and white Catalina Gneiss; trace of red volcanic-rock clasts.

6. Sand, light-gray-brown, pebbly, coarse-grained; clasts of banded gray and white Catalina Gneiss.

5. Sand, medium-gray-brown, medium- to coarse-grained; clasts of banded gray and white Catalina Gneiss and gray schist; trace of reddish granitic gneiss clasts........

4. Sand, light-gray-brown, pebbly, coarse to very coarse grained; clasts of banded gray and white Catalina Gneiss; trace of red quartzite and reddish-brown volcanic-rock clasts. Core interval 200-210 ft: Sand, graybrown to light-brown, gritty, medium-grained, poorly sorted; a few pebbles as large as $3 / 4$ in. in diameter; clasts mainly quartz, feldspar, banded gray and white Catalina Gneiss, and gray schist; trace of dark-green volcanic-rock clasts and bright reddish-brown-stained granitic gneiss clasts..

3. Sand, medium-brownish-gray, silty, medium- to coarsegrained; clasts mainly banded gray and white Catalina Gneiss and gray to dark-gray schist; trace of lightcolored felsitic volcanic-rock clasts.

2. Sand, light-reddish-brown, silty, medium- to coarsegrained; fragments of banded gray and white Catalina Gneiss; trace of light-colored felsitic volcanic-rock fragments..

Total thickness of Fort Lowell Formation.................. $\overline{295}$

Disconformity (?).

Pliocene:

Tinaja beds :

1. Sand, light-gray-brown, gritty to pebbly and silty, mediumto coarse-grained; clasts mainly of banded gray and white Catalina Gneiss; about 1 percent dark volcanic- 
Type Section of the Fort Lowell Formation-Continued

Pliocene-Continued

Tinaja beds-Continued

Thickness

(feet)

rock clasts that increase toward base of unit. Core interval 400-407 ft: Sand, medium-brown, fine- to medium-grained; local 1-in. layers of hard, carbonate-cemented sandstone; clasts of banded gray and white Catalina Gneiss; as much as 5 percent volcanic-rock and dark phyllite clasts..

Base of described section. Drill penetrated sandstone (108 ft) underlain by mudstone (117 ft) of the Tinaja beds to a total depth of $700 \mathrm{ft}$.

The Fort Lowell Formation probably is correlative with beds of similar structural and lithologic habit that crop out in the San Pedro Valley 40 miles southeast of Tucson and in the Safford basin 80 miles northeast of Tucson. The correlative beds in these areas contain a Blancan fossil fauna (Knechtel, 1938) ; in the 111 Ranch area, in the Safford basin, the upper 70 feet of the correlative beds contains a fauna of Irvingtonian age (Lance, 1958; Wood, 1960). The Blancan fauna at other localities is dated in the range of 1.4 to $4.0 \mathrm{~m} . \mathrm{y}$. before the present by the potassium-argon method, and a faunal collection of Irvingtonian age is dated at $1.36 \mathrm{~m} . \mathrm{y}$. (Evernden and others, 1964, p. 164). The base of the Pleistocene is 2 to $3 \mathrm{~m} . \mathrm{y}$. before the present (Holmes, 1964). The following epoch, the Holocene, applies mainly to the flood-plain and channel deposits associated with the present-day streams in southeastern Arizona. The flood-plain and channel deposits are probably less than 11,000 years old, if the terrace deposits elsewhere in southeastern Arizona dated at 11,000 years (Lance, 1960, p. 157) are about the same age as the Jaynes terrace surficial deposit along the Santa Cruz River and tributaries in the Tucson basin. The Jaynes terrace deposit is older than the flood-plain and channel deposits along the present-day streams. The Fort Lowell, by correlation, probably is early and middle Pleistocene in age. Some of the beds near the base of the formation may be Pliocene in age, but, to date, the known fossils of Pliocene age (Lance, 1960) are in rock units that I correlate with the Tinaja beds.

The Fort Lowell Formation is 300 to 400 feet thick in most of the basin and thins toward the mountains, toward the heads of Canada del Oro and Pantano Wash, and toward Rillito (pls. 1 and 2). In surface outcrops the formation rests unconformably on the Tinaja beds and their correlatives and on older rocks; however, the unconformable relation is difficult, if not impossible, to detect in drill cuttings or core samples from most wells. In most 
of the basin both the Fort Lowell and the Tinaja beds are flat lying, and the contrast seen near the basin perimeter between the gently inclined to flat-lying Fort Lowell and the slightly to steeply inclined Tinaja beds is absent. Therefore, in the subsurface the lower contact is chosen on the basis of (1) a color-hue change from dark-reddish-brown Fort Lowell to less-dark-brown or gray Tinaja beds, (2) a marked increase in cementation from the Fort Lowell to the Tinaja beds, as noted in drillers' and geophysical $\operatorname{logs}$, and (3) in the northeastern half of the basin a change from a limited variety of rock detritus in the Fort Lowell to a more varied rock-fragment content in the Tinaja beds. The Fort Lowell-Tinaja contact is indefinite in many places, probably because of reworking of the Tinaja beds and redeposition of the sediment in Fort Lowell time. In some outcrops in southern Arizona, sedimentary units probably correlative with the Fort Lowell have been deposited against fault scarps along faults that offset units probably correlative with the Tinaja beds (Montgomery, 1963). The Fort Lowell-Tinaja beds contact was subjectively chosen in many wells shown on the sections (pl. 2) on the basis of lithology, color, and correlation of vertical variations in grain size with the grainsize pattern in nearby wells where the contact is more definite. The choice of contact determines the thickness of both units and helps identify the faults that offset the Tinaja beds; however, the contact placement has little or no effect on the hydraulic continuity of the aquifer because the permeability variations and partial barrier effects are not controlled by the placement of the stratigraphic contact.

Although the Fort Lowell is locally faulted and differentially tilted, the fault displacements appear to be minor, and the tilt is slight; therefore, the Fort Lowell is shown in the sections (pl. 2) as a depression-filling deposit along faults that offset the Tinaja beds. The upper contact of the Fort Lowell is an erosional surface in most of the basin, where the Fort Lowell is partly eroded and is overlain by lighter colored surficial alluvium associated with the present-day streams. In some places, notably in the fan near the mouth of Sawmill Canyon in the Santa Rita Mountains and along the eastern and western marginal slopes of the basin, the Fort Lowell does not appear to have been eroded, and a red clayey soil underlain by a caliche-cemented zone has developed in the uppermost few feet of the unit. Although the red soil is exposed locally at the land surface, it usually is concealed by a few inches to a few feet of overlying younger alluvial detritus. In the Tucson urban area, the highest topographic surface (University terrace) is the top of the Fort Lowell, and a very thick and dense caliche 
layer underlies the surface; most of the overlying clayey soil that is prevalent in the marginal parts of the basin has been eroded.

The Fort Lowell Formation grades from a silty gravel near the margin of the basin to a silty sand and clayey silt in the central part of the basin (pls. 1 and 2, sections $C-C^{\prime}$ and $F-F^{\prime}$ ). The grain-size distribution is similar to that in the upper part of the Tinaja beds, but the Fort Lowell consistently contains more coarse material than does the Tinaja. In most of the basin the Fort Lowell is 50 to 90 percent material coarser than silt (more than $0.061 \mathrm{~mm}$ in diameter) and 25 to 60 percent material coarser than sand (more than $2.0 \mathrm{~mm}$ in diameter). The center of deposition and the site of the thickest section of clayey silt are near wells (D-15-14) $17 \mathrm{dcb}$ and (D-15-14) 10bbb (pls. 1 and 2, section $F-F^{\prime}$ ). In the center of deposition, where the formation is clay and silt, about 25 percent is coarser than silt, and less than 5 percent is coarser than sand.

The sediment of the Fort Lowell is loosely packed to weakly cemented and ranges in color from dark to light reddish brown. The detrital material is derived locally, and in most of the basin the most common lithology is granitic fragments in a quartz-feldspar sand and montmorillonitic clay matrix (Laney, 1972). Clasts of sedimentary and volcanic rocks are abundant in the southwestern half of the basin (Laney, 1972), and volcanic fragments are common along the Sierrita and Tucson Mountains. The relative percentage of volcanic-rock fragments decreases gradually toward Rillito and decreases abruptly along the north-trending fault that extends from Tucson to Rillito.

The distribution of the facies and rock fragments indicates that the formation accumulated in a closed basin; in most of the area the formation was deposited in fans by streams that spread out from the canyons in the surrounding mountains. I infer that the coarse material in wells (D-15-15) 17acd, (D-15-15) 16cbb (pl. 2, section $\left.D-D^{\prime}\right)$, (D-15-14)25add (pl. 2, section $\left.E-E^{\prime}\right)$, (D-16-14) 21 ccb, (D-16-14) 21 dbb, and (D-16-14) 25bbb (pl. 2, section $G-G^{\prime}$ ) is a beach gravel or combination beach gravel-sand dune-delta deposit that surrounded a playa or lake. The Fort Lowell probably contains masses of landslide detritus in the northern and eastern parts of the basin. A mudflow was identified from samples dredged from water well (D-14-14) 6adc. The mudflow detritus consists of an unsorted mixture of fragments ranging from pebble gravel to clay in size. The fragments are entirely granodioritic Catalina Gneiss; the large fragments are sharply angular and firmly cemented by a fine matrix and interstitial calcium carbonate. The mudflow probably originated in the Santa 
Catalina Mountains. The other mountains that bound the north and east sides of the basin are similar in topography and geology to the Santa Catalinas and probably also contributed landslide detritus to the Fort Lowell Formation.

The Fort Lowell Formation is the thickest highly permeable unit in the Tucson basin aquifer and currently supplies most of the water used in the basin. The porosity was computed from geophysical logs of four wells in which 50 percent or more of the material is sand or gravel. The porosity ranges from 26 to 34 percent, and the average porosity is about 30 percent. Transmissivity values indicate that, the permeability of the Fort Lowell ranges from about 150 to at least $700 \mathrm{gpd}$ per sq ft. Well yields are commonly in the range of 500 to $1,500 \mathrm{gpm}$. The specific capacities of wells that yield water primarily from the Fort Lowell Formation range from 10 to $100 \mathrm{gpm}$ per foot of drawdown. Nearly all the water contains less than $500 \mathrm{mg} / \mathrm{l}$ total dissolved solids; the water is a calcium sodium bicarbonate type that is moderately hard to hard (pl.6). In general, the water is well suited for public supply (Laney, 1972).

\section{SURFICIAL DEPOSITS}

The surficial deposits are mainly gravel and gravelly sand and locally sand to sandy silt of fluvial origin and include alluvial-fan, sheetflow, and stream-channel deposits. The surficial deposits overlie and partially conceal all older sedimentary units and range from a thin veneer to a cover tens of feet thick. The deposits underlie three main topographic benches or levels (Smith, 1910, p. 85; Smith, 1938, p. 58-59) and the present-day stream flood plains and channels (Smith, 1910, p. 85, 190). Smith (1938, pl. V) called the uppermost topographic bench the University terrace, the intermediate bench the Cemetery terrace, the lowest bench the Jaynes terrace, and the surfaces of the flood plains and channels the bottom land. The bench deposits are topographically the highest and are drained of ground water; the deposits along the streams, however, are large-yielding aquifers that allow large amounts of streamflow to infiltrate to the underlying sedimentary rocks.

The surficial deposits are confined mainly to the basin; the only mappable surficial deposits that extend along the canyons into the mountains are the stream alluvium and the Jaynes terrace deposits. The Jaynes terrace deposits bound the present-day flood plains (pl. 1) ; however, in many places they have been completely eroded, and in a few places they are buried by younger stream alluvium. The Cemetery terrace deposits have been differentiated only along the foothills of the Santa Catalina Mountains (pl. 1), where they overlie rocks older than the Fort Lowell Formation, but in the rest 
of the mapped area the Cemetery and University terrace deposits are undifferentiated. The distribution of these surficial deposits was defined originally by Smith $(1938, \mathrm{pl} . \mathrm{V})$ and was revised recently by Pashley $(1966$, p. 131). In places near the basin margins and less commonly in the central part of the basin, the University terrace is underlain by weathered partly eroded caliche-cemented beds of the upper Fort Lowell Formation (Smith, 1938, fig. 12; Pashley, 1966, p. 133). In other places, where erosion was less severe, the University terrace is underlain by Holocene detritus, some of which is being deposited at the present time.

In the central and northeastern parts of the basin and generally along the major stream courses, the older terraces are topographically higher than the younger terraces, and the older terrace deposits are incised and are in erosional contact with the younger terrace deposits. Where erosion was severe, the incisement extends through the higher terrace deposits into the underlying Fort Lowell Formation or older units (Pashley, 1966, fig. 40). Conversely, burial of the older terrace deposits by younger detritus occurs where stream cutting has not been severe, such as on the slopes of the basin along the Santa Rita Mountains from the south edge of the mapped area to Pantano Wash, along the northeastern front of the Sierrita Mountains, and in two segments along the Santa Cruz River. In these areas the easily seen erosional bench steps merge into the smooth and flattened surface of a normal depositional stratigraphic sequence, in which successively younger deposits overlie older deposits. In the reach of the Santa Cruz River upstream from the Black Mountain-Sahuarita Butte area and upstream from Rillito, the older deposits are preserved and buried by deposits of successively younger alluvial detritus. A clay bed penetrated at shallow depth by wells along the Santa Cruz River near Black Mountain may be a soil at the top of the Fort Lowell Formation and thus may be equivalent to the soil on the University terrace, which is exposed at higher altitudes in the foothills of the Santa Catalina, Santa Rita, and Sierrita Mountains.

The oldest surficia! deposits are associated with the University terrace, and the youngest deposits are in the channels of the present-day streams. In some places the University terrace is the uppermost weathered surface of the Fort Lowell Formation; in other places the University terrace is underlain by present-day fluvial sand and gravel. Fort Lowell deposition ended in middle Pleistocene time; work in other areas indicates that the deposition stopped in Irvingtonian time (Lance, 1958; Wood, 1960), or about $1.3 \mathrm{~m} . y$. ago (Evernden and others, 1964, p. 164). The University terrace deposits are necessarily younger. The Jaynes terrace 
deposit may be equivalent in age to other upper Pleistocene deposits in southeastern Arizona, which contain carbon that is less than 11,000 years in age (Lance, 1960, p. 157).

The surficial deposits associated with and underlying the terraces range from 5 feet to probably no more than 100 feet in thickness, but the average thickness is less than 30 feet. Along the streams, the deposits are 40 to about 100 feet thick (pl. 2) and average about 50 feet thick. The deposits are thickest where post-Fort Lowell erosion was less severe, such as upstream from Sahuarita Butte and Rillito; where deposition was continuous, the contact between the surficial deposits and the Fort Lowell Formation is not sharp and may be gradational.

The terrace and stream alluvium is coarse gravel, silty gravel, and gravelly sand to sandy silt. The Pantano Wash and Santa Cruz River alluvium contains more silt than the alluvium of Canada del Oro, Rillito Creek, and other tributaries in the foothill areas. The older deposits are more firmly packed and cemented than the younger deposits in the stream channels; the deposits underlying the University terrace have the thickest caliche (Smith, 1938, p. 63). The deposits along the streams are loosely packed and generally are not cemented. The rock fragments in the surficial deposits reflect the composition of the nearby mountains and foothills. In the northeastern part of the basin the rock types in the surficial deposits are more varied than those in the underlying sedimentary units, but this distinction is less common in the rest of the basin. Granite and granitic gneiss fragments are the most common rock types, except in the western part of the basin, where several types of volcanic rocks are more common. The granitic gneiss fragments typically are stained by yellowbrown iron oxide, a property that is helpful in differentiating surficial deposits from underlying sedimentary units in well cuttings (Pashley, 1966, p. 143). Fragments of various types of sedimentary rock and schist are minor constituents in the surficial deposits throughout the basin but are most common in the southeastern part.

The surficial deposits are detritus that was principally in transit; the significance of these deposits was noted by Bryan and Smith (in Smith, 1938, p. 59, 62, 74-78), who interpreted the gravels on the benches as deposits on erosional surfaces created by successive lowering of the controlling streams. The deposits were transported and deposited by a north- and northwest-flowing stream system, which represents a drastic change in sedimentation from the basin-confined surface drainage that resulted in deposition of the Tinaja beds and the Fort Lowell Formation. 
The surficial deposits are not significant hydrologically in most of the basin because nearly everywhere the water table is below these deposits and because most rainfall evaporates or is used locally by plants and is transpired. Although the deposits along the stream courses are extremely permeable, they are not saturated along much of the Santa Cruz River and Pantano Wash, mainly owing to pumping and the concurrent lowering of the water table. However, the alluvium is saturated along some reaches of Rillito Creek and along many of the small tributary streams. The stream deposits are very porous, and their present hydrologic function is to receive and store temporarily the natural recharge from floodflow. Some of the recharge replenishes the moisture demand of the stream alluvium and is soon transpired by plants along the stream, but most of the recharge is transmitted to the underlying aquifer.

STRUCTURE OF SEDIMENTARY UNITS IN THE BASIN

The structural interpretation presented in this report is dependent on the accurate correlation of the sedimentary units in the basin and on the inference, based on drill-core samples, that most of the sedimentary beds in the central part of the basin are flat lying to slightly tilted. An offset of units by a fault has been inferred where a smooth geometric surface that connects identifiable geologic contacts is displaced to another geometric surface at a different altitude. Where such a fault has been inferred in this report, the change can be documented by several wells within about half a mile of the fault; the surface of the geologic contact must have been identifiable in several wells, and the offset must have been interpretable as a linear feature in plan view. Although the surface formed by the contacts may have a different slope on either side of the fault, a vertical offset along the fault is the most obvious effect of the displacement. Faults also have been inferred along abrupt lateral changes from a sediment containing at least 75 percent sand and gravel to a sediment containing no more than 25 percent sand and gravel. In these places a fault is suggested where the change occurs laterally within about 1 mile and where the change is documented in a few hundred feet or more of the vertical section.

In most places, particularly where faults are shown as approximately located or inferred, a marked change in lithology, primarily in rock-fragment content and cementation, also occurs across the fault. In places where the faults are shown as probable, the lithologic change was interpreted as being due to a fault, but it could also be due to a lateral facies change in the sediment. The 
hydrologic effect of an incorrect interpretation would be slight because the abrupt lateral changes, whether due to a fault or a facies change, will alter the movement of ground water in the same manner. In many places the inferred and approximately located faults are loci of various anomalies in ground-water characteristics, such as a water temperature higher than normal in relation to the well depth, an anomalously high or low artesian water level, or an anomalous chemical quality. As a general rule, the fine sediment was assumed to be on the downdropped side of the fault block because the interpretation parallels interpretation of gravity data (pl. 5). In a few places the interpretation is verified by displacements of clearly identifiable geologic units.

The oldest fault trends northwest from Tucson to Rillito. This fault may extend across the southern edge of the Rincon Mountains and may have regional significance (Poole and others, 1967, p. 893). The principal evidence for the existence of the fault is the proximity of northeast-dipping Tertiary volcanic rocks to an outcrop of northwest-dipping Precambrian or Cambrian quartzite at Rillito and an almost total lack of volcanic-rock detritus in the Tinaja beds and the Fort Lowell Formation north of the fault. If the fault exists, then the early Cenozoic, Cretaceous, and older rocks south of the fault are displaced downward 5,000 feet or more against the mass of the Rincon, Santa Catalina, and Tortolita Mountains. Early movement on the fault may have been cogenetic with northwest-trending tear faults in southern Arizona, which Drewes (1968a, p. 33) indicated formed contemporaneously with injection of quartz monzonite intrusives dated as 57-52 million years old (Paleocene), but the interpretation in this report is that the major movement along the Tucson-Rillito fault occurred in a later epoch. A more complete discussion and proof of this fault are beyond the scope of this report, but the presence of such an offset allows further logical explanation of the tectonics of the low-angle Catalina fault (Pashley, 1961, 1964, 1966; Fair and Jinks, 1961, p. 131-132), which may be contemporaneous or slightly younger in age. Briefly stated, rocks at the base of the Rincon Mountains, which generally are mapped as sedimentary rocks of Paleozoic and Mesozoic age, may be giant landslide blocks that slipped off the differentially higher granitic masses of the Santa Catalina and Rincon Mountains, as previously suggested by McColly (1961, p. 87-88). A middle Tertiary age (Oligocene (?)) for the major and first movement on the Tucson-Rillito fault is compatible with the interpretation of the facies and structure of the basin sediments, but a more complicated history of earlier movement and later recurrent movement is possible. 
A slightly younger fault system resulted from the downward displacement of the central part of the basin with respect to the surrounding mountains. The major displacement probably occurred during late Oligocene and early Miocene time, and the vertical offset ranges from about 600 to 2,000 feet. The principal faults of the system are the north-trending Santa Cruz fault (pl. 1), the northwest-trending fault in the center of the basin, the northeast-trending probable fault that cuts across the eastern part of the basin, and the fault parallel to Tanque Verde and Rillito Creeks. The relative displacement along the fault parallel to Tanque Verde and Rillito Creeks is questionable because of uncertainties in formational correlations between the basin and the Santa Catalina foothills.

The youngest major fault system is the series of mainly northeast-trending faults, some of which are inferred to cross the basin; this fault system offsets the pre-Quaternary rock units in the Tucson Mountains, the basin, and the Santa Catalina Mountain foothills. The displacement inferred along most faults of this system is less than 500 feet.

The most recent structural movement of the basin occurred in middle Pleistocene time at the close of deposition of the Fort Lowell Formation, when the drainage changed from a basin-confined system to the through-flowing system of the present. I believe that the change in drainage from internal to through-flowing was caused by the differential uplift of the basin with respect to the drainage of the Santa Cruz River downstream from Rillito. The magnitude of uplift, therefore, is comparable to the difference between the altitude of the top of the Fort Lowell Formation in the central playa area and the altitude of the top of the Fort Lowell Formation at Rillito. During deposition of the Fort Lowell, streams flowed from the Rillito area to the center of the basin; thus, the center of the basin was at a lower altitude than Rillito, probably by several hundred feet. The present altitude at Rillito is about 2,060 feet above mean sea level, and the altitude of the Fort Lowell Formation in the central playa area is about 2,600 feet; therefore, the uplift must have been more than 540 feet in 20 miles and may have been about 1,000 feet in order to reverse the probable gradient of 15-20 feet per mile during Fort Lowell deposition and to create the present gradient. A more accurate figure cannot be derived because of the uncertainty as to whether or not the upper part of the Fort Lowell Formation was eroded in the Rillito area. It appears that very little of the upper Fort Lowell was eroded because, from lowest to highest, the erosional terraces along the headwaters of the Rillito Creek and Canada del 
Oro drainages disappear under successively younger deposits toward Rillito. Deposition in the basin near and slightly upstream from Rillito apparently was continuous, and, therefore, very little Fort Lowell could have been eroded. The assumption is that the present land surface is a few tens of feet above the top of the Fort Lowell as originally deposited.

The faults were formed in response to periodic depression of the basin with respect to the mountains; the overall effect was a basin of dominantly internal drainage that existed for a long period of time. The relative and periodic depressions of the basin were deduced to have extended from Oligocene to middle Pleistocene time, a period of at least 25 million years. The deduction was made from correlations of the sedimentary units and interpretations of the structure. Davis (1967) constructed a residual gravity contour map of the basin that shows a generalized form of the deepening. In some places steep gravity gradients, which generally reflect fault displacement, are parallel to the major faults in the basin ( $\mathrm{pl} .5$ ). The greatest negative gravity values are along the central axis of the basin, and these values are presumed to confirm the axis as the loci of the greatest thickness of sedimentary deposits. In general, the deepest parts of the basin interpreted from gravity data correspond with the deepest parts inferred from the structural analysis; however, a major gravity low southeast of Sahuarita and a low along the valley of Canada del Oro have not been confirmed by drill-hole data. Both of these lows probably reflect a substantial thickness of sedimentary deposits, which may be partly bounded by major faults. The deep deposits in these gravity lows may not be sufficiently porous or permeable to be significant to the water resources of the basin, but confirmation of the existence of the thick deposits and their water-bearing potential depends on future exploration.

\section{HYDROLOGIC CHARACTERISTICS OF THE AQUIFER SYSTEM}

The water-yielding sedimentary units are hydraulically connected and form a single aquifer in the Tucson basin. The potentiometric surface, or level to which ground water will rise in a well, and the movement of water are affected by the aquifer facies that is tapped and by the faults that enhance or impede ground-water movement. The cementation and compaction of the units increase with age and depth of burial, and the dependent hydraulic factors - such as permeability, porosity, and specific yield - decrease accordingly. Water-level declines owing to ground-water withdrawal are dependent on the values of permeability and specific yield and on their distribution within the aquifer. 


\section{GROUND-WATER PUMPAGE AND WATER-LEVEL DECLINES}

The withdrawal and consumptive use of ground water have caused substantial water-level declines in the southwestern and northern parts of the basin. The annual pumpage increased from about 50,000 acre-feet in 1940 to about 177,000 acre-feet in 1965 (fig. $3 A$ ). Water-level declines in the areas of large withdrawals ranged from about $20^{\circ}$ to 70 feet (pl. $4 B$ ) ; however, the areas of greatest decline did not coincide everywhere with the areas of largest withdrawals, mainly because of areal variability in recharge.

The amount of ground water pumped in 1940-65 was about 3.3 million acre-feet. The resultant decline in water level was proportional to the volume of aquifer dewatered. Because water-leveldecline data were poor or nonexistent in many parts of the basin, particularly outside the margins of the areas of large withdrawal and in much of the basin where the decline was less than 25 feet, the entire volume of dewatered aquifer could not be accurately computed. A substantial error may have been introduced in calculating the volume of dewatered aquifer where the data points were widespread, because the computational technique integrated decline data from adjacent individual wells, the points of greatest decline; generally, no water-level data were known in the intervening areas, where the water-level decline theoretically was less. Therefore, the computed volume of dewatered aquifer is probably larger than the actual volume. A volume of about 7.8 million acre-feet of the aquifer is within the contoured area of water-level decline shown on plate $4 B$. Assuming the aquifer in this area was dewatered and had an average specific yield of 15 percent, the volume of water depleted from storage in 1940-65 was about 1.2 million acre-feet. The depletion of water in the entire aquifer may have been somewhat greater than 1.2 million acre-feet but probably did not exceed 2 million acre-feet.

The water-use trends (fig. $3 A$ ) - as documented by Schwalen and Shaw $(1957 ; 1961)$, Matlock and others (1965), and Anderson (1972) - indicate that the combined public supply and industrial usage will have surpassed irrigation usage within a few years. Pumping for public supply increased annually from less than 7,000 acre-feet in 1940 to slightly more than 54,000 acre-feet in 1965 ; in the same period the annual withdrawal for industrial usages increased from less than 1,000 to slightly more than 18,000 acre-feet, and the pumpage tripled to about 51,000 acre-feet in 1970. Irrigation pumpage ranged from about 42,000 to 141,000 acre-feet per year in 1940-65 but ranged from about 74,000 to 104,000 acre-feet per year in 1958-65 (fig. 3A). 


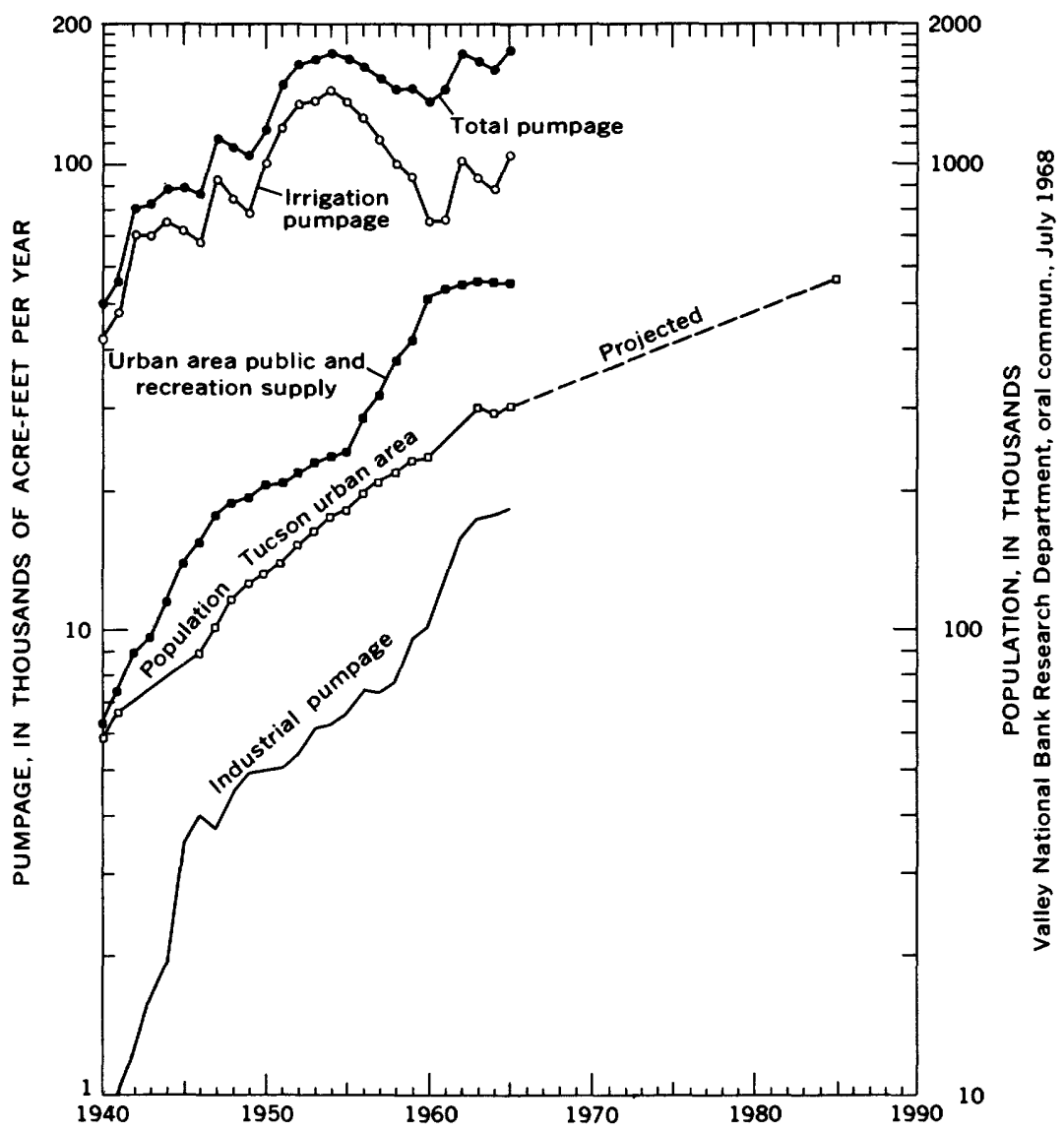

A. GROUND-WATER PUMPAGE AND URBAN AREA POPULATION

Figure 3. - Population, pumpage, and May through October precipitation, 1940-65.

An accurate knowledge of pumpage volume and distribution in addition to an accurate estimate of hydrologic conditions in the aquifer are necessary for a correct analysis of a water-level decline in response to pumpage. Therefore, some of the possible errors in pumpage estimates are herein described, as these errors might alter the analog analysis completed during this investigation.

The ratio between the estimated water use for public supply and the population was not uniform in 1940-65 in either the incorporated city of Tucson or in the larger urban area (fig. $3 B$ ), probably owing to inaccuracies in estimates of both pumpage and population. An alternate interpretation, that the substantial vari- 

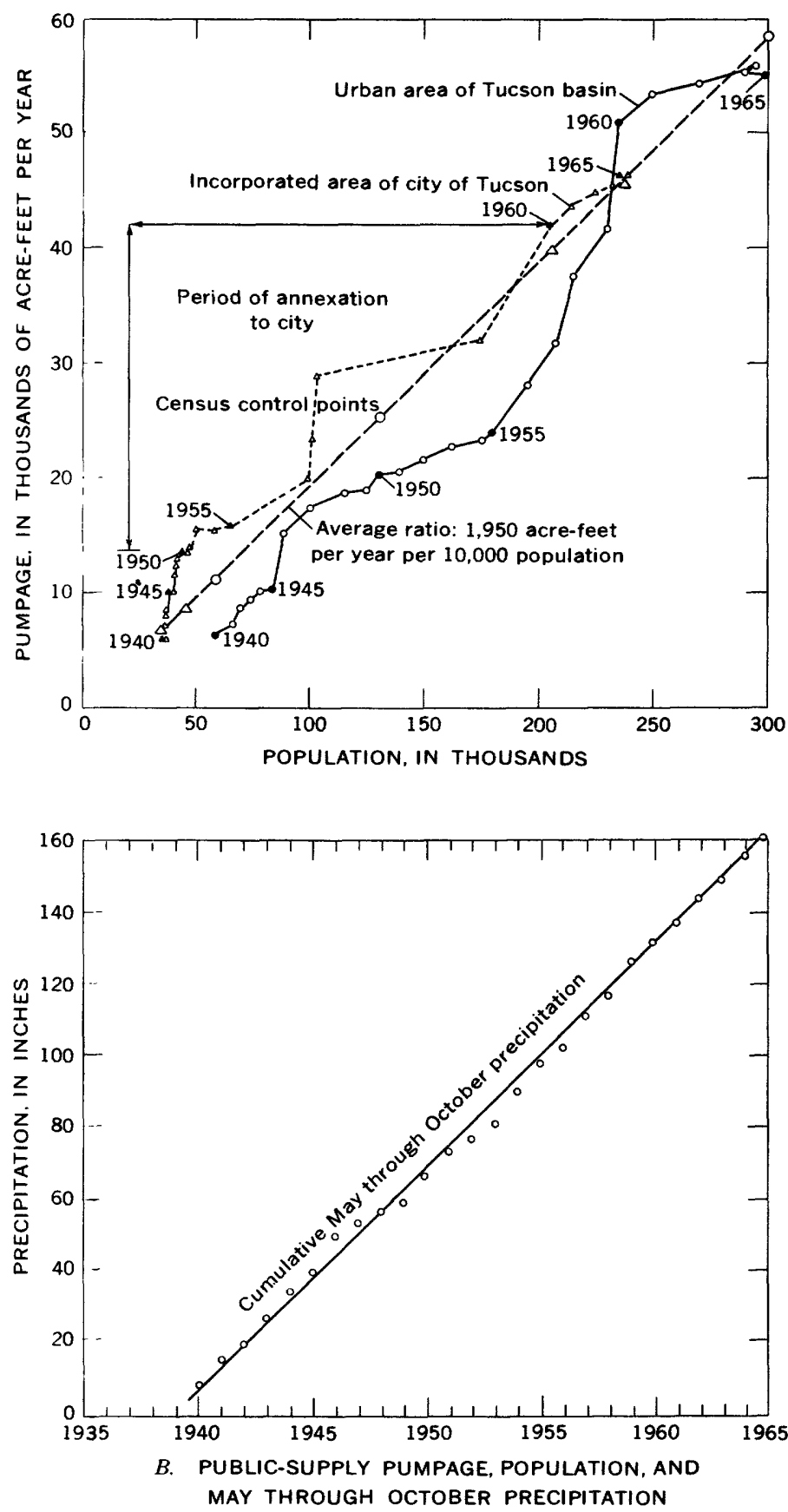

ation in water use in relation to population was due to variation in rainfall because less water was used for lawns, parks, and other 
outdoor greens during periods of high rainfall, is not true. Variation in summer precipitation, shown as a cumulative graph (fig. $3 B$ ), was not great enough to cause the much larger variation in water use per unit of population.

The most accurate concurrent pumpage and population data available are for the city of Tucson in 1965, when most of the pumpage was metered and a special census was taken. The pumpage was about 46,000 acre-feet, and the average population was about 235,000 - a ratio of 1,957 acre-feet of pumpage per year per 10,000 population, or $175 \mathrm{gpd}$ per person. A ratio of 1,950 acrefeet of pumpage per year per 10,000 population (fig. $3 B$ ) is a reasonable approximation for the incorporated city of Tucson for 1940-65. The pumpage probably was overestimated for 1945-55 and 1957-58 because of uncertainties created by area annexation and the lack of metered well production.

In the Tucson urban area, if the ratio of water usage to unit population is approximately the same as that within the city, and if the population estimates are reasonably accurate, then the pumpage estimate seems too low, particularly for 1950-59. The low urban-area pumpage estimate may be due either to an underestimation of pumpage by as much as 10,000 acre-feet per year or to a much lower rate of water use outside of the incorporated city than within. Because the pumpage estimates in the incorporated city appear to be reasonable, the pumpage in the urban area surrounding the incorporated city probably was underestimated. In 1950-59 the area outside the incorporated city that contained the greatest population was within or near the area of greatest water-level decline, and only nominal pumpage was estimated in this area (pl. $4 B$ ) ; therefore, the pumpage may have been underestimated. However, a check on population in that area indicated that the amounts of pumpage used in the analog model were reasonably accurate (Walter Stein, city of Tucson Water Department, oral commun., 1970). The cause of the apparently inconsistent lower water use per unit population in the Tucson urban area is not known.

Using the estimated pumpage for the urban area for 1940-64, the electrical-analog model required a specific yield of 4 to 5 percent in the area of greatest water-level decline in order to simulate the measured water-level decline. If the pumpage estimate for the urban area were increased to correspond to the value calculated from the use-population ratio of the incorporated city, the waterlevel decline would be simulated by using a specific yield closely equivalent to the more reasonable 15 percent used for most of the Tucson basin. 
The amounts of water-level decline and pumpage (pl. $4 B$ ) in 1940-65 are shown by lines of equal water-level decline and of equal pumpage. The lines showing water-level decline were drawn on plate $4 B$ using measurements made in individual wells throughout the basin. The pumpage volume of 3.3 million acre-feet for the entire 25-year period was distributed in quarter-square-mile areas based on well-density, pumpage, and crop-acreage records (Anderson, 1972). For convenience, the points that represent the center of pumping in a quarter-square-mile area are the section and quarter corners and the center of the section. Because many grid points were not assigned any pumpage values, the pumpage values were redistributed for mapping by averaging the value at each point with the values at the eight surrounding points; the resulting value per quarter square mile was divided by 160 acres to yield a value of acre-feet of pumpage per acre (pl. $4 B$ ), a value which is equivalent to feet of water. Because of the method of averaging, some pumpage values were outside the aquifer boundary, but their effect was negligible. A direct mathematical comparison of pumpage and water-level decline was not possible, owing to the difficulty inherent in empirically distributing the pumpage in relation to the water-level decline. However, a comparison, in feet, of water withdrawn and water-level decline shows the relative response from place to place.

The greatest water use was along the Santa Cruz River, where the withdrawals generally were from 20 to 75 acre-feet of water per acre for the 25-year period. Most of the water was used for irrigation, although some of the water pumped near and a few miles south of Tucson was used for public supply. Another area of large water use was in the urban area, where the withdrawal ranged from about 5 to 20 acre-feet per acre; nearly all the ground water was used for public supply.

The centers of greatest water-level decline were along a 12-mile reach of the Santa Cruz River near Sahuarita and from the eastern part of the urban area to a few miles southeast of the confluence of Rillito Creek and the Santa Cruz River. Water levels declined 50 to 70 feet in these two areas, but the withdrawal in the cone of depression underlying the urban area was much less than that in the cone underlying the Sahuarita area.

The areas of greatest withdrawal along the Santa Cruz River showed 1.2 to 1.4 feet of water-level decline in response to 1 acrefoot per acre of pumpage. In some places along the river, where the pumpage volume was smaller, the decline was 2 to 4 feet in response to 1 acre-foot per acre of pumpage. Along the Santa Cruz River in the Cortaro area, where the aquifer receives recharge 
from all the major tributaries and from the Tucson sewage system effluent, the decline in the central part of the cone of depression was about half a foot for each acre-foot per acre of pumpage.

The relatively slight response of water-level decline to pumpage along the Santa Cruz River was due to the frequent significant amounts of recharge to the ground-water reservoir through infiltration of streamflow. In contrast, pumping from wells in T. $14 \mathrm{~S}$., Rs. 14 and $15 \mathrm{E}$., in the Tucson urban area, caused about 3 to 4 feet of decline in response to 1 acre-foot per acre of pumpage; the water-level decline per unit of pumpage was greater because of a lack of significant nearby recharge and a smaller specific yield of the aquifer there than along the river.

The ratio of water-level decline to pumpage is nonlinear. This ratio is dependent on the proximity to sources of recharge and to partial or nearly impermeable hydraulic boundaries, on the relative intensity of pumpage, and on the transmissivity and specific yield of the aquifer. The ratio of pumpage to decline may be substantially different in the future, but the ratio does give an approximation of the decline-pumpage ratio to be expected in undeveloped areas of the basin that are comparable in recharge and aquifer characteristics to the present developed areas.

RELATION BETWEEN HYDRAULIC HEAD, LITHOLOGY, AND FAULTS

Ground water in the Tucson basin aquifer is unconfined or partly confined at the present depths of development. Data from a few deep test wells indicate that the hydraulic head generally decreases with depth where the aquifer is mainly gravel or sand and increases with depth where the aquifer includes thick sequences of silt and clayey silt. The change in hydraulic head with depth does not seem to be a result of or closely related to ground-water withdrawal.

The hydraulic head in wells (D-15-15)16cbb (pl. 2, section $D-D^{\prime}$ ) and (D-16-15) 10cce (pl. 2, section $E-E^{\prime}$ ) decreases about 35 to 60 feet per 1,000 feet of depth (table 1). Wells in secs. 2 and 3 , T. 15 S., R. 14 E., show decreases in hydraulic head in the same order of magnitude with depth; the water level in well (D-15-14) 18bbb, which is very near a crossfault (pls. 1 and 2, section $F-F^{\prime}$ ), dropped about 75 feet when the well was deepened from 500 to 830 feet. The aquifer in these areas is mainly gravel and sand.

An increase in head with depth occurs in the clayey silt to mudstone facies of the Tinaja beds or in places where a thick sequence of mudstone divides the aquifer. These conditions are present mainly in the downfaulted central part of the basin. The 
TABLE 1. - Relation between the depth below land surface and the hydraulic head in wells

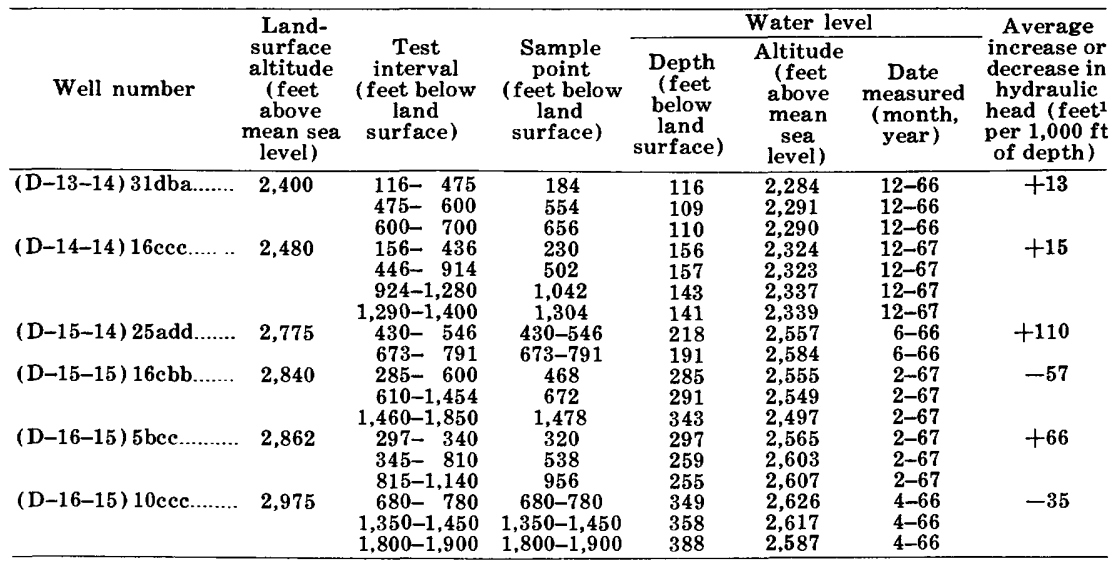

${ }^{1}$ Rounded to nearest foot; average increase or decrease from shallowest to deepest sample point.

hydraulic head in wells (D-13-14)31dba, (D-14-14) 16cce, (D-15-14) 25add, and (D-16-15) 5bcc increases from about 15 to 110 feet per 1,000 feet of depth below the land surface (table 1). Well (D-16-15) 5bcc (pls. 1 and 2, section $E-E^{\prime}$ ) is the only well outside of the downfaulted central part of the basin that shows an increase in hydraulic head with depth. This well intersects finer grained material at depth than it does near the land surface and, as noted in the description of the Tinaja beds, may be in the downfaulted part of the basin. Well (D-15-15) 16cbb (pls. 1 and 2, section $D-D^{\prime}$ ), which is similarly located, shows a decrease in head with depth.

Water levels in wells on or near faults generally are anomalous and are both higher and lower than water levels in nearby wells. The fault that parallels Pantano Wash is probably responsible for the higher than normal water levels that occur in some wells near the mouth of Rincon Wash; two wells within 1,500 feet of each other in the NE1/4 sec. 1, T. 15 S., R. 15 E., are in the same topographic and physiographic position, but in the northernmost well the water level is anomalously 123 feet higher. The higher water level probably is artesian rise due to head transmission along the fault from an area having a higher hydraulic head.

The water-table altitude (pls. 1 and 2) represents the hydraulic head of the ground water in the upper part of the aquifer and is approximately the altitude of water in wells that tap the upper few hundred feet of the aquifer. The water table roughly parallels the land surface but has a gentler gradient than that of the land 
surface and slopes from the basin margins toward the outlet near Rillito. Ground-water movement, at least in the uppermost few hundred feet of the aquifer, is downgradient in a direction approximately perpendicular to the contours shown on plate 1 .

The slope of the water table increases abruptly in a broad arc across the central part of the basin from T. 14 S., R. 15 E., to the northwest part of T. 15 S., R. 14 E., and then flattens northwest of the arc generally because of hydraulic effects created by geologic structure. The gradient change in the southwestern part of T. 14 S., R. 15 E., probably is caused by the increased thickness of the more permeable, upper part of the aquifer northwest of the gradient increase. The more permeable material thickens on the northwest, or downgradient, side of a fault that displaces the Tinaja beds and that causes the northwestward thickening of the Fort Lowell Formation. A similar condition occurs in the northcentral part of T. 14 S., R. $15 \mathrm{E}$. The steepening of the water-table gradient noted by Smith (1910, fig. 49) in 1908 still exists in the northern part of T. 15 S., R. 14 E.; here, the change in altitude of the water table probably is due to a fault-induced facies change from clayey silt to the south to a more permeable, gravelly facies to the north. Wells in the northeastern part of this area show a decrease in head with depth, which also indicates a potential for the downward movement of ground water.

A gradient increase in the southeastern part of T. 16 S., R. 13 E., where steepening of the gradient and large water-level declines (pl. 4B) are more recent than those in the other areas, is due to ground-water withdrawal. The shape and extent of the waterlevel decline caused by the withdrawal may be affected now, and will be affected more as the decline increases, by the partial hydraulic boundary along the Santa Cruz fault; this partial boundary results from the much lower permeability of the clayey silt and mudstone east of the fault than the gravel west of the fault.

Although the water-table gradient is closely controlled by aquifer transmissivity in the steady flow condition, the relation in the Tucson basin of the gradient steepening and flattening to the transmissivity pattern derived from aquifer tests is by no means consistent. The most probable reason for this inconsistency is that the water-level gradient may be controlled by the transmissivity and the rate of water movement through the entire thickness of the aquifer, but the transmissivity of only the upper 500 to 700 feet of the aquifer can be evaluated by the aquifer tests.

TRANSMISSIVITY

The capacity of the aquifer to transmit water to wells or to sustain downgradient water movement is expressed as transmis- 
sivity. The transmissivity is the rate of flow in gallons per day, at the temperature of water in the aquifer, through a 1-foot-wide vertical section of the entire aquifer under a hydraulic gradient of 1 foot of head per foot of flow distance. The transmissivity is the product of the average coefficient of permeability and the thickness of the aquifer. In the Tucson basin the transmissivity was determined mainly from aquifer tests. In general, the greatest transmissivity and the largest yielding wells are along the Santa Cruz River and Rillito Creek.

The transmissivity values were computed by Anderson (1972), who used data from 240 short-term aquifer tests; the tests were supervised and conducted mainly by the staffs of the University of Arizona Agricultural Engineering Department and the Bureau of Reclamation. The general pattern of transmissivity (pl. 1) was established chiefly from the aquifer-test-derived values; supplementary values were computed from specific-capacity data and estimated from well logs.

The transmissivity values computed from aquifer tests range from about 1,000 to almost 500,000 gpd per ft (Anderson, 1972), but the transmissivity of most of the aquifer is less than 50,000 gpd per ft (pl. 1). Transmissivities of the next largest part of the aquifer range from 50,000 to $180,000 \mathrm{gpd}$ per $\mathrm{ft}$, and the transmissivities of small parts along the Santa Cruz River and Rillito Creek are from 180,000 to $300,000 \mathrm{gpd}$ per ft or more.

Specific capacities of wells commonly range from about 5 to 100 gpm per foot of drawdown. Most wells along the flood plain of the Santa Cruz River, where the transmissivity is greatest, have specific capacities of 20 to $50 \mathrm{gpm}$ per foot of drawdown, and most wells in the central part of the basin have specific capacities of 10 to $40 \mathrm{gpm}$ per foot of drawdown (Anderson, 1972).

RELATION OF TRANSMISSIVITY TO GROUND-WATER MOVEMENT

Transmissivity is critical in the determination of ground-water movement through the aquifer. The movement through a 1-footwide section of the aquifer was computed by multiplying the transmissivity by the prevailing hydraulic gradient, as measured by water-level contour lines. The formula for this calculation is expressed as

$$
Q=T I L,
$$

where

$Q=$ volume of flow, in gallons per day,

$T=$ flow, in gallons per day, per cross-sectional foot of aquifer,

$I=$ gradient, in feet per foot, and

$L=$ length of the cross section. 
A major part of the aquifer budget described in the section "Water Budget" was estimated by repeating such a flow computation around the inflow perimeter and across the underflow outlet of the aquifer. In this study the computations of inflow and outflow were made by mathematical calculations and by trial-and-error methods through the use of the electrical-analog model; the primary control was the transmissivity, which was both estimated and derived from aquifer tests. In addition, the distribution and values of transmissivity partially control the shape and extent of water-level declines caused by ground-water withdrawal. If the amount of withdrawal is equal throughout a given area, the water-level decline will extend over a wider area and be less deep in areas where the transmissivity values are greater than in areas where the transmissivity values are smaller.

The boundary of the aquifer defines the practical limit of ground-water movement and storage in the basin. The boundary was subjectively placed in several situations: where the saturated permeable aquifer is known to be very thin; near the basin margin, where the water-table gradient flattens basinward, which indicates that the aquifer thins toward the margin and thickens toward the basin; and basinward from outcropping rock units that are near the mountains and that are known to be very low in permeability.

\section{AREAL AND VERTICAL RELIABILITY OF THE TRANSMISSIVITY PATTERN}

The transmissivity pattern (pl. 1) is a reasonably accurate average for that part of the aquifer tapped by the many producing wells; this observation is based on results of the analog-model analysis and on lithologic information that has become available since construction of the model. The transmissivity pattern used in the model was not completely representative in areas where data were sparse, or along the stream courses, because there the model simulated the aquifer as a single average layer, whereas a more complicated analog would have been necessary to match the physical conditions of the aquifer. Transmissivity decreases as water levels decline, so transmissivities in some of the basin were higher under past conditions and will be lower in the future. Additionally, as water levels decline, some partial hydraulic boundary effects become more pronounced, but these effects were not simulated by the analog model because of constructional difficulties.

In the south-central part of the basin much of the lower part of the aquifer has low permeability, and the transmissivity pattern represents the overlying and adjacent more permeable parts of the aquifer; here, a water-level decline of about 30 feet from the 
1966 water level will dewater the more permeable part of the aquifer sufficiently to alter the transmissivity pattern. The areas of most serious inaccuracy are west of and above the thick clayey silt and mudstone of the Tinaja beds. These deposits have a low permeability and will not yield substantial amounts of water to wells or sustain ground-water movement with the facility indicated by the transmissivity pattern (pl. 1). If heavy pumping continues in the general area near Sahuarita (pl. $4 B$ ), the modelpredicted and actual future water levels will not match in the area along the Santa Cruz fault from about 5 miles north of Sahuarita to near Continental. The water levels in this area probably will be significantly lower than predicted by the model because, over the short term, most of the water will be produced from the coarse sediment west of the Santa Cruz fault. (See pls. 1 and 2, sections $E-E^{\prime}, G-G^{\prime}$, and $I-I^{\prime}$; Anderson, 1972.) Some water will drain from the silt and mudstone during the 1966-85 modeled period, but not as much as indicated by the model analysis.

Another area of faulty transmissivity pattern for the entire thickness of the aquifer is along the Santa Cruz River northwest of Tucson and along Rillito Creek, where the large transmissivity values are not representative of most of the saturated aquifer. The few tens of feet of saturated stream alluvium may have a transmissivity 5 to 10 times greater than that in the underlying Fort Lowell Formation and Tinaja beds, and the direct use of the transmissivity values from the aquifer tests gives too much emphasis to the stream alluvium. The stream alluvium is being drained by pumping, and following the draining, the water levels will drop more quickly than the model prediction because of the smaller transmissivity values for the lower part of the aquifer. The areas that will be soonest affected by a further water-level drop are where the 1966 water levels were about 50 feet below the land surface (pl. $4 A$ ).

A mathematical error in accounting for streamflow infiltration occurred in places where the stream alluvium was saturated and where the water level was within 50 feet of the surface in 1966 (pl. $4 A$ ). This error was created because the transmissivity of the alluvium was as much as five times larger in 1966 than the transmissivity of the entire saturated thickness of the aquifer and probably was even larger before that. The probable effect of the error is that the model-predicted water-level decline will be greater than the actual decline. (See the section entitled "Streamflow Infiltration and Recharge.")

The transmissivity pattern, other than along the streams, is reasonably representative of the transmissivity estimated on the 
basis of lithologic characteristics. The contour lines needed only slight revision to reflect more accurately the pattern of stream drainage into the central part of the basin and the beach-dune (?) deposit that bounds and locally overlaps the silt and clay of the Tinaja beds and the Fort Lowell Formation (pls. 1 and 2, section $E-E^{\prime}$, well (D-15-14) 25add; section $G-G^{\prime}$, well (D-16-14) 21dbb).

\section{STORAGE}

The quantity of ground water in storage is vastly greater than any part or sum of parts of the water budget for the Tucson basin, including annual streamflow, ground-water inflow and outflow, or cumulative 1940-65 ground-water pumpage. Virtually all the recoverable ground water in the basin is stored within the boundary of the aquifer (pl. 1). The volume of recoverable water was calculated to depths of 500 and 1,000 feet below the 1966 water table by computing the volume of aquifer that is dominantly sand or gravel and multiplying the volume by the estimated specific yield of the aquifer. The ground water in storage to a depth of 500 feet below the 1966 water table generally is suitable for drinking, but water from some of the deeper parts of the aquifer must be mixed with good-quality water to make it potable.

The area of the aquifer decreases with depth because the boundary slopes gently toward the center of the basin. Near the land surface, the boundary approximates the intersection of the water table with rocks of low permeability and porosity, and, at depth, the boundary is the contact between the Pantano Formation or younger sedimentary units and the older rocks. For purposes of computing the volume of ground water that can be withdrawn from storage, the aquifer was divided into eight segments (pl. $4 C$ ). The segments are bounded by the major faults, which control the distribution of nearly impermeable and permeable sediment. The volume of recoverable water was calculated in the segments or parts of segments where sand and gravel predominate; the volume of recoverable water was not calculated where nearly impermeable silty and clayey sediment is predominant. Although silt and clay store as much or more water than the more permeable sand and gravel, the yield to wells is so small and slow that pumping large quantities of water is impractical. Water drains slowly from the nearly impermeable sediment as water is withdrawn from the adjacent more permeable sediment, and the effect of the lateral leakage near the contact of the two units is a larger than calculated recovery of water from the permeable sediment.

The amount of recoverable ground water in the basin is calculated by treating the aquifer as though it were entirely unconfined; 
therefore, the specific yield is an approximation of the volume of recoverable water in storage. The specific yield is the ratio of the volume of water which the aquifer will yield by gravity to the volume of the aquifer. Expressed as a percentage, the specific yield is the difference between the porosity-assuming 100 percent saturation of the pore spaces in the aquifer-and the specific retention. The porosity is the ratio, in a unit volume of aquifer, of the volume of pore space to the volume of aquifer. Specific retention, also expressed as a percentage of a unit volume of aquifer, is the ratio of the volume of water retained against the pull of gravity to the volume of aquifer. The specific yield was derived by subtracting the estimated specific-retention values from the porosity values, which were measured by geophysical logs, and by a trialand-error simulation in the analog model.

The computed porosity of the aquifer ranges from 20 to 35 percent and averages about 28 percent of the aquifer volume to depths much greater than 1,000 feet below the 1966 water table. The porosity values were computed from borehole-density and sonic logs of wells (D-16-15) 5bcc, (D-16-15) 10ccc, (D-15-15) 16cbb, and D-14-14) 16ccc (pl. 1). The material tapped by these wells is regarded as representative of the part of the aquifer for which the specific yield was calculated.

Values of specific retention were estimated from specific-retention values for aquifers in other areas that have lithologies and textures similar to those of the Tucson basin aquifer (Johnson, 1966). The specific retention of the silty sand and coarser material in the Tucson basin was estimated to be about 10 percent. By subtracting the estimated specific-retention values from the computed porosity values, the specific yield was found to range from 10 to 25 percent. The data were too widely dispersed to compute changes in the specific yield from place to place and in depth; therefore, an approximate average specific yield of 15 percent was used. The 15-percent value is in conservative agreement with the values for similar aquifers (Johnson, 1966) that were used for comparison. As a result of ground-water withdrawal and concurrent water-level decline in the aquifer, an additional few percent of the water held in retention can be made available, owing to compaction of the aquifer.

The specific yield of 15 percent used in calculating storage was confirmed or checked by the analog model except in a 4-square-mile area in segment $\mathrm{V}$ (pl. $4 C$ ), where a specific yield of 4.5 percent was required in order to balance the recorded pumpage and measured water-level declines. The 4-square-mile area is surrounded by a 1-mile-wide zone, in which a specific yield of 7.5 percent was 
used (Anderson, 1972). The values of 4.5 and 7.5 percent may be accurate; however, because the aquifer characteristics in segment $\mathrm{V}$ do not appear to be substantially dissimilar from those in the rest of the basin, where a specific yield of 15 percent gave consistent results, it appears that other factors, such as pumpage or an incorrectly large transmissivity value, may have been responsible for the apparent anomaly. In addition, some of the waterlevel decline in segment $\mathrm{V}$ may have been caused by the tapping of deep aquifers, which contain water under less hydraulic head than that of the water near the surface (table 1). As discussed in the section "Ground-Water Pumpage and Water-Level Declines," the total historic pumpage in the 4-square-mile area may not be recorded, and, therefore, a specific yield of 15 percent was used in this report to estimate the volume of recoverable water.

Another source of error in the calculation of recoverable stored water is the arbitrary assignment of a 15 percent specific yield to the saturated stream alluvium-a value of 25 percent probably is more accurate. However, the volume of saturated stream alluvium is very small in comparison with that of the entire aquifer, and the error is not significant.

The total amount of recoverable water that is stored in all segments to a depth of 500 feet below the 1966 water table is about 30.5 million acre-feet. In contrast, the volume of water withdrawn from the upper part of the aquifer in 1940-65 probably was less than 2 million acre-feet. (See section "Ground-Water Pumpage and Water-Level Declines.") The most easily available water for the city of Tucson is stored in segments II, III, IV, and V, in which the recoverable volume to a depth of 500 feet below the 1966 water table was about 8.7 million acre-feet (pl. $4 C$ ). If water is withdrawn to a depth of 500 feet below the 1966 water table, the water level will then be between about 550 to 1,000 feet below land surface. The expected pumping levels will be from about 750 to 1,200 feet below the land surface, and the required well depths will be from about 1,000 to 1,500 feet. In addition, a 500-foot decline in water level will cause about 10 to 30 feet of land subsidence, depending on the compressibility of the aquifer.

The total amount of recoverable water that is stored in all segments from 500 to 1,000 feet below the 1966 water table is slightly more than 20 million acre-feet, but some of the deep water contains dissolved-solids and fluoride contents in excess of those recommended by the U.S. Public Health Service (1962) for drinking water. The chemical quality of the deep water can be upgraded by mixing the deep water with near-surface good-quality water. If water levels decline 1,000 feet below the 1966 water table, the 
depth to water will range from about 1,050 to 1,500 feet below the land surface. Pumping levels will be deeper than the depth to water, and land subsidence due to compression of the aquifer will be more than 30 feet. The total amount of recoverable water to a depth of 1,000 feet below the 1966 water table is slightly more than 50 million acre-feet.

\section{AQUIFER COMPACTION AND LAND SUBSIDENCE}

Some compaction of the aquifer and land subsidence will accompany ground-water pumping and water-level declines in the Tucson basin, although detrimental effects from land subsidence are minimal at the present time (1970). Because of the similarity of the Tucson basin aquifer to the aquifers in central Arizona, subsidence may be expected to become a serious problem and is discussed in some detail in this report. Subsidence is creating serious land-use problems in central Arizona (Schumann and Poland, 1970), where water-level declines are two to three times greater than in the Tucson basin. Withdrawal of ground water at the present rate in the Tucson basin probably will result in measurable land subsidence by 1985 . The areas of greatest potential land subsidence coincide generally with the areas of greatest waterlevel decline, but other factors, such as clay content and degree of lithification, tend to modify the response of the aquifer to applied stress. Earth fissures tend to develop between subsiding and nonsubsiding areas or between areas that are subsiding at different rates. Land subsidence, where it changes the slope of the land surface, affects all types of structures; buildings are damaged, and gradients are altered in canals. Where the land subsides differentially, fissures as much as 3 feet wide may develop, roadbeds may be offset, and waterlines, sewerlines, and gaslines may be broken.

Foundation failures in the Tucson area are sometimes ascribed to ground compaction due to ground-water withdrawal, but land subsidence and fissures also occur when unstable deposits are wetted and compacted, generally following a sudden or unusually great application of water to the land surface (Pashley, 1961, p. 98-101). Foundation failures probably owing to wetting and near-surface compaction in the Tucson area have been described by Platt (1963) and Lacy (1964). This subsidence is not due to compression of the aquifer and is described here only because the effect is similar to that caused by aquifer compaction. The amount of subsidence due to wetting is dependent on overburden load, natural moisture conditions, and the amount and type of clay in the compacting deposits (Bull, 1964). The amount of compaction 
increases with an increase in overburden load. The wetting lubricates adjacent grains in the soil and weakens the clay bond where voids exist, which enables shifting and closer packing of the grains. The result is land subsidence and (or) soil contraction accompanied by fissures (Bull, 1964, p. 62; Lofgren and Klausing, 1967). Sediment that contains a few percent to 30 percent clay compresses when wetted, and sediment containing about 12 percent clay is the most compressible (Bull, 1961, p. 188). The probability of subsidence due to surface wetting is difficult to predict without a detailed knowledge of soils but is most common on fans and flood plains and in newly irrigated or wetted areas. Low-density soils are most likely to rearrange and compact upon wetting (Lacy, 1964, p. 43-44).

Aquifer compaction, which causes land subsidence and its attendant side effects, results from compression of grains and reduction of intergranular spaces. The compression is caused by a decrease in buoyant support of the grains and by a change in hydrostatic pressure between the pores in grains and the voids between grains. A lowering of the water table or a decrease in artesian head causes rearrangement and closer packing of the coarse and essentially noncompressible grains and compression and partial dewatering of compressible minerals, such as montmorillonite clay. The compaction stress at depth may be increased if a decrease in artesian head at depth is accompanied by an increase in near-surface loading, as may be created by a near-surface water-level rise. The greater the clay content and void space between noncompressible grains, the greater is the potential for compaction of the material. In addition, montmorillonite clay, which is the typical interstitial clay of the sediment in the Tucson basin (Laney, 1972 ), is more compressible than other clay minerals (Gabrysch, 1967).

Land subsidence owing to ground-water withdrawal in the Tucson basin has not yet been documented by accurate land-level surveys. Some cracking of home foundations was noted by Platt (1963) in an area that approximately bounds the University terrace as mapped by Smith (1910) and Pashley (1966). Linear landsurface scars that coincide with old wagon and stage trails to Tucson and Fort Lowell probably were incorrectly ascribed to differential compaction or structural activity by Sherman and Hatheway $(1964$, p. 79-86). Although the amount of subsidence caused by compaction of the Tucson basin aquifer has not been documented, the approximate amount of subsidence to be expected per unit of water-level decline can be computed by comparing the aquifer with similar aquifers in areas where subsidence is being measured. 
Subsidence has been related to ground-water withdrawal in a volume to volume relation and to ground-water-level decline in a length to length relation. The two types of relation have been compared by use of the storage coefficient of the aquifer. The deposits in San Joaquin Valley, Calif., are similar to those in the Tucson basin, and the volume of subsidence in the southeastern part of the valley is equivalent to about 10 percent of the volume of ground-water withdrawal (Lofgren and Klausing, 1967). The volume of subsidence in west-central San Joaquin Valley is equivalent to from 5 to more than 30 percent of the withdrawal and averages 30 percent of the volume withdrawn in a 1,000-square-mile area (W. B. Bull, written commun., 1969). Northeast of Eloy in central Arizona, land subsidence was about 7.0 feet in 1905-64 in response to the 1923-64 water-level decline of about 200 feet (Schumann and Poland, 1970, p. 297, 298, fig. 3). The water-level decline was proportional to the volume of water removed in the Eloy area; assuming that the vertical subsidence was proportional to the volume of subsidence, the ratio of subsidence volume to pumpage volume is approximated by the relation between the vertical subsidence and the product of water-level decline and storage coefficient:

$$
\frac{\text { volume of subsidence }}{\text { volume of pumpage }}=\frac{\text { vertical subsidence }}{\text { water-level decline } X \text { storage coefficient }} \text {. }
$$

Recorded Eloy data and a storage coefficient of 0.15 (Hardt and Cattany, 1965, table 7) give the expression: 200 feet (water-level decline) $\times 0.15$ (coefficient of storage) $\times R$ (ratio of subsidence volume to pumpage volume) $=7.0$ feet (measured vertical subsidence). Solving for $R$ yields 0.23 , or 23 percent. Therefore, ignoring the effect of time, the vertical subsidence was equivalent to at least 23 percent of the vertical column of water removed in the Eloy area. Put another way, 23 feet of vertical land subsidence can be expected to result from a water-level decline of about 666 feet, which is equivalent in the Eloy area to withdrawal of a 100-foot column of water.

The areas of greatest potential land subsidence in the Tucson basin are the areas of large water-level decline in the T. $14 \mathrm{~S}$, R. 14 E., urban area and in the irrigated lands along the Santa Cruz River near Sahuarita. The subsidence is termed potential because of doubt concerning its occurrence and lack of knowledge of the lag-time between decline and subsidence. The storage coefficient is about 0.15 , and the water-level decline in both areas was 60-70 feet in 1940-64, which gives a subsidence potential computed from the water-level decline of about 1 to 3 feet. A calculation based on pumpage values gives similar results. The recorded 
ground-water withdrawal for the T. 14 S., R. 14 E., urban area (pl. $4 B$ ) was 10 to 20 acre-feet per acre, which is equivalent to the removal of a 10 - to 20 -foot vertical column of water; if the subsidence is assumed to be 10 percent of the water column, then the subsidence potential is 1 to 2 feet. The subsidence potential probably is greater in the urban area than along the major stream channels because the dewatered part of the aquifer in the urban area contains more clay and because the water level rises intermittently along the stream channels. A rise in water level or artesian head tends to slow or reverse subsidence due to compaction (Bull, 1968).

The aquifer system is most susceptible to compaction where it is clay-rich but permeable enough that substantial amounts of water can be withdrawn. This situation exists in the uppermost part of the aquifer in an area that surrounds the Tucson municipal airport in the northern part of T. 15 S., R. 14 E., and in the lower part of the aquifer in a zone adjacent to the fault-bound depression in the south-central part of the basin (pl. 1). Although groundwater withdrawal and water-level declines are minimal in these areas at the present time, significant land subsidence can be expected to result from substantial ground-water withdrawal.

The area of greatest potential differential subsidence resulting from unequal compaction is along the trace of the Santa Cruz fault ( $p l .1$ ), where the aquifer to the east is clay-rich and can be dewatered. Because the aquifer to the west contains less clay and is more firmly cemented, it probably will not subside as much. Other fault traces in the central part of the basin also may be loci for differential subsidence and fissures offsetting the land surface.

\section{STREAMFLOW}

Streams of the Tucson basin are typical of those in other arid and semiarid lands, where the channels are dry for long periods of time. The flows generally are confined to the channels, although they frequently inundate the flood plains where the channels are not deeply incised. Most of the streamflow in the basin is direct runoff from rainfall, and ground water sustains flow in only a few places. According to Condes de la Torre (1970), streamflow is so variable that the standard deviation of annual runoff approximates or exceeds the mean, which indicates that extreme values influence the mean. Because unusual storm events are the source of flow, statistical measures, such as probability of flow and frequency of occurrence of flow volumes, are necessary to describe streamflow. Condes de la Torre (1970) used data from 15 gaging stations in the upper Santa Cruz River basin to analyze stream- 
flow, and his daia have been used in this report. The length of record for the stations ranged from 6 to 60 years.

The Santa Cruz River is dry most of the time in the Tucson basin, and the median number of days per year of no flow past the several stations is about 320 to 330 . The median number of days per year of no flow in Rillito Creek is about 335. Streams nearer the mountains than the Santa Cruz River also are dry for long periods. Rincon Creek (pl. 3) can be expected to be dry about 250 days per year, and Sabino Creek, about 50 days per year. Pantano Wash at the gaging station near Vail generally has flow because ground water is forced to the surface by a bedrock barrier. A short distance downstream from the gage, the flow infiltrates the streambed, and the periods of no flow in the ungaged part of Pantano Wash probably closely match those of the Santa Cruz River and Rillito Creek. For a 20-year recurrence interval, the number of days of no flow in any one year would exceed 345 days for the Santa Cruz River, about 350 for Rillito Creek, about 330 for Rincon Creek, and 120 for Sabino Creek.

Floodflow in the streams is mainly the result of thunderstorms, which occur with more regularity than frontal storms. Summer floods are more common than winter floods, and for the periods of record (1915-65 and 1949-65), more than 93 percent of the flood peaks along the Santa Cruz River occurred in July, August, and September. Floods in Sabino Creek were more evenly distributed because the drainage area extends high into the Santa Catalina Mountains, where precipitation is more frequent and abundant and is complemented by snowmelt. The Santa Cruz River and Rillito Creek had flows greater than 1 cfs (cubic foot per second), or $0.65 \mathrm{mgd}$ (million gallons per day), 8 to 13 percent of the time and greater than $65 \mathrm{mgd}$ only 2 to 4 percent of the time (table 2). The principal tributaries to Rillito Creek-Rincon and Sabino Creeks and Pantano Wash-had flows greater than $0.65 \mathrm{mgd} 17$ to 90 percent of the time and greater than $65 \mathrm{mgd}$ only 0.5 to 2 percent of the time. During periods of flow, the median of all mean

TABLE 2. - Frequency of discharge and flow rate for the Santa Cruz River and for Rillito, Rincon, and Sabino Creeks and Pantano Wash, 1936-63

\begin{tabular}{|c|c|c|c|c|c|c|}
\hline \multirow{2}{*}{ Stream } & \multicolumn{4}{|c|}{$\begin{array}{l}\text { Percentage of time indicated mean daily } \\
\text { discharge is exceeded for specifled flows }\end{array}$} & \multicolumn{2}{|c|}{$\begin{array}{l}\text { Rate of flow } \\
\text { (median of all mean } \\
\text { daily discharges } \\
\text { greater than 0) }\end{array}$} \\
\hline & $\begin{array}{l}0.65 \mathrm{mgd} \\
(1 \mathrm{cfs})\end{array}$ & $\begin{array}{l}6.5 \mathrm{mgd} \\
(10 \mathrm{cfs})\end{array}$ & $\begin{array}{l}65 \mathrm{mgd} \\
(100 \mathrm{cfs})\end{array}$ & $\begin{array}{c}650 \mathrm{mgd} \\
(1,000 \mathrm{cfs})\end{array}$ & $\begin{array}{l}\text { Million } \\
\text { gallons } \\
\text { per day }\end{array}$ & $\begin{array}{l}\text { Cubic feet } \\
\text { per second }\end{array}$ \\
\hline 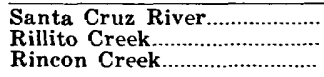 & $\begin{array}{r}9-13 \\
8 \\
17\end{array}$ & $\begin{array}{r}6-9 \\
5 \\
7\end{array}$ & $\begin{array}{r}3-4 \\
2 \\
.5\end{array}$ & $\begin{array}{c}0.5-0.8 \\
.15 \\
\text { No recorded }\end{array}$ & $\begin{array}{l}14 \\
15 \\
.8\end{array}$ & $\begin{array}{c}21 \\
23 \\
1.3\end{array}$ \\
\hline $\begin{array}{l}\text { Sabino Creek } \\
\text { Pantano Wash }\end{array}$ & $\begin{array}{l}43 \\
90 \\
\end{array}$ & $\begin{array}{r}17 \\
5\end{array}$ & $\begin{array}{l}2 \\
1\end{array}$ & $<.1$ & $\begin{array}{l}.6 \\
.8 \\
\end{array}$ & $\begin{array}{l}1.0 \\
1.3\end{array}$ \\
\hline
\end{tabular}


daily discharges was 0.6 to $0.8 \mathrm{mgd}$ in Sabino Creek, Pantano Wash, and Rincon Creek and $15 \mathrm{mgd}$ in Rillito Creek (table 2). The peak discharges along the Santa Cruz River ranged from a median of $5,000 \mathrm{cfs}$ to a median of $7,000 \mathrm{cfs}$ on a per annum basis and were about $15,000 \mathrm{cfs}$ in any 10-year period and about 30,000 cfs in any 50-year period. The duration of a normal flood event in the main streams was less than 3 days. The median volume of flow during these events was about 2,800 to 6,600 acre-feet along the Santa Cruz River and 2,200 acre-feet in Rillito Creek; the minimum volume approached zero, and the maximum volume at the Tucson gage on the Santa Cruz River was 41,500 acre-feet and in Rillito Creek was 23,900 acre-feet.

The average yearly flow in the Santa Cruz River (20-22 years of record) ranged from about 12,000 acre-feet at the south edge of the basin to almost 20,000 acre-feet at Cortaro (pl. 7). The average annual flow in Rillito Creek for 1908-65 was about 12,000 acre-feet, and that in Sabino Creek (40 years of record) was about 8,000 acre-feet. Flow in Pantano Wash at the east edge of the basin averaged about 5,000 acre-feet per year during 1959-65; nearby Rincon Creek flowed at an average rate of almost 3,000 acre-feet per year during 1952-65. As noted previously, flow in these streams is extremely variable, and a very large part infiltrates (pl. 7) the streambeds and ultimately reaches the groundwater reservoir.

Although large amounts of water occasionally flow in the streams, the entrapment of flow for public supply would probably require more storage space than is economically justifiable. To evaluate the supply potentially available on the Santa Cruz River and on Rillito and Sabino Creeks, Condes de la Torre (1970) computed the maximum storage space necessary to sustain an arbitrary $3.23 \mathrm{mgd}$ ( $5 \mathrm{cfs}$ ) withdrawal rate through a drought equally as severe as the most severe drought for 1936-63; the withdrawal rate is arbitrary and not necessarily the most efficient because more practical schemes of operation might use either "as available" withdrawals of water at a greater discharge rate or other options. The computation did not consider assured losses to infiltration or evaporation or loss of storage space owing to silting, all of which would significantly diminish the 5-cfs withdrawal rate. The approximate storage space needed on the Santa Cruz River near Tucson would be 6,500 acre-feet, on Rillito Creek 8,700 acre-feet, and on Sabino Creek 5,000 acre-feet.

\section{CHEMICAL QUALITY OF WATER}

The chemical quality of the ground water and surface water in the Tucson basin is acceptable for most uses. The quality-of-water 
data in this report were summarized from work by Laney (1972). Although the ground water is moderately hard to very hard in most of the basin, most of it contains less than $500 \mathrm{mg} / \mathrm{l}$ dissolved solids to depths of 1,000 feet or more (pl. $6 A$ ). In most of the basin, the dissolved-solids concentration in ground water ranges from about 250 to $1,500 \mathrm{mg} / \mathrm{l}$, but locally, concentrations are as great as $3,000 \mathrm{mg} / \mathrm{l}$. The dominant ions in the ground water in the upper part of the aquifer are calcium, sodium, and bicarbonate; at depth the dominant ions are sodium, bicarbonate, and sulfate. In several places ground water in the upper part of the aquifer contains anomalous concentrations of dissolved solids comprising mainly calcium, sodium, sulfate, chloride, fluoride, and nitrate. The calcium and nitrate are associated chiefly with infiltration of streamflow, and the sodium, sulfate, chloride, and fluoride are from the deeper part of the aquifer. Streamflow generally contains less than $400 \mathrm{mg} / \mathrm{l}$ dissolved solids, and the principal ions are calcium and bicarbonate. Most floodflows carry substantial volumes of sediment, which complicate or may invalidate economic design of structures for flood control and water storage.

Water temperatures in the upper few hundred feet of the aquifer are about $77^{\circ} \mathrm{F}\left(25^{\circ} \mathrm{C}\right)$, and at depths of about 2,000 feet the water temperature may be as much as $130^{\circ} \mathrm{F}\left(54.5^{\circ} \mathrm{C}\right)$. The water temperature increases about $3^{\circ} \mathrm{F}\left(1.67^{\circ} \mathrm{C}\right)$ per 100 feet of depth. The hotter water occurs in wells near faults, which indicates upward leakage and circulation of hotter water along the fault zones. Smith (1910, p. 188) noted that infiltrating streamflow cools ground water in the deposits underlying Rillito Creek by $2^{\circ}$ to $5^{\circ} \mathrm{F}\left(1.1^{\circ}\right.$ to $\left.2.8^{\circ} \mathrm{C}\right)$ in the winter and warms it $2^{\circ} \mathrm{F}\left(1.1^{\circ} \mathrm{C}\right)$ in the summer.

Dissolved-solids concentrations in ground water in the northeastern half of the basin generally are less than $300 \mathrm{mg} / \mathrm{l}(\mathrm{pl} .6 A)$, and the water is only moderately hard (pl. $6 B$ ). The aquifer in this area contains a preponderance of granitic detritus derived from the Santa Catalina and Rincon Mountains. To the southwest, dissolved-solids concentrations increase to more than 300 but less than $500 \mathrm{mg} / \mathrm{l}$, and the water is hard. The aquifer in this area has a mixture of mafic to felsic rock types as detritus. Throughout the basin, dissolved-solids concentrations generally are not greater than $500 \mathrm{mg} / \mathrm{l}(\mathrm{pl} .6 \mathrm{~A})$ where the aquifer is sand or gravel; however, known concentrations range from 500 to about $3,000 \mathrm{mg} / \mathrm{l}$ where the aquifer is dominantly a clayey silt or mudstone. Water in the deeper part of the aquifer generally is softer because of the increase in sodium and the decrease in calcium, but the calcium content and hardness increase in places where clayey silt or mud- 
stone is dominant. The concentrations of dissolved solids in streamflow usually are less than $400 \mathrm{mg} / \mathrm{l}$ and commonly are less than $200 \mathrm{mg} / \mathrm{l}$; the water is moderately hard.

Rillito Creek, Pantano Wash, and the Santa Cruz River south of Sahuarita are underlain to depths as great as 400 feet by hard water that contains more calcium (pl. 6B) and dissolved solids (pl. 6A) than the ground water on either side of or below the more mineralized water. The calcium probably originates from processes associated with infiltration of streamflow, in which calcium and bicarbonate are the dominant dissolved constituents. Anomalously high nitrate concentrations of 5 to $30 \mathrm{mg} / \mathrm{l}$ roughly match the increase in dissolved-solids concentration along the Santa Cruz River. Generally, the nitrate probably is derived from decayed organic material, which in arid lands is most abundant along stream courses. The greatest concentrations of nitrate are along the river near Sahuarita, where irrigation return water may contribute additional nitrate, and northwest of the mouth of Rillito Creek, where infiltration of irrigation water and city of Tucson sewage effluent may be additional sources.

Chloride concentrations are less than $10 \mathrm{mg} / \mathrm{l}$ in ground water in most of the basin, but in a narrow belt along the Santa Cruz River from Sahuarita to Rillito concentrations commonly range from 30 to $130 \mathrm{mg} / \mathrm{l}$; the maximum concentration is about 400 $\mathrm{mg} / \mathrm{l}$. Sodium, sulfate, and fluoride concentrations are similarly greater than normal in this belt (pl. 6B). The anomalous concentrations of chloride, sodium, and sulfate probably are derived from upward leakage of deep water along the Santa Cruz and associated faults.

Water in the upper part of the aquifer contains less than 0.5 $\mathrm{mg} / \mathrm{l}$ fluoride in most of the basin, but in a few areas the water contains anomalous concentrations of 0.5 to about $1.5 \mathrm{mg} / \mathrm{l}$. The anomalous concentrations of fluoride occur because of upward leakage of ground water, and they roughly coincide with the anomalous concentrations of chloride. The fluoride concentration in water at depths of 1,000 feet or more below the land surface ranges from 1 to $5 \mathrm{mg} / 1$ in most wells; the maximum recorded concentration is $11 \mathrm{mg} / \mathrm{l}$ (Laney, 1972).

Water in the area that extends northwestward across the basin from Vail to the center of Tucson contains anomalously high concentrations of sulfate and calcium. The calcium and sulfate contents are greatest in water at depths of 500 to 700 feet below the surface. The ions may be derived by leaching of gypsum or anhydrite and are carried by water moving downgradient to the northwest (Laney, 1972). 
Sediment concentrations in streamflow range from $460 \mathrm{mg} / 1$ in Tanque Verde Creek to nearly $46,000 \mathrm{mg} / \mathrm{l}$ in the Santa Cruz River. The large sediment concentrations carried by $1,000 \mathrm{cfs}$ or more of flow are equivalent to transport rates of 100,000 to about 700,000 tons of sediment per day. In most of the basin the annual sediment yield ranges from 0.2 to 0.5 acre-feet per square mile (William Mildner, Soil Conservation Service, written commun., 1968).

In summary, the chemical quality of the ground water in the basin is acceptable for most uses; the water in the lower part of the aquifer generally is softer than that in the upper part, but at a depth below about 1,000 feet the fluoride content may be great enough to require mixing of the water with water of better quality before use as a public supply. The soft water, which contains more than $1.0 \mathrm{mg} / \mathrm{l}$ fluoride, is satisfactory for most industrial uses, and many of the industrial plants in the area use water from the lower part of the aquifer. The water of poorest quality for public supply is at shallow depths along the Santa Cruz River from Sahuarita to Rillito and along the zone that trends northwestward across the central part of the basin, where the water contains anomalously high concentrations of calcium and sulfate. The poorer quality of water at depth is associated entirely with the clayey silt and mudstone facies and with faults that may serve as conduits for water dissolving soluble ions from the mudstone beds. Streamflow is of good chemical quality, but the nature of its occurrence and the sediment load make direct use or storage financially impractical.

\section{WATER BUDGET}

Within the scope of this report, the water budget is the annual volume of water that moves into and out of the aquifer and into and out of the major stream channels. Water is recharged to the aquifer within the basin and along the perimeter and is discharged by underflow out of the basin at Rillito, by consumptive use of pumpage, and by evapotranspiration along streams. Streamflow enters the basin in the Santa Cruz River and its major tributaries; most of the flow infiltrates the streambeds, and the remainder flows out of the basin at Rillito.

The inflow, or recharge, to the aquifer (pl. 7) amounts to about half the sum of the natural outflow and the total consumptive use. The amount of streamflow that leaves the basin is equivalent to about 10 percent of the total discharge from the aquifer. About 75 percent of the streamflow in the main stream channels in the basin infiltrates to the aquifer ( $\mathrm{pl} .7$ ). 


\section{AQUIFER RECHARGE}

The main source of recharge to the aquifer is streamflow that infiltrates along the major channels. The next largest source of recharge is ground water that enters along the perimeter of the aquifer. A third substantial source is ground water that enters the aquifer as underflow in the valleys of Canada del Oro and the Santa Cruz River. In addition, some of the water pumped for irrigation, public supply, and industrial use is returned to the aquifer. The sources and volumes of inflow are discussed in the following sections in the order of their simulation by or derivation from the analog model.

\section{UNDERFLOW}

Underflow into the aquifer was calculated for the areas where the aquifer is arbitrarily bounded by water-bearing permeable deposits and where the water-level gradient and the aquifer thickness indicate a substantial flow of ground water into the basin. The known areas of underflow are at the south edge of the aquifer in the valley of the Santa Cruz River and at the north edge of the aquifer in the Canada del Oro. The underflow from the gap between the Sierrita and Tucson Mountains is negligible because the ground-water divide is at approximately the same location as the surface-water divide (pls. 1 and 3), and, therefore, little or no underflow enters the basin from Avra Valley. The only other topographic gap that may permit underflow between bounding mountains is occupied by Pantano Wash between the Empire and Rincon Mountains. However, the water-level contours in this area indicate recharge that is not particularly controlled by the channel of Pantano Wash, and the possible underflow through this topographic breach is included in mountain-front recharge.

The underflow into the aquifer at the south edge of the basin is about 10,000 acre-feet per year, and underflow at the north edge is about 7,800 acre-feet per year (Anderson, 1972). The cross section at the south edge of the basin consists of a section trending east along the county line joined by a section trending north to the south edge of the Sierrita Mountains (pl. 7). The east-trending leg is 11 miles long, the water-level gradient is 25 feet per mile, and the estimated average transmissivity is 33.6 acre-feet per year per foot of aquifer (30,000 gpd per $\mathrm{ft})$. The underflow is :

$$
33.6 \times 11 \times 5,280 \times \frac{25}{5,280}=9,200 \text { acre-feet per year. }
$$

The north-trending leg is 5 miles long, the water-level gradient is 25 feet per mile, and the estimated average transmissivity is 11.2 
acre-feet per year per foot of aquifer $(10,000 \mathrm{gpd}$ per $\mathrm{ft})$. The underflow is:

$$
11.2 \times 5 \times 5,280 \times \frac{25}{5,280}=1,400 \text { acre-feet per year. }
$$

The total calculated underflow is 10,600 acre-feet per year; an inflow of 10,000 acre-feet per year (pl. 7) provided the best match between the modeled and the actual water-level gradient (Anderson, 1972). The cross section at the north edge of the basin is about $41 / 2$ miles long, the gradient is 50 feet per mile, and the estimated average transmissivity is 33.6 acre-feet per year per foot of aquifer $(30,000 \mathrm{gpd}$ per $\mathrm{ft})$. The approximate underflow is:

$$
33.6 \times 4.5 \times 5,280 \times \frac{50}{5,280}=7,600 \text { acre-feet per year. }
$$

An inflow of 7,800 acre-feet per year (pl. 7) provided the best match between the modeled and the actual water-level gradient (Anderson, 1972).

\section{RECHARGE ALONG THE MOUNTAIN FRONTS}

The estimate of recharge to the aquifer along its perimeter is an empirical solution derived from the analog model. The recharge is direct underflow to the basin aquifer from joints and other openings in the rocks of the mountains and infiltrated water from the many small stream channels that drain the mountains. The perimeter recharge was calculated from the amount of electrical energy required to simulate the measured water-level gradient in 1940 , a time when the aquifer was not under any significant manmade stress - that is, outflow was equal to inflow, and there was no significant change in storage. Anderson (1972) called this year the steady-state, or equilibrium, period. Recharge under steadystate conditions was assumed to be approximately equivalent to the long-term mean annual recharge.

The mean annual recharge along the Sierrita, Santa Rita, Rincon, Tanque Verde, Santa Catalina, and Tortolita Mountains ranges from 180 to 325 acre-feet per mile of perimeter per year measured along the boundary of the aquifer (pls. 1 and 7). No recharge is detectable along the Black or Tucson Mountains. The calculated mean annual recharge is 4,000 acre-feet along the Sierrita Mountains; 7,400 acre-feet along the Santa Rita Mountains; 12,600 acre-feet along the Rincon, Tanque Verde,' and Santa Catalina Mountains; and 4,000 acre-feet along the Tortolita Mountains (pl. 7). 
The recharge along the Tanque Verde and Santa Catalina Mountains from Tanque Verde Creek to Ventana Canyon (pls. 1 and 7) may be larger than that indicated by the steady-state simulation because the simulation did not include the ground water lost by evapotranspiration. In the analog-model analysis the losses to evaporation and to transpiration by phreatophytes in this area were assumed to be met by water infiltrated along the streams. The vegetation in the area $(1968-70)$ is comparable to the cover that existed in the equilibrium period; the sum of the estimated annual evapotranspiration and the estimated annual ground-water recharge from the infiltration required for the storage-depletion analysis to simulate the actual water levels in the area is larger than the average annual infiltration. The apparent imbalance, or deficiency in infiltration, is assumed to be equated by an additional perimeter recharge, which was not simulated in the steady-state model. An addition of about 2,800 acre-feet per year of perimeter recharge is required to adjust the imbalance; therefore, the recharge per mile of perimeter in some of the Tanque Verde Creek to Ventana Canyon area may be as great as 600 acre-feet per year. The estimated mean annual recharge along the entire perimeter of the aquifer is 28,000 acre-feet (Anderson, 1972) plus the 2,800 acre-feet not simulated in the steady-state model, or about 31,000 acre-feet.

\section{STREAMFLOW INFILTRATION AND RECHARGE}

Although the streams in the Tucson basin are dry for long periods each year, they transport volumes of water that are significant in terms of water use, and large quantities of streamflow infiltrate the streambed alluvium (pl. 7). Much of the water that infiltrates the streambed alluvium is recharged to the underlying aquifer; the nature of the mechanism of infiltration has been described by Smith (1910), Turner and others (1943), Schwalen and Shaw (1957), and Matlock, Schwalen, and Shaw (1965) mainly through computations of streamflow losses and through correlations of water-level rises in wells with floodflows in nearby stream channels. In these calculations the volume of water added to ground-water storage could only be approximated because of the uncertainty regarding the porosity and antecedent water content of the partially saturated material overlying the aquifer-items necessary to convert water-level rise into volume of water. Using neutron-moisture borehole logs, Wilson and DeCook (1968) showed that about a third of the floodwater that infiltrates the bed of the Santa Cruz River is promptly added to ground-water storage but that the remainder may take more than 6 months to reach the water table. 
As part of the Tucson basin study, Burkham (1970) calculated infiltration volumes along the major streams by relating infiltration rates to flow rates for each stream and applying the average relation to curves showing the frequency of flow rates. The frequency curves for measured flows were developed and adjusted to the 1936-63 base period (Condes de la Torre, 1970); the frequency curves for ungaged flows were derived by use of correlation techniques (Burkham, 1970). The method for calculating infiltration yielded an average annual infiltration volume for the main channels in the Tucson basin for the 1936-63 period. In the analog-model simulation the average infiltration values for 1936-63 were adjusted to an annual basis by comparison of the measured annual outflows from specific drainages with the average annual outflow resulting from Burkham's infiltration calculations. Burkham's (1970) basic formula for the relation between infiltration and inflow rates for reaches of streams in the Tucson basin is:

where

$$
\text { Infiltration rate }=C \times L \times \text { inflow rate } \text { re.s }^{0.8}
$$

$L=$ length of the reach, and

$C=$ a variable coefficient that is derived or estimated for a specific reach.

The coefficient, $C$, is not linearly proportional to the infiltration-inflow relation on a per mile basis because $C$ also varies with the length of the reach (Burkham, 1970). In addition the infiltrationinflow relation is an average for the whole reach, but the infiltration rate may vary significantly along individual parts of the reach. Nevertheless, the coefficient, $C$, gives an indication of the relative effectiveness of each channel reach as an artificial or natural recharge conduit.

According to Burkham (1970), the mean annual infiltration for 1936-63 along the Santa Cruz River, Canada del Oro, and Pantano Wash ranged from about 80 to 480 acre-feet per mile, and the approximate coefficient, $C$, for the rate per mile of channel ranged from about 0.06 to 0.18 (table 3 ). The mean annual infiltration along the Santa Cruz River, including a short reach of Rillito Creek, for 1936-63 was nearly 23,000 acre-feet; Pantano Wash and its tributary Rincon Creek infiltrated an average of 8,660 acre-feet annually, and Canada del Oro and Big Wash infiltrated 4,050 acre-feet annually. The mean annual infiltration along Rillito and Tanque Verde Creeks was about 15,300 acre-feet. The mean annual infiltration along Canada del Oro, Rillito Creek, Tanque Verde Creek and parts of Sabino Creek and Agua Caliente Wash, and Rincon Creek ranged from 295 to 820 acre-feet per mile, and the 
TABLE 3. - Mean annual infiltration volumes along the Santa Cruz River and its tributaries, 1936-63

\begin{tabular}{|c|c|c|c|c|}
\hline \multirow[b]{2}{*}{ Reach } & \multirow{2}{*}{$\begin{array}{l}\text { Length of } \\
\text { reach } \\
\text { (miles) }\end{array}$} & \multirow{2}{*}{$\begin{array}{l}\text { Coefficient, } C \text {, } \\
\text { per mile } \\
\text { of channel }\end{array}$} & \multicolumn{2}{|c|}{ Mean annual infiltration } \\
\hline & & & $\begin{array}{c}\text { Acre-feet } \\
\text { per mile }\end{array}$ & $\begin{array}{r}\text { Total (acre- } \\
\text { feet per year) }\end{array}$ \\
\hline $\begin{array}{l}\text { Santa Cruz River from the Pima County } \\
\text { line to Continental.... }\end{array}$ & 10 & 10.06 & 320 & 3,200 \\
\hline $\begin{array}{l}\text { Santa Cruz River from Continental } \\
\text { to Tucson. }\end{array}$ & 28.5 & & & \\
\hline $\begin{array}{l}\text { Santa Cruz River from Tucson to Cortaro } \\
\text { and Rillito Creek from the Tucson }\end{array}$ & 28.5 & .06 & 320 & 9,030 \\
\hline gage to the Santa Cruz River. & 16.6 & .11 & 480 & 8,030 \\
\hline Rillito... & 5.5 & 1.11 & 480 & 2,640 \\
\hline $\begin{array}{l}\text { Pantano Wash from Vail to Rillito } \\
\text { Creek }\end{array}$ & 21.5 & 1.11 & 240 & 5,160 \\
\hline $\begin{array}{l}\text { Rincon Creek from gage to Pantano } \\
\text { Wash. }\end{array}$ & 7.8 & 1.32 & 450 & 3,500 \\
\hline $\begin{array}{l}\text { Tanque Verde Creek from gage to } \\
\text { Sabino Canyon road and lower reaches } \\
\text { of Sabino Creek and Agua Caliente } \\
\text { Wash..... } \\
\text { Rillito and Tanque Verde Creeks from }\end{array}$ & 17.5 & 1.18 & 430 & 7,540 \\
\hline $\begin{array}{l}\text { Rillito and Tanque Verde Creeks from } \\
\text { Sabino Canyon road to the Tucson } \\
\text { gage on Rillito Creek... } \\
\text { Canada del Oro from the Pjua County }\end{array}$ & 9.5 & .18 & 820 & 7,780 \\
\hline $\begin{array}{l}\text { Canada del Oro from the Pima County } \\
\text { line to the mouth of Big Wash....... } \\
\text { Big Wash and lower Canada del Oro }\end{array}$ & 9.2 & 1.18 & 295 & 2,710 \\
\hline 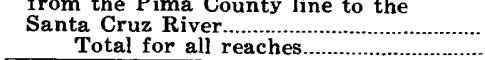 & 16.8 & 1.06 & 80 & $\begin{array}{r}1,340 \\
.50,930\end{array}$ \\
\hline
\end{tabular}

${ }^{1}$ Estimated.

approximate coefficient, $C$, for the rate per mile of channel ranged from 0.18 to 0.32 (table 3 ). The coefficient, $C$, was two to four times greater than that along most of the Santa Cruz River, but the infiltration volumes per mile were comparable because the Santa Cruz River had more flow. The total mean annual infiltration from the major streams in the Tucson basin in the 1936-63 base period was about 51,000 acre-feet (table 3 ). The annual infiltration volumes used to restrict the analog-model solution and justification ranged from about 24,000 to nearly 110,000 acre-feet. Burkham (1970) stated that the extremes in the annual infiltration volumes in each reach of stream channel probably ranged from nearly zero to more than four times the mean.

The mean annual infiltration volumes are approximately proportional to the mean annual streamflow volumes because of the relation between infiltration and flow rates. Except at Rillito Creek, the streamflow for the 1936-63 base period was from slightly less to 15 percent less than the measured streamflow for the entire period of record at the gaging stations ; at Rillito Creek the streamflow was nearly 50 percent less than the mean annual streamflow for the 57-year period of record ( $\mathrm{pl} .7$ ). Therefore, the long-term mean annual infiltration along the reaches of the channels probably is slightly greater than the mean annual infiltration for the base period, and the infiltration along Rillito Creek may be significantly greater. For the basin, as defined in this report, the mean annual infiltration for the 1940-46 and 1952-68 water years 
(October through September) was computed from data of B. N. Aldridge and S. G. Brown (written commun., 1969) and was about 58,000 acre-feet. This value is reasonably close to the mean volume of 51,000 acre-feet used in this investigation.

Unfortunately, the infiltration volume that is recharged to the aquifer cannot be measured directly except in very small areas. Some of the infiltrated water is evaporated from the near-surface material of the streambed, and some is transpired by plants growing along the streams. An accurate estimate of the remainder depends on an accurate knowledge of pumpage, preexisting moisture content of the soil, and the storage and transmissive properties of the aquifer. Because of inadequate knowledge of some or all of these items, the computed infiltration volumes can be used only to approximate the maximum amount that possibly can be recharged to the aquifer along the streams.

Some inconsistencies exist between the estimated totals of infiltration and the totals necessary for analog-model solution of the water budget. The probable long-term recharge derived from infiltration was estimated by use of the analog model and intuitive reasoning. Because of practical considerations dictated by completion time and constructional difficulties, the analog model was constructed as a one-layer model-that is, storage and transmissivity of the aquifer were modeled at one value for the entire thickness of the aquifer. In addition, model techniques required generalization of recharge-input values, and it was impractical to model temporal or localized recharge accurately. The model failed to simulate the interaction of the streamflow system and the aquifer because (1) the material that underlies the streambeds has a greater transmissivity and storage capacity than the main part of the aquifer, and (2) recharge to the aquifer along the streams is temporal, extremely variable, and localized in extent. Thus, the analog-model simulation required generalizations to such an extent that no unique solution could be obtained. This inherent difficulty will become less of a problem as water levels recede to a plane where the temporal and localized nature of the recharge will be naturally averaged and to where the transmissivity and storage capacity are more uniform and more accurately reflected by the generalizations used in construction of the analog model. To solve the analog by trial-and-error methods, the model required a total recharge input of nearly 52,000 acre-feet per year along the major streams in 1963-64. The computed average infiltration for 1963-64 was about 59,000 acre-feet; however, along reaches of the Santa Cruz River and Rillito Creek, the aquifer required more recharge than the computed infiltration. This discrepancy probably indi- 
cates that the specific yield of 15 percent that was used in the construction of the model was too low where water levels were in or near the stream alluvium (pl. 2). Neutron-moisture logs (Wilson and DeCook, 1968) from boreholes in a small area along the Santa Cruz River indicate that the correct value for the alluvium probably is about 25 percent. In addition, the transmissivity of the alluvium probably is much higher than that of the underlying aquifer, which created a possible large error in the steadystate simulation of recharge along the streams. Because of the variables inherent in modeling this part of the system, recharge from infiltration was estimated by considering the physics of flow through unsaturated material, the depth to water, and the probable loss of infiltrated water to evapotranspiration.

The amount of recharge along the major streams probably is equivalent to at least 90 percent of the amount of infiltrated water, and in places where the water level is deep enough not to interfere with the infiltration rate and where the rate is great, recharge probably approaches 100 percent of the infiltration. A similar conclusion was presented in previous reports (Turner and others, 1943 , p. 45, 47; Burkham, 1970). Thus, the mean annual recharge along the streams was estimated to be about 45,000 to 51,000 acrefeet, and the probable range of annual recharge in 1940-64 was about 24,000 to 100,000 acre-feet. Because the mean annual infiltration through 1968 is greater than that in the base period through 1963, the larger value of 51,000 acre-feet is taken as the mean annual recharge, and the range of 24,000 to 100,000 acrefeet per year is taken as the range of recharge in the "Budget Summary" of this report.

IRRIGATION, SEWAGE, AND INDUSTRIAL RETURN WATER

The measured water-level declines in irrigated areas for most of 1940-65 were less than the declines simulated in early trialand-error runs of the model (Anderson, 1972), in which only the computed recharge along the streams and aquifer perimeter was utilized. The lack of correspondence between the actual and modeled declines was evident in 1940-57. The most likely cause of the discrepancy was either overestimation of pumpage or return of irrigation water to the aquifer. No basis existed for altering the pumpage estimation; a 25-percent return of irrigation water was necessary for this period in order to match the simulated and actual water-level declines. Adjustment was not required after 1957, which implies that the return of irrigation water was small in 1958-65; the lack of detectable return of irrigation water in 1958-65 may have been due to increased efficiency in the use of 
irrigation water or to more accurate pumpage records. The same response also could have been due to an underestimate of pumpage or, less probably, to an increase in the aquifer storage coefficient with depth.

The size of a possible quantitative error in irrigation return is difficult to determine because the lack or presence of return was not documented by any direct-measurement method, such as moisture measurements from the land surface to the water table. Normally, in the local irrigated areas, water in excess of the moisture-retention capacity of the soil is applied to flush out salts which are concentrated by the evaporation of irrigation water. The water flushes salt accumulations out of the plant-root zone and moves the salts downward; if flushing does not occur, the soluble-salt content of the soil increases and retards plant growth. According to L. C. Halpenny (written commun., 1970), soluble salts are not increasing in the soil in the irrigated areas in the Tucson basin. This indicates that at least some of the irrigation pumpage must be flushing through the soil of the plant-root zone and presumably is percolating downward to the aquifer.

Sewage effluent from the city of Tucson sewage plant has been used for irrigation or discharged directly to the bed of the Santa Cruz River for many years. The total amount of effluent ranged from 2,820 acre-feet in 1940 to 21,300 acre-feet in 1965 . More than half of this water was used to irrigate crops (Davis and Stafford, 1966, table 1) along the Santa Cruz River from sec. 28, T. 13 S., R. 13 E., to sec. 17, T. 12 S., R 12 E. The remainder of the effluent was directly released to the Santa Cruz River near the sewage plant (pl. 1) and along the irrigated land. Between 1951 and 1965 the direct releases to the river averaged about 7,100 acre-feet per year. An annual average of 5,900 acre-feet, ranging from 2,300 to almost 9,200 acre-feet per year, was released near the plant (Davis and Stafford, 1966, fig. 3 and table 1). The amount of effluent that recharged the aquifer had to be estimated because of the problem of calculating the amount of recharge from streamflow infiltration in the same place. Recharge of 50 percent of the streamflow infiltration and 80 percent of the discharged effluent was required to balance inflow, outflow, and water-level declines in the analog model. The model, however, was constructed using a 15-percent storage coefficient, whereas the correct coefficient in the alluvium of the Santa Cruz River probably is closer to 25 percent. If the storage coefficient were increased in the model, larger percentages of the sewage effluent and infiltrated streamflow would be required to balance the model. Because losses, particularly to evapotranspiration, of effluent and streamflow are negligible to 
small, a very large percentage of the sewage effluent that is discharged to the river probably is recharged to the aquifer. A decrease in the dissolved-solids content of the ground water at this locality confirms the probable substantial recharge of sewage effluent (Laney, 1972). The annual recharge from sewage effluent probably is greater than 90 percent of the amount discharged into the river, which in 1965 was slightly less than 9,200 acre-feet. The sewage effluent returned to the aquifer in 1965 is taken as 8,300 acre-feet in the "Budget Summary" of this report.

No recharge accruing from return of industrial pumpage was needed to balance the analog-model analysis primarily because industrial pumpage was relatively small and widely dispersed prior to 1965. However, data presented by Gilkey and Beckman (1963, p. $27,40,42,49)$, which recently were corroborated by legal depositions and statements made by hydrologic consultants employed on behalf of the several operating mines, indicate that about 75 percent or perhaps more of the pumpage used for mining is returned to the ground and eventually to the aquifer as defined in this report. Most of the water is returned through the mine tailings ponds, many of which were outside of or near the boundary of the aquifer prior to 1965. Newer ponds 1 to 3 miles basinward from the aquifer boundary are now in use (pl. 1). Any return of water pumped for other industrial uses is difficult to detect by the methods used in this investigation because the amount is relatively small. Some of the water undoubtedly is returned to the aquifer, but the amount is not significant in terms of the overall budget. About 18,400 acre-feet of water, including about 12,000 acre-feet used for mining, was pumped for industrial use in 1965; the inferred return of this water to the aquifer is 9,000 acre-feet.

DISCHARGE FROM THE B.ASIN

Water is discharged from the Tucson basin by direct evaporation, transpiration by plants, streamflow, ground-water underflow from the basin at Rillito, and consumptive use of pumpage. The major discharge is through evaporation and transpiration; most of the precipitation that falls on the watershed of the Tucson basin is lost by direct evapotranspiration to the atmosphere and cannot be accounted for by ground-water storage or by measured transient flow through the basin.

Of the water that reaches the major stream channels and the ground-water reservoir, the greatest discharge is consumptive use of pumpage, followed by surface- and ground-water outflow from the basin. In recent years the computed discharge by evaporation and transpiration along the stream channels, mainly from ground 
water, has been about equivalent to the underflow out of the basin ; as ground-water development and correlative water-level declines increase, underflow, evaporation, and transpiration losses will become smaller.

STREAMFLOW

Streamflow leaves the basin only in the Santa Cruz River at Rillito, and the flow there is computed from the measured record at Cortaro, which is 5.5 miles upstream. The average annual measured discharge past Cortaro was 19,890 acre-feet for the 22 years of record in 1939-65; the discharge ranged from 1,880 acre-feet in 1956 to 67,390 acre-feet in 1955 , and the standard deviation of annual discharge was 15,320 acre-feet (Condes de la Torre, 1970). The computed annual average discharge at Rillito for the period $1936-63$ was about 17,100 acre-feet, which is rounded to 17,000 in the "Budget Summary."

\section{UNDERFLOW}

Ground water also moves out of the Tucson basin only at Rillito, but the cross section of aquifer through which ground water passes is wider and deeper than the channel of the Santa Cruz River. The underflow leaving the Tucson basin at Rillito cannot be measured directly and is estimated on the basis of the waterlevel gradient and the cross-sectional area and permeability of the aquifer through which the ground water moves. The configuration of the base of the aquifer was determined by a surface gravity survey and was confirmed by well (D-12-12) $5 \mathrm{cbc}$ (pl. 1), which penetrated the deepest part of the aquifer. The well penetrated 430 feet of sediment and bottomed in volcanic rocks correlative with Brown's (1939) upper andesite, which crops out adjacent to the Santa Cruz River at Rillito (Bikerman and Damon, 1966, p. 1226, 1229). The water-level contours in this area indicate that nearly all the flow is confined to a cross section between the hills south of the Santa Cruz River and the outcrop of quartzite 2 miles north of the river (pl. 1). Superposing the water-level contours on contours of the base of the aquifer shows that the saturated cross-sectional area is roughly equivalent to a rectangle 12,000 feet wide and 200 feet high; the rectangular area is $2,400,000$ square feet. The water-level gradient into the cross-sectional area was about 100 feet per 12,000 feet in 1966 (pl. 1). The permeability of the aquifer was estimated; an aquifer test in one well along the section gave a permeability of $450 \mathrm{gpd}$ per sq $\mathrm{ft}$, and aquifer tests in other nearby wells to the east gave permeability values two or three times greater. If the average permeability is $450 \mathrm{gpd}$ per sq $\mathrm{ft}$, the computed outflow is about 10,000 acre-feet per year, 
which probably is a reasonable approximation of the underflow out of the basin in the early 1960's. The outflow will decrease as water levels decline, because of a decrease in cross-sectional area and a decrease in the gradient into the cross section.

\section{NATURAL EVAPOTRANSPIRATION LOSSES}

Evaporation and transpiration losses of most significance to this study are from stored ground water, infiltrated streamflow, and surface flow. The discussion in this section is limited to natural losses and excepts evapotranspiration losses related to consumptive use of pumpage. Because of ground-water withdrawal and concurrent water-level declines, the evapotranspiration losses from ground water are not large and have decreased steadily since the late 1800's; these losses can be expected to decrease even more as water levels decline. However, infiltrated streamflow that might otherwise complement stored ground water evaporates or is transpired by plants. Direct evaporation from streamflow is not a significant item in the basin water budget because flow is infrequent and precipitation on the flowing-water surface tends to balance the loss to evaporation (Burkham, 1970). At the present time (1970), a moderately dense to light cover of mesquite and other phreatophytes is growing along some reaches of the Santa Cruz River and its tributaries.

The areal distribution and density of phreatophytes were mapped and estimated from a low-flying aircraft. An equivalent area with 90 to 100 percent plant-cover density was determined from the actual area and density in order to calculate water use by the plants. The aircraft estimates of plant cover probably are high in terms of both area and density. In most areas of phreatophytes the water table is 25 to about 100 feet below the land surface (pl. 4A), and the plants probably obtain moisture from rainfall and streamflow infiltration rather than from ground water in storage. However, the depth to water is less than 25 feet below the land surface in about 2,000 acres along Rillito, Tanque Verde, and Sabino Creeks and Agua Caliente Wash, where the phreatophytic growth is dense; plants in these areas probably draw much of their moisture from ground water.

The maximum annual water use by phreatophytes is estimated to be about 3.5 acre-feet per acre of dense growth (Robinson, 1958, p. 39). About 1 acre-foot of this demand is met by precipitation and infiltrated surface runoff ; therefore, the annual water demand on ground water and (or) streamflow infiltration is calculated to be 2.5 acre-feet per acre. The Santa Cruz River flood plain contains about 1,650 acres of light to dense phreatophytic vegetation, which is equivalent to about 975 acres of dense growth. 
The annual water use by plants is about 2,440 acre-feet; most of the moisture probably is intercepted from infiltration because the depth to water ranges from 25 to 100 feet below the land surface (pl. $4 A$ ), which is beyond reach of most of the plant roots. About 6,000 acres of light to dense growth is present along Rillito and Tanque Verde Creeks and their tributaries-Agua Caliente Wash, Sabino Creek, and Ventana Canyon (pl. 1) - which is estimated to be equivalent to about 5,000 acres of dense growth. The estimated annual water demand on ground water and infiltrated streamflow is about 12,500 acre-feet. About 240 acres of dense growth is present along Rincon Creek and Pantano Wash, and the estimated annual demand on infiltrated streamflow is about 600 acre-feet.

The estimated annual depletion from ground water and (or) infiltrated streamflow by about 6,000 acres of dense phreatophytes probably is no greater than 15,540 acre-feet even in wet years and may be as low as 6,000 acre-feet in dry years. As water levels decline, the loss to evapotranspiration will decrease.

\section{CONSUMPTIVE USE OF PUMPED GROUND WATER}

Much of the ground water that is withdrawn by pumping is lost to the atmosphere through evaporation and transpiration. The greatest loss in relation to pumpage is from water used for irrigation, and the smallest relative loss at this time is from water used for industrial purposes. As budgeted by the analog model, the loss of irrigation water ranges from about 74 percent to essentially all the volume pumped. About 50 percent of the water used in 1965 for industrial purposes is lost, and about 60 percent of the water pumped for public supply in the urban area is lost at the first point of use. The amount of pumpage lost to the atmosphere, particularly irrigation pumpage, was determined by analog-model analysis and is based mainly on a model fit. The accuracy of the volumes computed and estimated is dependent primarily on the accuracy of recorded pumpage and on the accuracy with which the analog model simulates the actual system.

According to the analog-model analysis, most of the water applied to irrigated fields has been consumptively used, although, prior to 1958, a 25-percent return of water pumped for irrigation was required to balance the analog model (Anderson, 1972). In 1958-65 the analog model required no return of irrigation water to simulate actual water-level declines in irrigated areas; therefore, the entire amount of pumpage in those years was assumed to have been consumptively used. Annual pumpage for irrigation averaged about 91,000 acre-feet in 1961-69 and was about 104,100 acre-feet in 1965. 
Pumpage for industrial purposes increased markedly from 1940 to 1965 ; from about 1958 to 1965 the increase was largely due to increased use of water for mining purposes. Pumpage for mining was about 12,000 acre-feet in 1965 . The total industrial pumpage in 1965 was about 18,400 acre-feet; owing to return of water to the aquifer, mainly through the mine tailings ponds, the estimated consumptive use was 9,400 acre-feet.

About $1 / 2$ to $3 / 4$, of the water pumped for public supply in the urban area is consumptively used, but in recent years about 40 percent of this water has been discharged from the sewage plant; the subsequent use and recharge of the sewage effluent is discussed in the section entitled "Irrigation and Sewage Return Water." About 54,200 acre-feet of water was pumped for public supply in 1965.

\section{BUDGET SUMMARY}

The water budget for the Tucson basin was estimated to give approximate figures for inflow and outflow in the early 1960's. The budget is a reasonable approximation of the volumes of water that flowed through and were used within the basin; it is clear that the natural variability in infiltrated streamflow and the man-caused variability in other items of the budget can significantly alter several items of inflow and outflow in the mean annual budget. The mean annual natural recharge to the aquifer is about 100,000 acre-feet and may range from about 70,000 to 150,000 acre-feet. The outflow from the aquifer in 1965 was about 185,000 acre-feet. The annual water budget, in acre-feet per year, is on page 73 .

\section{SUMMARY}

The principal source of water in the Tucson basin is the groundwater reservoir, which is recharged mainly by infiltration of streamflow along the main streams and the basin perimeter. The basin is a 1,000-square-mile area that receives only about 12 inches of precipitation annually, and because the climate is hot and dry, most of the precipitation evaporates or is transpired by plants. The area is drained by the Santa Cruz River and its tributaries, but the mean annual flows of 10,000 to 20,000 acre-feet occur mainly in 3-day-long flood events that are too intermittent to constitute a reliable water supply. The 1965 pumpage was about 177,000 acre-feet, all of which was pumped from the extensive aquifer that underlies the basin. About 3.3 million acre-feet of water was pumped from the aquifer in 1940-65. The water-level declines in the areas of large withdrawals were about 20 to 70 feet from 1940 to 1966, and the average decline ranged from 1 to 4 feet per year. 
Annual water budget

\begin{tabular}{|c|c|c|}
\hline & $\begin{array}{l}\text { Annual mean, } \\
1936-63 \\
\text { except as noted) }\end{array}$ & $\begin{array}{c}\text { Range. } \\
1936-63 \\
\text { (except as noted) }\end{array}$ \\
\hline \multicolumn{3}{|l|}{ Streamflow } \\
\hline Inflow...... & 68,000 & $25,900-167,000$ \\
\hline \multicolumn{3}{|l|}{ Outflow } \\
\hline 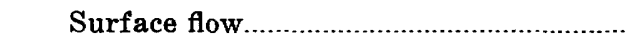 & 17,000 & $1,900-67,000$ \\
\hline Infiltration..... & 51,000 & $24,000-100,000$ \\
\hline Total & $\overline{68,000}$ & \\
\hline \multicolumn{3}{|l|}{ Aquifer } \\
\hline \multicolumn{3}{|l|}{ Inflow } \\
\hline 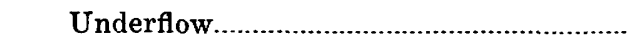 & 17,800 & ..................... \\
\hline Perimeter (mountain front) recharge.... & 31,000 & .................. \\
\hline Infiltration & 51,000 & $24,000-100,000$ \\
\hline Irrigation return & 10 & $0-35,500$ \\
\hline Sewage-effluent return & 28,300 & ................ \\
\hline Industrial return & 29,000 & ................ \\
\hline Total & 117,100 & \\
\hline \multicolumn{3}{|l|}{ Outflow } \\
\hline 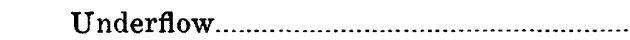 & 110,000 & ………....... \\
\hline Evapotranspiration & 115,500 & $6,000-15,500$ \\
\hline $\begin{array}{l}\text { Irrigation, public supply, and industrial } \\
\text { pumpage }\end{array}$ & 2176,700 & $1139,500-176,700$ \\
\hline Total & 2202,200 & $1155,500-202,200$ \\
\hline Inflow-outflow (storage depletion) & $\ldots \overline{2-85,100}$ & ................. \\
\hline
\end{tabular}

1Applicable to early 1960's.

${ }^{2}$ Applicable only to 1965 .

The aquifer comprises the Pantano Formation, Tinaja beds, Fort Lowell Formation, and, in places, the surficial deposits that underlie the flood plains and channels of the major streams. The units are loosely consolidated to strongly cemented and have an aggregate thickness of more than 2,000 feet. In much of the basin the units are silty sand to sandy gravel; in the downfaulted southcentral part of the basin and in a small area in the northern part, the sediment at depths greater than about 500 feet is clayey silt to mudstone.

In the northeastern part of the basin the water in the upper part of the aquifer contains less than $300 \mathrm{mg} / \mathrm{l}$ dissolved solids and is moderately hard; in the southwestern part of the basin the water contains as much as $500 \mathrm{mg} / \mathrm{l}$ dissolved solids and is hard. The dissolved solids are principally calcium, sodium, and bicarbonate, except along the stream courses and in a linear zone that extends northwest across the basin, where anomalously large concentrations of calcium, sodium, sulfate, chloride, and fluoride are present. The anomalous concentrations of calcium along the 
stream courses are associated with the infiltration of streamflow; anomalous amounts of the other dissolved solids, including sodium and other ions, are added to shallow ground water by upward leakage from deep parts of the aquifer. The water in the deep part of the aquifer contains less than $500 \mathrm{mg} / \mathrm{l}$ dissolved solids where the aquifer is composed of material generally coarser than silt, and it may contain more than $2,000 \mathrm{mg} / \mathrm{l}$ where silt or mudstone is dominant. Where the aquifer is composed of coarsegrained material at depth, the dominant dissolved solids in the water are sodium and bicarbonate, but water in the silt or mudstone facies contains large amounts of dissolved sodium, calcium, and sulfate. In much of the basin the water stored at depth contains more than $2 \mathrm{mg} / \mathrm{l}$ fluoride.

The volume of potable and recoverable ground water in storage to a depth of 500 feet below the 1966 water table was about 30.5 million acre-feet. About 2 million acre-feet or slightly less was withdrawn from storage in 1940-65. The recoverable volume of water in storage to a depth of 1,000 feet below the 1966 water table was about 52 million acre-feet; however, in parts of the basin this water contains dissolved solids in concentrations that are objectionable for public supply.

The water table is within 250 feet of the surface in most of the basin; the depth to water ranges from 25 to 100 feet below the land surface along the major streams to about 700 feet below the land surface in the eastern part of the basin. The water-level gradient slopes northwestward and is roughly parallel to the land surface; the gradient is about 100 feet per 5-10 miles in the central part of the basin and is about 100 feet per 3-4 miles in the southern and northwestern parts.

The average transmissivity of the aquifer is about $50,000 \mathrm{gpd}$ per ft. Transmissivity values range from about 1,000 to almost $500,000 \mathrm{gpd}$ per $\mathrm{ft}$. Most wells yield about 5 to $100 \mathrm{gpm}$ per foot of drawdown and are pumped at rates of $500 \mathrm{gpm}$ or more. Some wells yield as much as $4,000 \mathrm{gpm}$.

The mean annual recharge to the aquifer from all streamflow infiltration and from underflow is about 100,000 acre-feet and probably ranged from about 70,000 to about 150,000 acre-feet in 1936-63. In 1965 outflow from the aquifer was about 202,000 acre-feet, but owing to natural recharge and return of pumped water the storage depletion was about 85,000 acre-feet. The amount of storage depletion from year to year primarily is dependent on the difference between the extremely variable streamflow infiltration and the annually increasing pumpage. The mean annual storage depletion will probably increase in direct proportion to an 
increase in pumpage after 1965 . The mean annual streamflow out of the basin was about 17,000 acre-feet per year in 1936-63.

\section{REFERENCES CITED}

Anderson, T. W., 1972, Electrical-analog analysis of the hydrologic system, Tucson basin, southeastern Arizona: U.S. Geol. Survey Water-Supply Paper 1939-C, $34 \mathrm{p}$.

Bikerman, Michael, and Damon, P. E., 1966, K/Ar chronology of the Tucson Mountains, Pima County, Arizona: Geol. Soc. America Bull., v. 77, p. 1225-1234.

Brennan, D. J., 1957, Geological reconnaissance of Cienega Valley, Pima County, Arizona: Arizona Univ. unpub. Ph. D. thesis, 53 p.

Brown, S. G., Davidson, E. S., Kister, L. R., and Thomsen, B. W., 1966, Water resources of Fort Huachuca Military Reservation, southeastern Arizona: U.S. Geol. Survey Water-Supply Paper 1819-D, 57 p.

Brown, W. H., 1939, Tucson Mountains, an Arizona Basin-Range type: Geol. Soc. America Bull., v. 50, no. 5, p. 697-760.

Bull, W. B., 1961, Causes and mechanics of near-surface subsidence in western Fresno County, California, in Short papers in the geologic and hydrologic sciences: U.S. Geol. Survey Prof. Paper 424-B, p. B187-B189. 1964, Alluvial fans and near-surface subsidence in western Fresno County, California: U.S. Geol. Survey Prof. Paper 437-A, 71 p.

1968, Elastic component of aquifer-system compaction and expansion studied, in Geological Survey research 1968: U.S. Geol. Survey Prof. Paper 600-A, p. A159.

Buol, S. W., 1964, Calculated actual and potential evapotranspiration in Arizona: Arizona Univ. Agr. Expt. Sta. Tech. Bull. 162, 48 p.

Burkham, D. E., 1970, Depletion of streamflow by infiltration in the main channels of the Tucson basin, southeastern Arizona: U.S. Geol. Survey Water-Supply Paper 1939-B, $36 \mathrm{p}$.

Condes de la Torre, Alberto, 1970, Streamflow in the upper Santa Cruz River basin, Santa Cruz and Pima Counties, Arizona: U.S. Geol. Survey Water-Supply Paper 1939-A, 26 p. [1971].

Cooley, M. E., and Davidson, E. S., 1963, The Mogollon Highlands-their influence on Mesozoic and Cenozoic erosion and sedimentation: Arizona Geol. Soc. Digest, v. 6, p. 7-35.

Cooper, J. R., 1960a, Some geologic features of the Pima mining district, Pima County, Arizona: U.S. Geol. Survey Bull. 1112-C, p. 63-103.

$1960 \mathrm{~b}$, Reconnaissance map of the Willcox, Fisher Hills, Cochise, and Dos Cabezas quadrangles, Cochise and Graham Counties, Arizona: U.S. Geol. Survey Mineral Inv. Field Studies Map MF-231.

Damon, P. E., and Bikerman, Michael, 1964, Potassium-argon dating of postLaramide plutonic and volcanic rocks within the Basin and Range province of southeastern Arizona and adjacent areas: Arizona Geol. Soc. Digest, v. 7, p. 63-78.

Davidson, E. S., 1961, Facies distribution and hydrology of intermontane basin fill, Safford basin, Arizona, in Short papers in the geologic and hydrologic sciences: U.S. Geol. Survey Prof. Paper 424-C, p. C151-C153.

Davis, G. E., and Stafford, J. F., 1966, First annual report, June 1965-June 1966, Tucson Wastewater Reclamation Project: City of Tucson Water and Sewers Dept., $70 \mathrm{p}$. 
Davis, R. W., 1967, A geophysical investigation of hydrologic boundaries in the Tucson basin, Pima County: Arizona Univ. unpub. Ph. D. thesis, $64 \mathrm{p}$.

Drewes, Harald, 1966, Preliminary geologic map of the Mount Wrightson quadrangle, Santa Cruz and Pima Counties, Arizona: U.S. Geol. Survey open-file report.

1968a, Laramide orogeny, in Geological Survey research 1968: U.S. Geol. Survey Prof. Paper 600-A, p. A33.

$1968 \mathrm{~b}$, New and revised stratigraphic names in the Santa Rita Mountains of southeastern Arizona: U.S. Geol. Survey Bull. 1274-C, 15 p.

1968c, Preliminary geologic map of the Sahuarita quadrangle, Pima County, Arizona: U.S. Geol. Survey open-file map.

Drewes, Harald, and Finnell, T. L., 1968, Mesozoic stratigraphy and Laramide tectonics of part of the Santa Rita and Empire Mountains southeast of Tucson, Arizona, in Arizona Geol. Soc. Southern Arizona Guidebook 3, Tucson, 1968: p. 315-324.

DuBois, R. L., 1959, Geology of the Santa Catalina Mountains, in Arizona Geol. Soc. Southern Arizona Guidebook 2, Tucson, 1959: p. 107-116.

Evernden, J. F., Savage, D. E., Curtis, G. H., and James, G. T., 1964, Potassium-argon dates and the Cenozoic mammalian chronology of North America: Am. Jour. Sci., v. 262, p. 145-198.

Fair, C. L., and Jinks, J. E., 1961, Santa Catalina foothills fault in the Pontatoc area: Arizona Geol. Soc. Digest, v. 4, p. 131-132.

Finnell, T. L., 1970, Pantano Formation, in Cohee, G. V., Bates, R. G., and Wright, W. B., Changes in stratigraphic nomenclature by the U.S. Geological Survey, 1968: U.S. Geol. Survey Bull. 1294-A, p. A35-A36.

Gabrysch, R. K., 1967, Development of ground water in the Houston district, Texas, 1961-65: U.S. Geol. Survey open-file report, 53 p.

Geological Society of London, 1964, The Phanerozoic time-scale; a symposium: Geol. Soc. London Quart. Jour., v. 120, supp., p. 260-262.

Gilkey, M. M., and Beckman, R. T., 1963, Water requirements and uses in Arizona mineral industries: U.S. Bur. Mines Inf. Circ. 8162, $97 \mathrm{p}$.

Green, C. R., and Sellers, W. D., eds., 1964, Arizona climate: Arizona Univ. Press, $503 \mathrm{p}$.

Hardt, W. F., and Cattany, R. E., 1965, Description and analysis of the geohydrologic system in western Pinal County, Arizona: U.S. Geol. Survey open-file report, $92 \mathrm{p}$.

Hastings, J. R., 1958, Vegetation changes and arroyo cutting in southeastern Arizona during the past century-An historical review: Tucson, Arizona Univ., Desert Lands Colloquia, p. 24-39.

Hay, R. L., 1966, Zeolites and zeolitic reactions in sedimentary rocks: Geol. Soc. America Spec. Paper 85, 130 p.

Hayes, P. T., and Drewes, Harald, 1968, Mesozoic sedimentary and volcanic rocks of southeastern Arizona, in Arizona Geol. Soc. Southern Arizona Guidebook 3, Tucson, 1968: p. 49-58.

Heindl, L. A., 1959, Geology of the San Xavier Indian Reservation, Arizona, in Arizona Geol. Soc. Southern Arizona Guidebook 2, Tucson, 1959: p. 153-159.

Heindl, L. A., Cosner, O. J., Page, H. G., Armstrong, C. A., and Kister, L. R., 1962, Summary of ground water on the Papago Indian Reservation, Arizona: U.S. Geol. Survey Hydrol. Inv. Atlas HA-55, 1 sheet.

Holmes, Arthur, 1964, Principles of physical geology: New York, Ronald Press. 
Johnson, A. I., 1966, Specific yield-compilation of specific yields for various materials: U.S. Geol. Survey open-file report, 119 p.

Kinnison, J. E., 1958, Geology and ore deposits of the southern section of the Amole mining district, Tucson Mountains, Arizona: Arizona Univ. unpub. M.S. thesis, 123 p.

1959a, Structure of the Saginaw area, Tucson Mountains, Arizona, in Arizona Geol. Soc. Southern Arizona Guidebook 2, Tucson, 1959: p. 146-151.

1959b, Chaotic breccias in the Tucson Mountains, Arizona, in Arizona Geol. Soc. Southern Arizona Guidebook 2, Tucson, 1959: p. 49-57.

Knechtel, M. M., 1938, Geology and ground-water resources of the valley of the Gila River and San Simon Creek, Graham County, Arizona, with a section on the Chemical character of the ground water, by $\mathrm{E}$. W. Lohr: U.S. Geol. Survey Water-Supply Paper 796-F, p. 181-222.

Lacy, W. C., 1964, Geological causes of foundation failures in the area of Tucson, Arizona: Soc. Mining Engineers Trans., v. 229, p. 40-44.

Lance, J. F., 1958, Pleistocene capybara from Arizona [abs.]: Geol. Soc. America Bull., v. 69, no. 12, pt. 2, p. 1693-1694.

1960 , Stratigraphic and structural position of Cenozoic fossil localities in Arizona: Arizona Geol. Soc. Digest, v. 3, p. 155-160.

Laney, R. L., 1972, Chemical quality of the water in the Tucson basin, Arizona: U.S. Geol. Survey Water-Supply Paper 1939-D, 46 p.

Lofgren, B. E., and Klausing, R. L., 1967, Land subsidence due to groundwater withdrawal, Tulare-Wasco area, California: U.S. Geol. Survey open-file report, $307 \mathrm{p}$.

Matlock, W. G., Schwalen, H. C., and Shaw, R. J., 1965, Progress report on study of water in the Santa Cruz Valley, Arizona: Arizona Univ., Agr. Expt. Sta. Rept. 233, 55 p.

McColly, R. A., 1961, The geology of the western portion of the Saguaro National Monument: Arizona Geol. Soc. Digest, v. 4, p. 87-92.

Montgomery, E. L., 1963, The geology and ground water investigation of the Tres Alamos damsite area of the San Pedro River, Cochise County, Arizona: Arizona Univ., unpub. M.S. thesis, $61 \mathrm{p}$.

Pashley, E. F., Jr., 1961, Subsidence cracks in alluvium near Casa Grande, Arizona: Arizona Geol. Soc. Digest, v. 4, p. 95-101.

1964, Folds in the Tanque Verde, Rincon, and southern Santa Catalina Mountains, Pima County, Arizona [abs.]: Geol. Soc. America Spec. Paper 76, p. 289.

1966, Structure and stratigraphy of the central, northern, and eastern parts of the Tucson basin, Arizona: U.S. Geol. Survey open-file report, $273 \mathrm{p}$.

Percious, J. K., 1968, Geology and geochronology of the Del Bac Hills, Pima County, Arizona, in Arizona Geol. Soc. Southern Arizona Guidebook 3, Tucson, 1968: p. 199-207.

Peterson, R. C., 1968, A structural study of the east end of the Catalina forerange, Pima County, Arizona: Arizona Univ. unpub. Ph. D. thesis, $105 \mathrm{p}$.

Platt, W. S., 1963, Land-surface subsidence in the Tucson area: Arizona Univ. unpub. M.S. thesis, $38 \mathrm{p}$.

Poole, F. G., Baars, D. L., Drewes, Harald, Hayes, P. T., Ketner, K. B., McKee, E. D., Teichert, Curt, and Williams, J. S., 1967, Devonian of the Southwestern United States, in Oswald, D. H., ed., International symposium on the Devonian System, Calgary, Alberta, September 1967: Calgary, Alberta Soc. Petroleum Geologists, v. 1, p. 879-912. 
Robinson, T. W., 1958, Phreatophytes: U.S. Geol. Survey Water-Supply Paper $1423,84 \mathrm{p}$.

Schumann, H. H., and Poland, J. F., 1970, Land subsidence, earth fissures, and ground-water withdrawal in south-central Arizona, U.S.A.: Tokyo, Internat. Symposium on Land Subsidence, v. 1, no. 88, September 1969, p. 295-302.

Schwalen, H. C., 1942, Rainfall and runoff in the upper Santa Cruz River drainage basin: Arizona Univ. Agr. Expt. Sta. Tech. Bull. 95, p. 421-472.

Schwalen, H. C., and Shaw, R. J., 1957, Ground water supplies of the Santa Cruz Valley of southern Arizona between Rillito Station and the international boundary: Arizona Univ. Agr. Expt. Sta. Bull. 288, 119 p.

1961, Progress report on study of water in the Santa Cruz Valley, Arizona: Arizona Univ. Agr. Expt. Sta. Rept. 205, 39 p.

Sherman, J. E., and Hatheway, A. W., 1964, Occurrence of linears in the Tucson south quadrangle, Pima County, Arizona: Arizona Geol. Soc. Digest, v. 7, p. 79-86.

Smith, G. E. P., 1910, Ground water supply and irrigation in the Rillito Valley, Arizona: Arizona Univ. Agr. Expt. Sta. Bull. 64, 244 p.

1938, The physiography of Arizona valleys and the occurrence of ground water: Arizona Univ. Agr. Expt. Sta. Tech. Bull. 77, 91 p.

Taylor, O. J., 1960, Correlation of volcanic rocks in Santa Cruz County, Arizona: Arizona Geol. Soc. Digest, v. 3, p. 87-91.

Thornthwaite, C. W., 1948, An approach toward a rational classification of climate: Geog. Rev., v. 38, no. 1, p. 55-94.

Tolman, C. F., 1909, Geology of Tumamoc Hills: Carnegie Inst. Wash. Pub. 113, p. 67-82.

Turner, S. F., and others, 1943, Ground-water resources of the Santa Cruz basin, Arizona: U.S. Geol. Survey open-file report, $84 \mathrm{p}$.

U.S. Public Health Service, 1962, Drinking water standards: U.S. Public Health Service Pub. 956, 61 p.

Voelger, Klaus, 1953, Cenozoic deposits in the southern foothills of the Santa Catalina Mountains near Tucson, Arizona: Arizona Univ. unpub. M.S. thesis, $101 \mathrm{p}$.

Wilson, E. D., Moore, R. T., and O'Haire, R. T., 1960, Geologic map of Pima and Santa Cruz Counties, Arizona: Arizona Univ., Arizona Bur. Mines.

Wilson, L. G., and DeCook, K. J., 1968, Field observations on changes in the subsurface water regime during influent seepage in the Santa Cruz River: Water Resources Research, v. 4, no. 6, p. 1219-1234.

Wood, P. A., 1960, Paleontological investigations in the 111 Ranch area: Arizona Geol. Soc. Digest, v. 3, p. 141-143. 


\section{INDEX}

[Italic page numbers indicate major reference]

A, B

Acknowledgments

Age, Fort Lowell Formation

Helmet Fanglomerate.

Tinaja beds

Agua Caliente Wash.

Alluvium. See Surficial deposits.

Aquifer

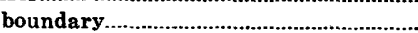

compaction

effective base.

recharge. See Recharge.

specific yield

Big Wash

Black Mountain

Page

Caliche.

Canada del Oro

Cementation 60,63

Cemetery terrace

Chąnges, manmade

Chemical quality. See Ground water; Streamfiow.

Clay minerals

Climate.

Coefficient of storage

Compaction

Cores.

Fort Lowell Formation

Pantano Formation

Correlation, Fort Lowell Formation

Pantano Formation.

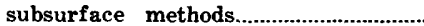

Tinaja beds

Cortaro area

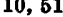

\section{$\mathbf{D}, \mathbf{E}$}

Davidson Canyon.

17,19

Definitions

Discharge as outflow

$4,12,45,49$

Drainage patterns.

Drill cuttings.

Drill holes

Electrical-analog model.

Environment of deposition, Fort Lowell Formation.

Tinaja beds.

Environmental changes, man made........... 10, 51

Equilibrium condition

Evapotranspiration.

$10,11,70$

\section{$\mathbf{F}$}

Page

Facies changes...................................E22, 23, 29, 33

Faults................................................... 21, 28 anomalous chemical concentrations.... 58 basin uplift.............................................. 35 basis of inference................................... 33 cause.................................................... 36 effect on wells......................................... 43, 57 relation to ground-water levels............ 43 relation to subsidence............................... $\quad 54$ relation to water-table gradient........... 44 Santa Cruz.......................... 21, 22, 35, 47, 54 Tucson-Rillito........................................... 34

Fault blocks......................................... 21

Fieldwork.......................................................... 6

Fissures...................................................... 51

Floods.......................................................... 55, 57

Fort Lowell Formation.................................. 25

age........................................................ 27

basal contact............................................. 28 cores

correlation................................................... 27

deposition center.................................... $\quad 29$

drainage..................................................... 35

environment of deposition.................... $\quad 29$

facies changes............. 29

hydrologic significance........................... $\mathbf{3 0}$

lithology............................................. 29

permeability ............................................... 30

porosity..................................................... 30

subsurface contacts................................. 28

thickness................................................... 27

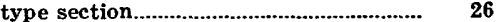

uplift of basin...........................................

upper contact............................................. $\quad 28$

water quality............................................. 30

wells......................................................... 30

G

Geographic setting...................................... 2, 4

Gravity data ................................................. $\quad 36$

Ground water, anomalous characteristics.. $\quad 34$

pumpage................................................ 37,71

quality. $50,56,73$

anomalies....................................... 58

calcium ..................................... 58

chloride............................................. 58

crystalline rocks................................ 14

dissolved solids................................. 57

fiuoride................................................ 58

Fort Lowell Formation................... $\quad 30$

Mesozoic rocks.................................. 15

nitrate............................................ 58

Paleozoic rocks.................................... 15

Pantano Formation......................... 19 
Ground water-Continued

Pantano Wash

Page quality-Continued

temperature

Tinaja beds

volcanic rocks

relation to evapotranspiration............... suitability for use...

underflow

water-level declines

rate.

relation to evapotranspiration.... relation to irrigation return. relation to land subsidence.

$$
\text { H, I, J }
$$

Helmet Fanglomerate

Hydraulic head..

Hydrologic system

16,17

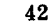

9,72

Industrial return water

Industrial use

Infiow. method of calculation rate...

Irrigation nitrate. return water.

Jaynes terrace

\section{L, M, O}

Land subsidence cause. potential.

Lithology, alluvium...

Fort Lowell Formation

Pantano Formation.

Tinaja beds.

Logs of wells.

Manmade changes

10,51

Manmade structures, damage.

Management of water resources.

Methods of analysis.

Mountains.

$4,13,61$

Outflow method of calculation

Pantano Formation

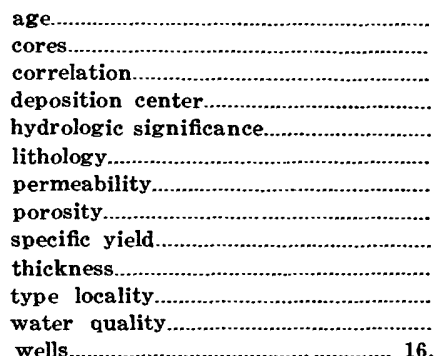

wells.

$16,18,19$ comparable studied areas

Permeability, definition................................. 12

Fort Lowell Formation.................... 30

Pantano Formation................................. 19

Tinaja beds............................................... 24

Phreatophytes................................................... 70

Population ........................................................ 40

Porosity, aquifer.......................................... 49

definition.................................................. 12

Fort Lowell Formation.........................

Pantano Formation................................ 19

Tinaja beds................................................ 24

Precipitation................................. 10

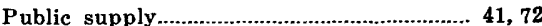

Pumpage..................................................... 37

consumptive use................................... 37, 71

distribution

errors in estimates................................ 38

irrigation ................................................... 41

Tucson urban area................................. $\quad 40$

Purpose of report..................................... 5

Purpose of study............................................. 3

Q, R

Quality of water. See Ground water; Streamflow.

Recharge

along aquifer perimeter...................... 61 relation to irrigation return water.... 66 relation to streamflow infiltration $42,62,65$

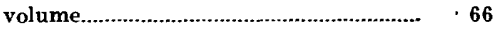
Rillito 69

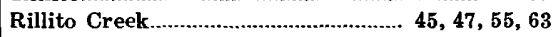
Rillito surface............................................... 25 Rincon Creek............................................. 55, 63

Rincon Mountains........................................ 14, 34

Rock units, differentiation........... 12 functions............................................. 11, 12

Mesozoic..................................................... 15

mountains............................................ 13

Paleozoic............................................... 15

sedimentary.............................................. 14

variations........................................... 12

volcanic ........... 14

See also Sedimentary units.

\section{$\mathbf{S}$}

15,16

17

17,18

16

19

16

18

19

19

19

17

16

19
Sabino Creek........................................... 55, 63

Safford basin............................................ 27

Sahuarita area ........................................ 41, 47, 53

San Pedro Valley........................................... 27

San Xavier conglomerate beds...................... 16

Santa Catalina Mountains............................. 14

Santa Cruz fault....................... 21, 22, 35, 47, 54

Santa Cruz River.......................... 41, 45, 47, 53, 55

Cortaro............................................... 41, 69

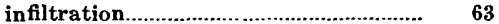

Rillito....................................................... 69

Sahuarita................................... 41, 47, 53

underflow recharge................................... 60

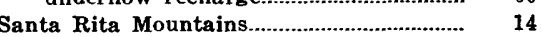


Page

Sedimentary units

aquifer.

differentiation

structure

thickness

See also Rock units.

Sewage effiuent

Sierrita Mountains

Soils

Specific capacities.

Specific yield, alluvium

anomalies

aquifer.

Pantano Formation.

Tucson urban area

Springs

Steady-state condition

Storage

depletion

method of calculation

surface reservoirs.

volume recoverable

Storage coefficient

Storms.

Streamflow

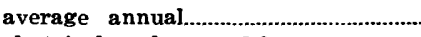

electrical-analog model.............................

frequency.

impoundment.

infiltration

method of calculation.

rate.

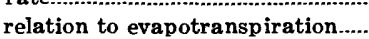

relation to recharge. volume.

42,6

outfiow

quality.

rate.

sediment load

suitability for use.

supply value.

variability

Structural geology.

depression of basin

faults. See Faults.

uplift of basin.

Subsidence. See Land subsidence.

Subsurface contacts.

Summary

Surficial deposits

alluvium, lithology

specific yield

transmissivity.

hydrologic significance

thickness

\section{$\mathbf{T}$}

Tanque Verde Creek

Temperature, air

ground water.
63,64

56,59

15

33

28,52

$4,30,45$

11,62
Page

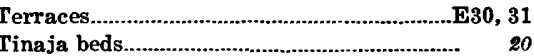

age $\quad 21$

correlation................................................ 20

deposition center...................................... 21, 22

environment of deposition..................... 22, 23

facies, coarse-grained............................ 22 distribution...................................... 22

fine-grained....................................... 23

hydraulic head........................................ 42

hydrologic significance............................ $\quad 24$

lithology................................................... 22

permeability................................................ 24

porosity...................................................... 24

thickness............................................ 23

transmissivity ............................................ 24, 47

water quality ............................................. $\quad 25$

wells.................................................... 24

Transmissivity................................................ 44, 74

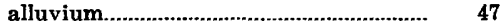

relation to ground-water movement.... $\quad \mathbf{4 5}$

relation to water-table gradient.......... $\quad \mathbf{4 4}$

reliability of model................................. 46

Tinaja beds............................................ 24, 47

Tueson Mountains.................................. 13, 14, 17

Tucson-Rillito fault...................................... 34

Tucson urban area....................................... 40, 41

\section{$\mathrm{U}, \mathrm{V}, \mathbf{w}$}

Underflow, discharge................. 69

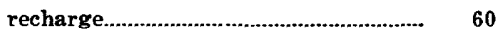

University terrace............................ 28, 30,31, 52

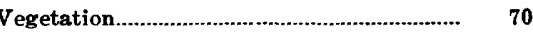

Water budget....................................... 10, 59,73

Water-level declines. See Ground water.

Water quality. See Ground water ; Streamfiow.

Water table

$10,44,74$

Water use

industrial................................................. 72

irrigation.......................................... 41, 71

public supply....................................40,41, 72

Santa Cruz River.................................... 41

Tucson urban area........................... 40, 41, 72

Wells, crystalline rocks................................ 13 deep........................................................ 18

Fort Lowell Formation.......................... 30

hydraulic head........................................... 42

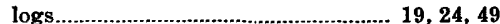

Mesozoic rocks............................................. 15

near faults............................................. 43, 57

numbering system................................... 7

Pantano Formation.......................... 16, 18, 19

specific capacities....................... 19, 24, 30, 45

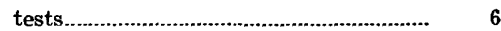

Tinaja beds............................................... 24

voleanic rocks............................................ 14

yields......................................................... 19, 24 


\section{Water Resources of the Tucson Basin}

GEOLOGICAL SURVEY WATER-SUPPLY PAPER 1939

This volume was printed as separate chapters $A-E$

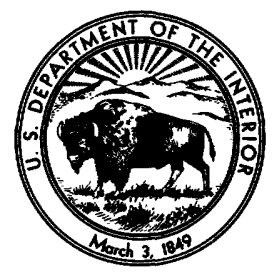


UNITED STATES DEPARTMENT OF THE INTERIOR

ROGERS C. B. MORTON, Secretary

GEOLOGICAL SURVEY

V. E. McKelvey, Director 


\section{CONTENTS}

\section{[Letters designate the separately published chapters]}

(A) Streamflow in the upper Santa Cruz River basin, Santa Cruz and Pima Counties, Arizona, by Alberto Condes de la Torre.

(B) Depletion of streamflow by infiltration in the main channels of the Tucson basin, southeastern Arizona, by D. E. Burkham.

(C) Electrical-analog analysis of the hydrologic system, Tucson basin, southeastern Arizona, by T. W. Anderson.

(D) Chemical quality of the water in the Tucson basin, Arizona, by R. L. Laney.

(E) Geohydrology and water resources of the Tucson basin, Arizona, by E. S. Davidson. 